\title{
PLANKTIC FORAMINIFERAL SPECIES TURNOVER ACROSS DEEP-SEA APTIAN/ ALBIAN BOUNDARY SECTIONS
}

\author{
Brian T. Huber ${ }^{1,3}$ AND R. MARK LeCKIE ${ }^{2}$
}

\begin{abstract}
A major planktic foraminiferal species turnover accompanied by a dramatic reduction in shell size, a fundamental change in shell architecture, and a precipitous drop in the abundance of planktic relative to benthic species occurs across the Aptian/Albian boundary interval (AABI) at globally distributed deep-sea sections. Extinction of the large and distinctive planktic foraminifer Paraticinella eubejaouaensis, used to denote a level at or near the Aptian/ Albian boundary, coincides with the extinctions of relatively long-ranging Aptian species of Hedbergella and Globigerinelloides. At Deep Sea Drilling Project (DSDP) Site 511 (southern South Atlantic), which is the most complete and best preserved of the studied AABI sections, the Aptian assemblage is of low diversity and species are replaced by initially one and then two very small, smooth-surfaced, thinwalled species of Microhedbergella $\mathrm{n}$. gen. The oldest species of this genus, Mi. miniglobularis n. sp., probably descended from Hedbergella praelippa $\mathrm{n}$. sp. and is the nominate taxon for a new lowermost Albian interval zone and is considered ancestral to several small, gradually evolving microperforate species, including Mi. praeplanispira n. sp., Mi. pseudoplanispira n.sp., and Mi. pseudodelrioensis n. sp., which range into the middle and upper Albian. The small hedbergellids that characterize the Mi. miniglobularis Interval Zone at Site 511 have also been identified from samples taken just above the Kilian black shale level in the Vocontian Basin of southeast France. The Albian record at Site 511 reveals a gradual increase in planktic foraminifera shell size and assemblage dominance, as well as the gradual evolution during the middle Albian of species characterized by a finely perforate, pustulose test. Taxa with this shell infrastructure are included in Muricohedbergella $\mathbf{n}$. gen. A new "Ticinella yezoana" Partial Range Zone is erected at Site 511 for correlation of the middle-upper Albian at high latitudes.

At Ocean Drilling Program (ODP) Site 1049 (western North Atlantic), which also yields well-preserved foraminifera across the AABI, Aptian species of Hedbergella, Globigerinelloides, and Pseudoguembelitria blakenosensis n. gen., $\mathbf{n}$. sp. are replaced by lower Albian assemblages composed only of two minute species of Microhedbergella. However, this boundary section is considered incomplete because of the absence of the Mi. miniglobularis Zone. A new upper lower Albian Ti. madecassiana Zone is defined at Site 1049 for the interval between the lowest occurrence (LO) of the nominate taxon and the LO of Ti. primula, the nominate species of the middle Albian Ti. primula Zone.
\end{abstract}

\footnotetext{
${ }^{1}$ Department of Paleobiology, National Museum of Natural History, Smithsonian Institution, $10^{\text {th }}$ and Constitution Ave., Washington D.C., 20013-7012, USA

${ }^{2}$ Department of Geosciences, University of Massachusetts, $611 \mathrm{~N}$. Pleasant St., Amherst, MA 01003, USA

${ }^{3}$ Correspondence author E-mail: huberb@si.edu
}

The AABI at DSDP Site 545 (eastern North Atlantic) has a major unconformity spanning the uppermost Aptian through the upper Albian. A black shale sequence previously placed in the lower Albian and designated as Oceanic Anoxic Event 1b is now determined to be latest Aptian in age. The AABI at ODP Site 763 (southeast Indian Ocean) is also marked by an unconformity between the upper Aptian Pa. eubejouaensis Zone and the lower Albian Mi. rischi Zone. This site needs further study to resolve whether overlap of species from both zones is the result of downslope reworking or an exception to the pattern of abrupt species turnover observed at the other deep-sea sites.

The dramatic changes in planktic foraminiferal assemblages across the AABI suggest major changes in carbonate chemistry, vertical stratification, or productivity in the surface mixed layer occurred during the last $1 \mathrm{myr}$ of the Aptian. Understanding the cause or causes for these changes will require much further investigation.

\section{INTRODUCTION}

One of the largest and most significant species turnovers in the evolutionary history of planktic foraminifera occurs across the Aptian/Albian boundary (Leckie, 1989; Tornaghi and others, 1989; Premoli Silva and Sliter, 1999; Leckie and others, 2002), with a change from latest Aptian assemblages dominated by large-sized, robust, and coarsely ornamented species to early Albian assemblages comprised only of minute, nondescript, weakly calcified forms that lack ornamentation (Fig. 1). Despite the significance of this event, there is no reliable documentation of the rate and magnitude of the species extinction, the post-extinction recovery, or the associated changes in marine geochemistry across the Aptian/Albian boundary interval (AABI). The main reasons for our limited understanding of this event include inconsistent and inaccurate species identifications resulting from an inadequate taxonomic framework, widespread occurrence of Aptian/Albian unconformities, and poor preservation due to diagenetic alteration.

The primary objective of this paper is to establish a new taxonomic, phylogenetic, and biostratigraphic framework for the latest Aptian through early Albian on the basis of remarkably well-preserved planktic foraminiferal assemblages from Ocean Drilling Program (ODP) Site 1049 and Deep Sea Drilling Project (DSDP) Sites 390 and 392 (all from Blake Plateau, western North Atlantic) and DSDP Site 511 (Falkland Plateau, southern South Atlantic). Study of "glassy" (i.e., optically translucent) foraminiferal shells from these samples enables reliable characterization of shell microstructure and wall texture and development of a classification scheme that is based on the observations of stratophenetic changes in wall microstructure, wall texture, and shell morphology. Species distributions across the AABI at DSDP Site 545 (Mazagan Plateau, eastern North Atlantic) 


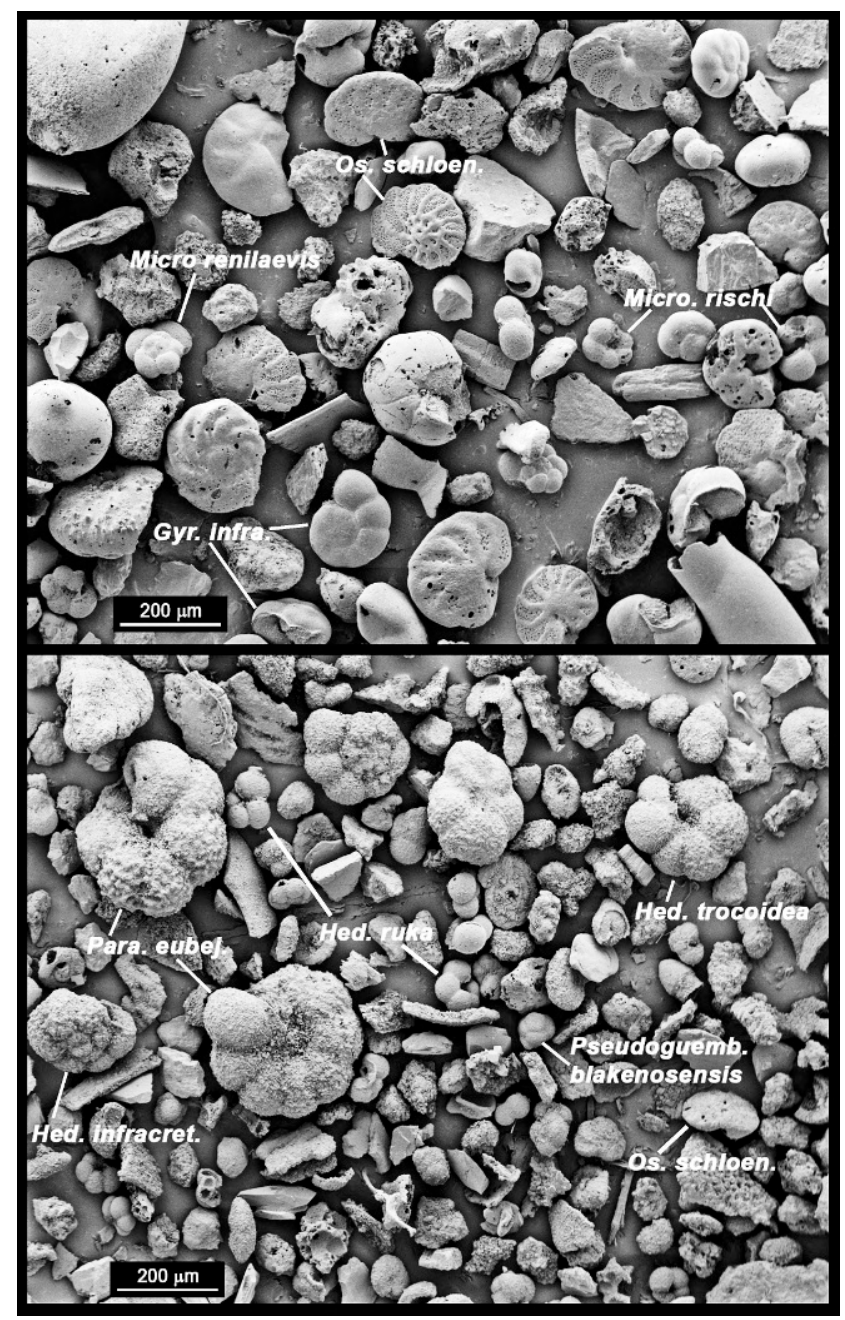

FIGURE 1. SEM micrographs comparing the $>63-\mu \mathrm{m}$ sieved residues of samples from the uppermost Aptian and lowermost Albian to show change in the size and species composition from the uppermost Aptian (1049C-12X-4, 145-146 cm; $145.26 \mathrm{mbsf}$ ) and lowermost Albian (1049C-12X-4, 140-142 cm; $145.21 \mathrm{mbsf}$ ) of ODP Hole 1049C.

and ODP Site 763 (Exmouth Plateau, southeast Indian Ocean) and the Vocontian Basin (southeastern France) were also studied to test the species distribution patterns seen at the other sites and to compare species distributions and infer stratigraphic completeness across the AABI.

\section{METHODS}

Upper Aptian and lower to middle Albian cores from Sites/Holes 1049A, 1049C, 390, 392A, 511, 545, and 763B (Fig. 2) were sampled at the Integrated Ocean Drilling Program (IODP) core repositories for biostratigraphic analysis. Sample spacing varied from 1-150 cm, depending on proximity to biomarker boundaries. Samples were soaked for 24 hours in tap water, screen-washed, and convection dried at $50^{\circ} \mathrm{C}$. Numerous planktic specimens from samples immediately above, within and below the AABI from all sections were observed with a scanning electron microscope in order to ensure accurate species identification. Presence/ absence and relative abundance observations are presented in Tables 1-4. Sample spacing ranges 1-107 cm for Site 1049

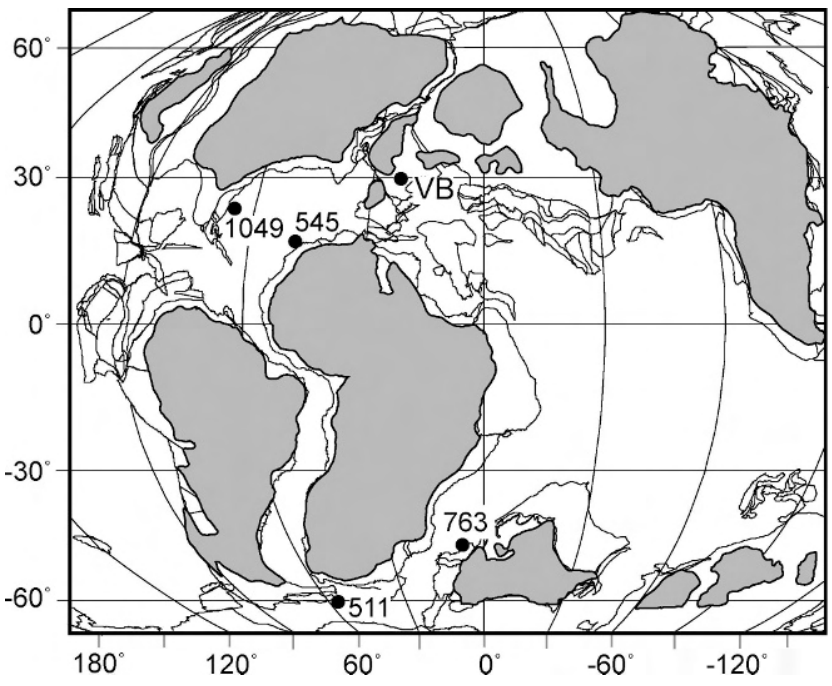

FIGURE 2. Paleogeographic reconstruction for $112 \mathrm{Ma}$ based on Hay and others (1999) showing location of Aptian/Albian boundary DSDP and ODP sites and Vocontian Basin (VB) Pré-Guittard section discussed in this study.

and 1-100 cm for DSDP Site 511. Lowest occurrences (LOs) and highest occurrence (HOs) of marker species are used to define biostratigraphic boundaries within sections.

Planktic foraminifer abundance was estimated relative to the total sieved residue and relative to the total planktic assemblage. Species abundance counts and counts of planktic versus benthic foraminifera were made on the $>63-\mu \mathrm{m}$ size fraction of samples that were divided using an Otto microsplitter with a targeted count of about 300 planktic specimens. Tests showing $>50 \%$ fragmentation were excluded from the specimen counts.

Test size changes across the AABI were obtained by measuring the maximum test diameters or lengths of 3-5 specimens for each species and then plotting the mean, maximum, and minimum values for each species in each sample.

Age estimates of stage and biozone boundaries are based on the 2004 geologic time scale of Gradstein and others (2004).

Stable isotope analyses of Albian samples from Hole 1049C were published by Erbacher and others (2001), whereas we performed the analyses on Aptian samples using a Thermo Finnegan ${ }^{\mathrm{TM}}$ DeltaPlus mass spectrometer at the Biogeochemistry Isotope Laboratory, University of Missouri. The latter data were reported relative to the Vienna Peedee belemnite (VPDB) standard after normalization based on the difference between the within-run average of NBS 19 and its recommended value $\left(\delta^{13} \mathrm{C}=-1.95 \% ; \delta^{18} \mathrm{O}=2.20 \%\right)$. Replicate measurements of NBS 19 yielded long-term precision (1 SD) better than $\pm 0.01 \%$ or for $\delta^{18} \mathrm{O}$ and $\pm 0.02 \%$ for $\delta^{13} \mathrm{C}$.

\section{APTIAN/ALBIAN BOUNDARY DEFINITION}

Because a Global Boundary Stratotype Section and Point (GSSP) for defining the base of the Albian Stage has not yet been formally accepted, criteria for identification and correlation of the AABI have not yet been established. One of the main impediments to resolving this boundary controversy is that ammonites, which have been traditionally used to define most Cretaceous stage boundaries in 
TABLE 1. Relative abundance estimates for planktic foraminiferal from upper Aptian through middle Albian and middle Campanian samples from ODP Hole 1049C. Abundances were categorized as follows: $\mathrm{A}=$ abundant $(>25 \%) ; \mathrm{C}=$ common $(10-25 \%) ; \mathrm{F}=$ few $(1-10 \%) ; \mathrm{R}=\mathrm{rare}(<1 \%) ; \mathrm{B}=$ barren (no specimens in sample). Preservation ratings: $\mathrm{E}=$ excellent (sample includes "glassy" shells with no evidence of recrystallization or secondary mineral infilling or overgrowth); $\mathrm{G}=\operatorname{good}$ ("frosty" shells with minor recrystallization, but no evidence of secondary mineral infilling or overgrowth); $\mathrm{M}=$ moderate (opaque shells with minor to significant shell recrystallization, presence of secondary mineral infilling or overgrowth); $\mathrm{P}$ $=$ poor (shells strongly recrystallized and infilled or strongly fragmented).

\begin{tabular}{|c|c|c|c|c|c|c|c|c|c|c|c|c|c|c|c|c|c|c|c|c|c|c|c|}
\hline ODP Hole 1049C & 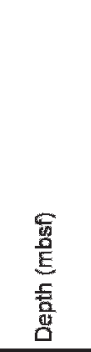 & 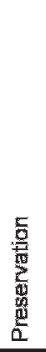 & 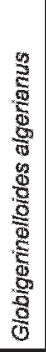 & 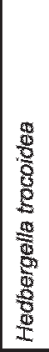 & 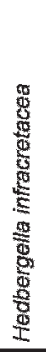 & 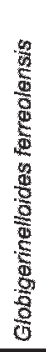 & 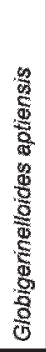 & 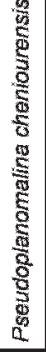 & 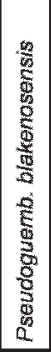 & 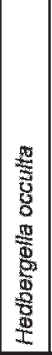 & 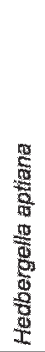 & 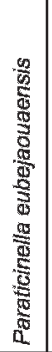 & 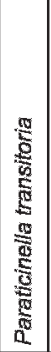 & 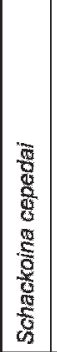 & 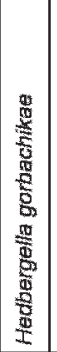 & 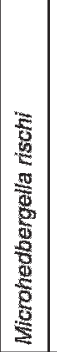 & 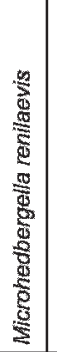 & 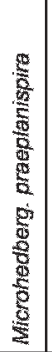 & 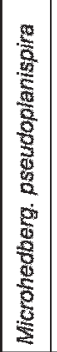 & 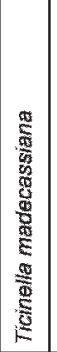 & 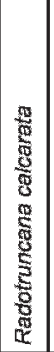 & $\begin{array}{l}\text { 鹪 } \\
\text { N }\end{array}$ & $\stackrel{g}{\mathbb{2}}$ \\
\hline $11 X-2,113-115$ & 132.31 & $\mathrm{E}$ & & & & & & & & & & & & & & & & & & & $\mathrm{R}$ & calcarata & Camp. \\
\hline $11 \mathrm{X}-2,124-126$ & 132.44 & $E$ & & & & & & & & & & & & & & $\bar{A}$ & $\mathrm{R}$ & $F$ & $\mathrm{~A}$ & $\mathrm{R}$ & & \multirow{5}{*}{ 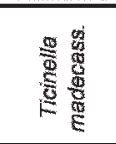 } & \multirow{14}{*}{ 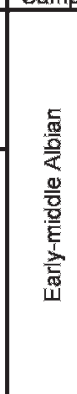 } \\
\hline $11 X-3,60-62$ & 133.30 & $E$ & & & & & & & & & & & & & & $A$ & $\mathrm{R}$ & $F$ & $\mathrm{R}$ & $\mathrm{R}$ & & & \\
\hline $11 X-4,17-19$ & 133.87 & $E$ & & & & & & & & & & & & & & A & $\mathrm{F}$ & $\mathrm{R}$ & $\mathrm{F}$ & $\mathrm{R}$ & & & \\
\hline $11 X-4,48-50$ & 134.18 & $E$ & & & & & & & & & & & & & & $\mathrm{~A}$ & $\bar{A}$ & $\mathrm{R}$ & $\mathrm{R}$ & $\mathrm{R}$ & & & \\
\hline $11 \mathrm{X}-\mathrm{CC}, 30-31$ & 134.53 & $E$ & & & & & & & & & & & & & & A & $\mathrm{A}$ & $\mathbf{R}$ & $F$ & $\mathbf{R}$ & & & \\
\hline $12 X-1,27-29$ & 139.57 & $G$ & & & & & & & & & & & & & & $\mathrm{c}$ & $\mathrm{C}$ & $\mathrm{R}$ & $\mathrm{R}$ & & & \multirow{9}{*}{ 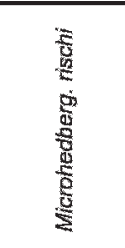 } & \\
\hline $12 X-2,27-29$ & 141.07 & $E$ & & & & & & & & & & & & & & $\mathrm{C}$ & A & & & & & & \\
\hline $12 \mathrm{X}-3,17-19$ & 142.47 & $E$ & & & & & & & & & & & & & & $\mathrm{R}$ & A & & & & & & \\
\hline $12 X-4,17-19$ & 143.97 & $M$ & & & & & & & & & & & & & & A & A & & & & & & \\
\hline $12 X-4,57-59$ & 144.36 & $E$ & & & & & & & & & & & & & & $A$ & A & & & & & & \\
\hline $12 X-4,111-113$ & 144.92 & $E$ & & & & & & & & & & & & & & A & A & & & & & & \\
\hline $12 X-4,130-132$ & 145.11 & $E$ & & & & & & & & & & & & & & A & A & & & & & & \\
\hline $12 \times-4,140-142$ & 145.21 & $\mathrm{E}$ & & & $r$ & & & & & & & $\mathrm{r}$ & & & & A & A & & & & & & \\
\hline $12 X-4,145-147$ & 145.26 & $\bar{G}$ & & $r$ & $r$ & & & & $r$ & & & $r$ & $r$ & & & $\mathrm{~A}$ & C & & & & & & \\
\hline $12 X-4,149-150$ & 145.29 & $G$ & & $\mathrm{R}$ & $\bar{F}$ & & & & $\bar{F}$ & $\mathrm{R}$ & & $\bar{A}$ & $\mathrm{C}$ & & & $r$ & $r$ & & & & & \multirow{15}{*}{ 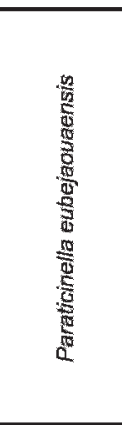 } & \multirow{23}{*}{ 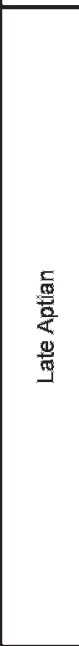 } \\
\hline $12 X-5,0-2$ & 145.33 & $M$ & & $\mathrm{~F}$ & $F$ & & $?$ & & $\mathbf{R}$ & $\mathrm{R}$ & & $\mathrm{A}$ & $\mathrm{C}$ & & $\mathrm{R}$ & & & & & & & & \\
\hline $12 X-5,17-19$ & 145.48 & $G$ & & $F$ & $F$ & & & & $\mathrm{C}$ & $F$ & & $\mathrm{C}$ & & & & & & & & & & & \\
\hline $12 x-5,20-22$ & 145.51 & $\mathrm{M}$ & & $F$ & $\mathrm{C}$ & & & & $\mathrm{A}$ & $F$ & & $\mathrm{C}$ & $\mathrm{F}$ & & & & & & & & & & \\
\hline $12 X-5,30-32$ & 145.61 & $G$ & & C & C & & $\mathrm{R}$ & & $\mathrm{C}$ & $F$ & & C & & & & & & & & & & & \\
\hline $12 \times-5,69-70$ & 145.99 & $\mathrm{G}$ & & $\mathrm{F}$ & $\mathrm{c}$ & $\mathrm{R}$ & $\mathrm{R}$ & & A & $\mathrm{c}$ & & C & & & & & & & & & & & \\
\hline $12 X-5,121-122$ & 146.51 & $G$ & & A & $\mathrm{C}$ & $\mathrm{F}$ & $\mathrm{F}$ & & $c$ & A & & C & $F$ & $\mathrm{R}$ & $\mathrm{R}$ & & & & & & & & \\
\hline $12 X-5,130-131$ & 146.60 & $\mathrm{G}$ & & $\mathrm{F}$ & $\mathrm{F}$ & A & A & & $\mathrm{F}$ & $\mathrm{c}$ & & $\mathrm{R}$ & & & & & & & & & & & \\
\hline $12 X-8,10-11$ & 146.90 & $G$ & & $F$ & $F$ & $\mathrm{C}$ & $\mathrm{C}$ & & $\mathrm{F}$ & $F$ & $F$ & $F$ & & $\mathrm{R}$ & & & & & & & & & \\
\hline $12 X-8,16-18$ & 146.96 & $\mathrm{G}$ & & A & $F$ & & & & & & & $F$ & & & & & & & & & & & \\
\hline $12 X-6,50-51$ & 147.30 & $G$ & & $\mathrm{C}$ & $\mathrm{C}$ & $c$ & $\mathrm{~A}$ & & $\mathrm{C}$ & $c$ & & $\mathrm{C}$ & $\mathrm{R}$ & & & & & & & & & & \\
\hline $12 \mathrm{X}-6,104-106$ & 147.84 & $\mathrm{G}$ & & A & $\mathrm{F}$ & & & & & & & $\mathrm{C}$ & & & & & & & & & & & \\
\hline $12 X-6,110-111$ & 147.90 & $G$ & & C & C & $\mathrm{C}$ & $\mathrm{A}$ & & $\mathrm{F}$ & $\mathrm{C}$ & & $\mathrm{c}$ & & & & & & & & & & & \\
\hline $12 \mathrm{X}-\mathrm{CC}, 10-12$ & 148.20 & $G$ & & $\mathrm{C}$ & $\mathrm{C}$ & $\mathrm{F}$ & $\mathrm{A}$ & & $\mathrm{F}$ & $\mathrm{C}$ & & $\mathrm{C}$ & & & & & & & & & & & \\
\hline $12 \mathrm{X}-\mathrm{CC}, 18-19$ & 148.28 & $G$ & & A & $\mathrm{F}$ & $\mathrm{R}$ & & & & & & $\mathrm{C}$ & & & & & & & & & & & \\
\hline $13 \mathrm{X}-1,17-19$ & 149.87 & $G$ & & & A & $\mathrm{R}$ & & & & & & & & & & & & & & & & \multirow{6}{*}{ 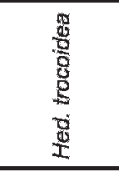 } & \\
\hline $13 \mathrm{X}-1,60-62$ & 149.50 & $G$ & & $\mathrm{R}$ & C & $\mathrm{F}$ & $\mathrm{A}$ & & $F$ & $\mathrm{C}$ & & & & & & & & & & & & & \\
\hline $13 \mathrm{X}-2,17-19$ & 150.57 & $G$ & & & A & $\mathrm{R}$ & & C & & & & & & & & & & & & & & & \\
\hline $13 \mathrm{X}-2,60-62$ & 151.00 & $G$ & & $\mathrm{R}$ & $\mathrm{C}$ & $\mathrm{C}$ & $\mathrm{A}$ & $\mathrm{R}$ & $\mathrm{C}$ & $F$ & & & & & & & & & & & & & \\
\hline $13 X-3,17-19$ & 152.87 & $G$ & & & $F$ & $\mathrm{~F}$ & & $\mathrm{R}$ & & & & & & & & & & & & & & & \\
\hline $13 \times-3,60-62$ & 152.50 & $\mathrm{G}$ & & $\mathrm{R}$ & c & $F$ & $F$ & $\mathrm{R}$ & $\mathrm{F}$ & $F$ & & & & & & & & & & & & & \\
\hline $13 X-C C, 25-27$ & 153.05 & $\bar{M}$ & $F$ & & $F$ & $\mathrm{~F}$ & A & & $F$ & $F$ & & & & & & & & & & & & \multirow{2}{*}{$G$ alger. } & \\
\hline $13 \mathrm{X}-\mathrm{CC}, 48-49$ & 153.28 & $M$ & $F$ & $F$ & $F$ & $F$ & $\mathrm{R}$ & & & & & & & & & & & & & & & & \\
\hline
\end{tabular}

Western Europe (Birkelund and others, 1984), tend to have highly provincial distributions and often cannot be correlated globally (Hancock, 1991). Although planktic microfossils are more useful for global correlation, their stratigraphic distributions have generally not been well integrated with ammonite zonal schemes (Owen, 2002).

Studies of potential Aptian/Albian GSSPs in the Vocontian Basin (southeast France) have provided an improved integrated framework for correlation of a number of macro- and microfossil biostratigraphic datums relative to various chemostratigraphic data (Kennedy and others, 2000; Herrle and Mutterlose, 2003; Herrle and others, 2004; Friedrich and others, 2005). The most widely recognized microfossil events associated with the AABI are the LO of the calcareous nannofossil Praediscosphaera columnata s. str. and the $\mathrm{HO}$ of the planktic foraminifer Paraticinella eubejaouaensis (= Ticinella bejaouaensis of previous studies). The former datum is used to identify the base of Zones NC8 and CC8 for the zonal schemes of Sissingh (1977) and Roth (1978), respectively. According to Bown (in Kennedy and others, 2000) this species is represented by an evolutionary series from an older elliptical form that first appears in the late Aptian ( $P r$. columnata s.1.) and a younger circular form that first appears in the early Albian (Pr. columnata s.s.).

In the Vocontian Basin, three distinct black shales occur across the AABI. These include the Niveau Jacob and the overlying Niveau Kilian, which Kennedy and others (2000) 
TABLE 2. Relative abundance estimates for planktic foraminiferal from upper Aptian through upper Albian from DSDP Site 511. See Table 1 for explanation of abbreviations.

\begin{tabular}{|c|c|c|c|c|c|c|c|c|c|c|c|c|c|c|c|c|c|c|c|c|c|c|c|c|c|c|c|}
\hline $\begin{array}{c}\text { DSDP } \\
\text { Site } 511\end{array}$ & 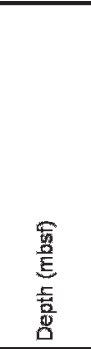 & & 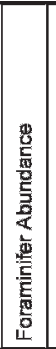 & 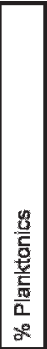 & 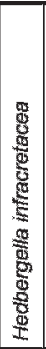 & 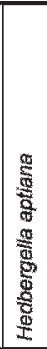 & 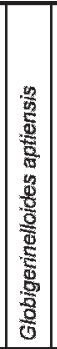 & 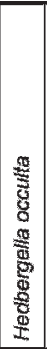 & 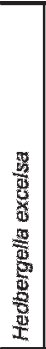 & 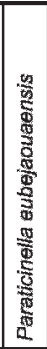 & 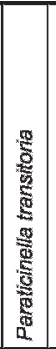 & 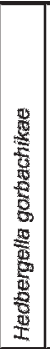 & 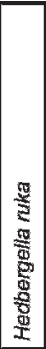 & 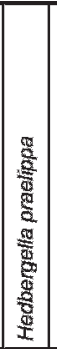 & 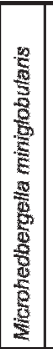 & 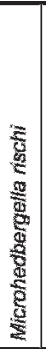 & 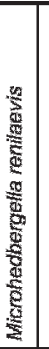 & 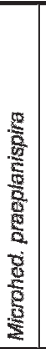 & 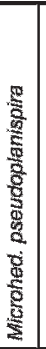 & & 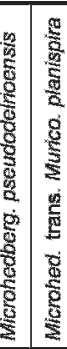 & 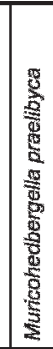 & 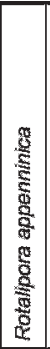 & 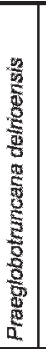 & 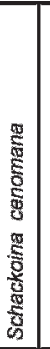 & 产 & : \\
\hline $49-5,66-68$ & 429.65 & $E$ & A & & & & & & - & - & & & & & & ב & & & & $\bar{n}$ & 5 & & & & & ppe- & \\
\hline $49-6,24-26$ & 430.44 & & A & 99 & & & & & & & & & & & & & & 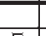 & & $\mathbf{R}$ & $\mathrm{C}$ & & & & - & & \\
\hline $50-1,17-19$ & 432.66 & $G$ & A & $\frac{99}{98}$ & & & & & & & & & & & & & & $F$ & & $\mathbf{R}$ & $\mathrm{c}$ & & & & & & \\
\hline$\frac{50-1,29-33}{50-229-33}$ & $\begin{array}{r}432.78 \\
434.28\end{array}$ & $\frac{G}{E}$ & $\frac{A}{A}$ & $\frac{98}{98}$ & & & & & & & & & & & & & & A & - & $\frac{R}{R}$ & \begin{tabular}{l|l}
$A$ & $C$ \\
$A$ & $F$
\end{tabular} & & & & & & \\
\hline $50-3,26-28$ & 435.73 & $\mathrm{E}$ & A & 97 & & & & 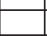 & 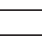 & & & & 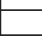 & & & 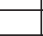 & & $\mathrm{c}$ & $\mathrm{R}$ & $\frac{n}{R}$ & \begin{tabular}{|l} 
\\
\end{tabular} & & 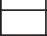 & & & & \\
\hline $50-4,27-29$ & 435.79 & $E$ & A & 97 & & & & & & & & & & & & & & A & $F$ & R & & & & & & "gig & \\
\hline 50-CC & 437.61 & $E$ & A & 98 & & & & & & & & & & & & & & A & & & & & & & & & \\
\hline $51-1,22-24$ & $\begin{array}{l}442.22 \\
43772\end{array}$ & \begin{tabular}{|l}
$E$ \\
$E$
\end{tabular} & $\begin{array}{l}A \\
A\end{array}$ & 98 & & & & & & & & & & & & 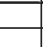 & & A & $F$ & R & \begin{tabular}{c|l}
$\mathrm{C}$ & \\
$\mathrm{F}$
\end{tabular} & & & & & & \\
\hline $51-3,21-23$ & $440.1<1$ & $\frac{\mathrm{c}}{\mathrm{E}}$ & $\frac{A}{A}$ & 80 & & & & & & & & & & & & - & & $\frac{A}{A}$ & $\frac{R}{R}$ & & & & & & & & \\
\hline $51-4,18-21$ & 446.68 & $E$ & C & 95 & & & & & & & & & & & & - & & A & $\mathrm{R}$ & R & $F$ & & & & & & \\
\hline $51-5,24-26$ & 448.24 & $\mathrm{E}$ & A & 94 & & & & & & & & & & & & & & A & $\mathrm{R}$ & $F$ & $\mathrm{R}$ & & & & & & \\
\hline $51-6,24-26$ & 449.74 & \begin{tabular}{|l} 
E \\
\end{tabular} & A & 95 & & & & & & & & & & & & E & & A & $\mathrm{R}$ & $\mathrm{R}$ & $F$ & & & & & & \\
\hline$\frac{51-C C}{52-1,20-22}$ & $\frac{450.98}{451.70}$ & \begin{tabular}{|l|l}
$E$ \\
$E$
\end{tabular} & \begin{tabular}{|l|}
$A$ \\
$A$
\end{tabular} & & & & & 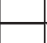 & & & & & & & & - & & $\frac{A}{A}$ & $\mathrm{~F}$ & $\frac{R}{R}$ & $\frac{F}{F}$ & & 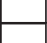 & & & & \\
\hline$\frac{12-1,1, v 225}{52-2,23-25}$ & $\frac{451.10}{453.23}$ & \begin{tabular}{|l}
$E$ \\
$E$ \\
\end{tabular} & \begin{tabular}{|l|} 
\\
$A$
\end{tabular} & 95 & & & & & & & & & & & & $\mathrm{R}$ & & $\frac{A}{A}$ & r & $\frac{R}{R}$ & $\frac{\mathrm{F}}{\mathrm{C}}$ & & & & & & \\
\hline $52-3,25-27$ & 454.75 & \begin{tabular}{|l}
$E$ \\
5
\end{tabular} & c & 96 & & & & & & & & & & & & c & & $A_{1}$ & $F$ & R & F & & & & & & \\
\hline $52-4,70-72$ & $\begin{array}{l}457.91 \\
57.77\end{array}$ & $E$ & $\begin{array}{ll}c \\
\end{array}$ & & & & & & & & & & & & & $\mathrm{C}$ & & A & $F$ & & $\bar{R}$ & & & & 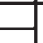 & & \\
\hline$\frac{52-3,27-29}{52-6,27-29}$ & $\frac{451, X t}{458.98}$ & $E$ & $\frac{R}{F}$ & & & & & & & & & & & & & $\frac{F}{F}$ & & $A$ & $\mathrm{c}$ & & & & & & & & \\
\hline $52-7,8-10$ & 460.29 & $E$ & A & 99 & & & & & & & & & & & & $R$ & $\mathrm{R}$ & A & $\mathrm{F}$ & & $\mathrm{R}$ & & & & & & \\
\hline $53-1,25-27$ & 461.25 & $\mathrm{E}$ & $\mathrm{C}$ & 75 & & & & & & & & & & & & $\mathrm{R}$ & $\mathrm{F}$ & A & $\mathrm{F}$ & & & & & & & & \\
\hline $53-2,23-25$ & 462.73 & $E$ & $F$ & 74 & & & & & & & & & & & & $\mathrm{~F}$ & & A & $F$ & & & & & & & & \\
\hline $53-4,27-29$ & $\begin{array}{l}464.27 \\
465.73\end{array}$ & E & A & $\frac{67}{58}$ & & & & & & & & & & & & - & $\mathrm{c}$ & A & $F$ & & & & & & & & $\frac{.9}{30}$ \\
\hline $53-6,25-27$ & 468.75 & E & A & 86 & & & & & & & & & & & & $\mathrm{~F}$ & $\mathrm{c}$ & $\mathrm{A}$ & $\frac{K}{F}$ & & & & & & & & \\
\hline $53-\mathrm{CC}, 0-2$ & 470.00 & $E$ & A & 89 & & & & & & & 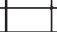 & & & & & $F$ & c & $\mathrm{A}$ & $F$ & & & & & & & 急 & \\
\hline $54-1,22-24$ & 470.72 & $E$ & A & 84 & & & & & & & & & & & & F & $\mathrm{F}$ & A & $\mathrm{R}$ & & & & & & & $\frac{9}{3}$ & \\
\hline $54-2,20-22$ & 471.74 & & A & & & & & & & & & & & & & & & A & $F$ & & & & & & & & \\
\hline $54-3,22-24$ & 473.72 & $E$ & A & 26 & & & & & & & & & & & & 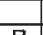 & $\mathrm{c}$ & A & & & & & & & 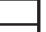 & & \\
\hline$\frac{54-4,22-24}{54-5,22-24}$ & $\begin{array}{l}475.22 \\
476.72\end{array}$ & $\frac{E}{F}$ & c & & & & & & & & & & & & & $\mathbf{R}$ & & A & $\mathrm{R}$ & & & & & & - & & \\
\hline $54-6,22-24$ & 478.22 & $\frac{E}{E}$ & \begin{tabular}{|l|} 
\\
$A$
\end{tabular} & \begin{tabular}{|l|}
38 \\
18
\end{tabular} & & & & & & & 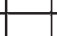 & & & & 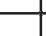 & $R$ & $\frac{C}{A}$ & $\frac{A}{F}$ & R & & & & & & - & & \\
\hline $55-1,24-26$ & 480.24 & $\bar{E}$ & A & 17 & & & & & & & & & & & & $\mathrm{R}$ & A & $\mathrm{C}$ & $\mathrm{R}$ & & & & & & & & \\
\hline $55-1,130-131$ & 481.30 & $\mathrm{E}$ & A & 4 & & & & & & & & & & & $\mathbf{R}$ & $\mathrm{R}$ & A & 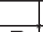 & & & & & & & & & \\
\hline$\frac{55-1,146-147}{55-3}$ & $\begin{array}{ll}481.46 \\
192.50\end{array}$ & $E$ & A & $\frac{8}{14}$ & & & & & & & 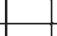 & & & & $\mathrm{F}$ & & A & $\mathrm{R}$ & & & & & & & & & \\
\hline$\frac{55-2,100-101}{55-3,24-26}$ & $\frac{482.50}{483.24}$ & $\frac{E}{E}$ & $\frac{A}{A}$ & $\frac{11}{13}$ & & & & & & & & & & & $\frac{F}{R}$ & $\mathrm{R}$ & $\frac{A}{A}$ & R & & & & & & & - & & \\
\hline $55-3,100-101$ & 484.01 & $E$ & A & 18 & & & & & & & 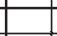 & & & & $\mathrm{A}$ & & A & & & & & & & & & & \\
\hline $55-4,20-21$ & 484.71 & $\frac{G}{E}$ & A & \begin{tabular}{|l|l|}
30 \\
1
\end{tabular} & 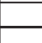 & & & & & & & & & & A & 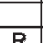 & $\frac{c}{c}$ & & & & & & & & Z & & \\
\hline$\frac{53-4,4-4-6}{55-4,41-42}$ & $\begin{array}{l}\frac{404.55}{484.91} \\
\end{array}$ & $\frac{c}{G}$ & C & $\frac{1}{8}$ & & & & & & & & & & & $\frac{A}{A}$ & & & & & & & & & & & & \\
\hline & 485.11 & $\mathrm{G}$ & 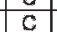 & 5 & & & & & & & & & & & $n$ & & R & & & & & & & & 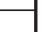 & 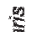 & \\
\hline $55-4,96-97$ & 485.46 & $\mathrm{G}$ & $\mathrm{R}$ & 2 & & & & & & & & & & 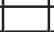 & 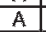 & & & & & & & & & & 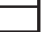 & $\frac{\mathrm{s}}{\mathrm{s}}$ & \\
\hline $24-26$ & 485.95 & $\mathrm{G}$ & $\mathrm{R}$ & 0 & & & & & & & & & & $F$ & 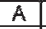 & & & & & & & & & & 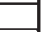 & 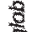 & \\
\hline$\frac{55-5,27-29}{55,23295}$ & 485.98 & $M$ & $\mathrm{~F}$ & 0 & & & & & & & & & & $\mathrm{R}$ & & & & & & & & & & & & & \\
\hline & 486.04 & 5 & $\mathrm{~F}$ & 0 & & & & & & & & & & $\mathrm{~F}$ & $\frac{A}{A}$ & & & & & & & & & & - & $\approx$ & \\
\hline$\frac{11-42}{11-42}$ & 486.12 & $\bar{E}$ & $\bar{F}$ & 4 & & & & & & & & & & $\bar{A}$ & $\bar{A}$ & & & & & & & & & & & & \\
\hline $43-44$ & 486.14 & $\bar{E}$ & $F$ & 0 & $\bar{R}$ & & & & & $\bar{F}$ & & & & $\bar{A}$ & $\overline{\mathrm{A}}$ & & & & & & & & & & & & \\
\hline & 486. & & A & D & & & & & & $\mathrm{R}$ & & & & A & $\underline{C}$ & & & & & & & & & & & & \\
\hline & 486.31 & 듬 & A & 0 & - & & & & - & $\mathrm{R}$ & $R$ & & & $c$ & A & & & & & & & & & & - & & \\
\hline & 486.5 & G & $\frac{L}{1}$ & 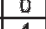 & & & & & & & R & & & A & A & & & & & & & & & & - & & \\
\hline & $\frac{486.7}{4897}$ & $\sigma_{0}$ & $\frac{6}{n}$ & 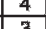 & & & & & & $E_{0}$ & & & & A & A & & & & & & & & & & - & & \\
\hline$\frac{50-3,100-}{55-5,110-}$ & $\begin{array}{r}406.61 \\
4861\end{array}$ & $\underline{G}$ & $C_{A}$ & $\frac{3}{1}$ & & $R_{R}$ & & & A & $\pi$ & R & & & $A$ & & & & & & & & & & & & & \\
\hline 5 & 4469 & G & A & & $\bar{R}$ & $\frac{k}{R}$ & & & A & $\mathrm{R}$ & R & & & $\bar{A}$ & & & & & & & & & & & - & & \\
\hline $55-5,131-133$ & 487.02 & $\mathrm{G}$ & A & 0 & & & & & A & R & $\mathrm{R}$ & & $\mathrm{F}$ & A & & & & & & & & & & & 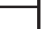 & & \\
\hline & & & $\bar{C}$ & & $R$ & & & & c & $\mathrm{R}$ & & & & A & & & & & & & & & & & & & 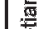 \\
\hline & 487 & & & & & & & & A & $\mathrm{R}$ & & & & $\mathrm{c}$ & & & & & & & & & & & & & \\
\hline & 487.77 & $M_{M}$ & $\mathrm{c}$ & & $R_{R}$ & & & & A & & & & & & & & & & & & & & & & & & \\
\hline & & $A-$ & A & & F & & & & A & - & & & & & & & & & & & & & & & & 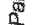 & \\
\hline & 489.72 & $\mathrm{M}$ & A & 1 & & & & & A & $F$ & & $R_{R}$ & R & & & & & & & & & & & & & & \\
\hline & 491.23 & $\mathrm{G}$ & A & 17 & A & & & & A & $R$ & $\mathrm{R}$ & $R$ & R & & & & & & & & & & & & & & \\
\hline & 492.75 & 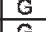 & A & $\frac{8}{41}$ & A & $\mathrm{R}$ & & & A & & & & & & & & & & & & & & & & & \% & \\
\hline $56-$ & $\begin{array}{l}494.11 \\
495.51\end{array}$ & $\mathrm{E}$ & $\frac{R}{A}$ & $\frac{11}{92}$ & $\mathrm{~A}$ & & & & $\frac{A}{A}$ & & & & $F$ & & & & & & & & & & & & & 悹 & \\
\hline $5,22-24$ & 495.72 & $E$ & A & 13 & $\bar{A}$ & & & & c & & & & & & & & & & & & & & & & & 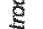 & \\
\hline$\frac{57-4,38-52}{58, C C}$ & $\frac{503.88}{514.70}$ & $\frac{P}{P}$ & $\frac{A}{R}$ & & A & & & $\mathrm{F}$ & & & & & 4 & 4 & +1 & & & & + & & & & & & & 모 & \\
\hline
\end{tabular}


TABLE 3. Relative abundance estimates for planktic foraminiferal from upper Aptian through upper Albian from DSDP Site 545. See Table 1 for explanation of abbreviations.

\begin{tabular}{|c|c|c|c|c|c|c|c|c|c|c|c|c|c|c|c|c|c|c|c|c|}
\hline $\begin{array}{c}\text { DSDP Site } \\
545\end{array}$ & 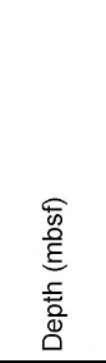 & 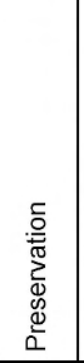 & 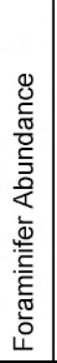 & 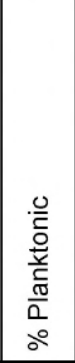 & 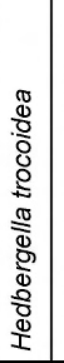 & 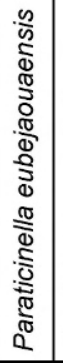 & 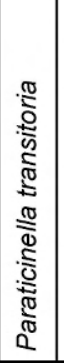 & 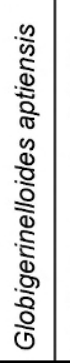 & 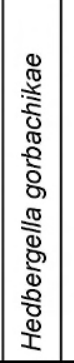 & 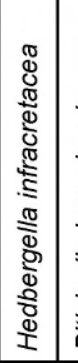 & 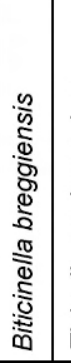 & 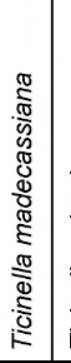 & 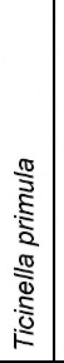 & 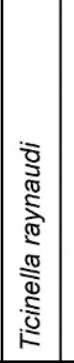 & 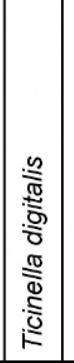 & 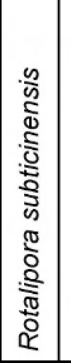 & 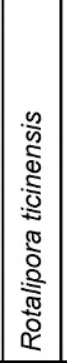 & 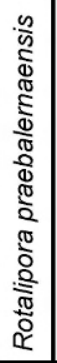 & 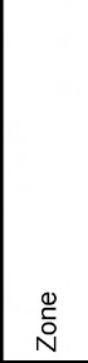 & ه্ৰ \\
\hline 40R-1, 41-43 & 369.91 & $M$ & A & 94 & & & & & & & $x$ & $x$ & $x$ & $x$ & $\mathrm{x}$ & $x$ & $x$ & $x$ & \multirow{3}{*}{ 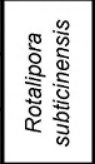 } & \multirow{3}{*}{ 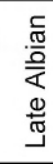 } \\
\hline $40 R-3,41-43$ & 372.91 & M & A & 90 & & & & & & & $x$ & $x$ & $x$ & $x$ & $x$ & $x$ & $x$ & $x$ & & \\
\hline 40R-5, 8-10 & 375.28 & $\mathrm{M}$ & A & 96 & & & & & & & $x$ & $x$ & $x$ & $x$ & $\mathrm{x}$ & $x$ & $x$ & $x$ & & \\
\hline 40R-6, 41-43 & 377.11 & $M-G$ & C & 0.3 & & & & $\mathrm{x}$ & $\mathrm{x}$ & $x$ & & & & & & & & & \multirow{11}{*}{ 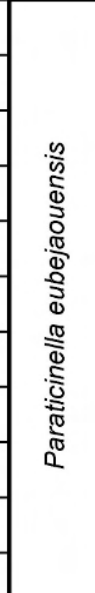 } & \multirow{11}{*}{ 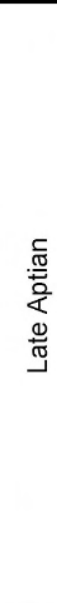 } \\
\hline 40R-6, 60-62 & 377.30 & $M-G$ & C & 0.4 & & $\mathrm{x}$ & & $x$ & $x$ & $x$ & & & & & & & & & & \\
\hline $41 \mathrm{R}-1,46-48$ & 379.46 & $\mathrm{M}$ & $\mathrm{F}$ & 0.2 & & & & & & $x$ & & & & & & & & & & \\
\hline 41R-3, 72-75 & 382.72 & $M-G$ & $\mathrm{C}$ & 0 & & & & & & $x$ & & & & & & & & & & \\
\hline 41R-4, 27-30 & 383.77 & $M-G$ & $C$ & 0.1 & & $\mathrm{x}$ & $x$ & & & $x$ & & & & & & & & & & \\
\hline 42R-1, 94-96 & 389.44 & G & $\mathrm{C}$ & B & & & & & & & & & & & & & & & & \\
\hline $42 \mathrm{R}-3,52-55$ & 392.02 & G & C & B & & & & & & & & & & & & & & & & \\
\hline $42 \mathrm{R}-5,17-20$ & 394.67 & $M-G$ & $\mathrm{~F}$ & 0 & & & & & & $x$ & & & & & & & & & & \\
\hline 43R-1, 64-67 & 398.64 & $M-G$ & $\mathrm{~F}$ & 0 & & $\mathrm{x}$ & $\mathrm{x}$ & & & $\mathrm{x}$ & & & & & & & & & & \\
\hline 43R-3, 48-50 & 401.48 & M-G & $\mathrm{F}$ & 2 & & $\mathrm{x}$ & & $x$ & $\mathrm{x}$ & $x$ & & & & & & & & & & \\
\hline $43 R-5,32-35$ & 404.00 & $M-G$ & $\mathrm{~F}$ & 5 & $\mathrm{x}$ & & & $\mathrm{x}$ & $\mathrm{x}$ & $\mathrm{x}$ & & & & & & & & & & \\
\hline
\end{tabular}

placed in the upper Aptian, and the Niveau Paquier, which they placed at the base of the Albian.

The planktic foraminifer Pa. eubejaouaensis has been traditionally used as a proxy for identifying the Aptian/ Albian boundary by numerous foraminiferal researchers (e.g., Sigal, 1977; Sliter, 1989; Premoli Silva and Sliter, 1999; Bellier and others, 2000; Bellier and Moullade, 2002), and its stratigraphic utility has been demonstrated by its distinctive appearance and global distribution in a wide range of marine settings. Stratophenetic observations of $P a$. eubejaouaensis have revealed a series of evolutionary changes represented by an increase in chamber number, flattening of spire height, widening of the umbilicus, and increased development of ridge ornamentation that parallels the shell periphery (Premoli Silva and others, 2009).

In the absence of a formal definition of the base of the Albian Stage several authors (e.g., Moullade, 1966; Sigal, 1977; Hart and others, 1996) have used the LO of the distinctive benthic foraminifer Pleurostomella subnodosa Reuss to identify the Aptian/Albian boundary. Unfortunately, the range of this species has not been calibrated relative to the extinction of Paraticinella eubejaouaensis, and Pl. subnodosa was not identified in Holbourn and Kuhnt's (2001) biostratigraphic study of benthic foraminifer distributions at Site 1049.

\section{GEOLOGIC SETTING AND PREVIOUS AGE ASSIGNMENTS OF DEEP-SEA SECTIONS}

\section{DSDP Sites 390, 392; ODP Site 1049 (Blake Plateau)}

The Blake Nose is a gently sloping ramp on Blake Plateau that deepens eastward from $\sim 1000-2700 \mathrm{~m}$ water depth. It is covered by an eastward thinning drape of Paleogene and Cretaceous strata that have never been buried by younger deposits (Norris and others, 1998). Upper Aptian-middle Albian sediments were cored on the eastern margin of Blake Nose at DSDP Sites 390 and 392, and at ODP Site $1049 \sim 450 \mathrm{~km}$ east of Jacksonville, Florida (Fig. 2). The shallow burial depth and predominance of intervals with high clay content account for extraordinarily good microfossil preservation at these sites. Core depths, core recovery, and correlation of these sites are presented in Figure 3.

\section{DSDP Site 390 AND ODP Site 1049}

Sites 390 and 1049 are located in the subtropical western North Atlantic $\left(30^{\circ} 8.53^{\prime} \mathrm{N}, 76^{\circ} 6.72^{\prime} \mathrm{W}\right)$ at a water depth of $2670 \mathrm{~m}$. Benthic foraminiferal assemblages indicate that the late Aptian-early Albian interval accumulated at middlebathyal depths ( $\sim 800-1500 \mathrm{~m})$ according to Norris and others 
TABLE 4. Relative abundance estimates for planktic foraminiferal from upper Aptian through upper Albian from ODP Hole 763B. See Table 1 for explanation of abbreviations.

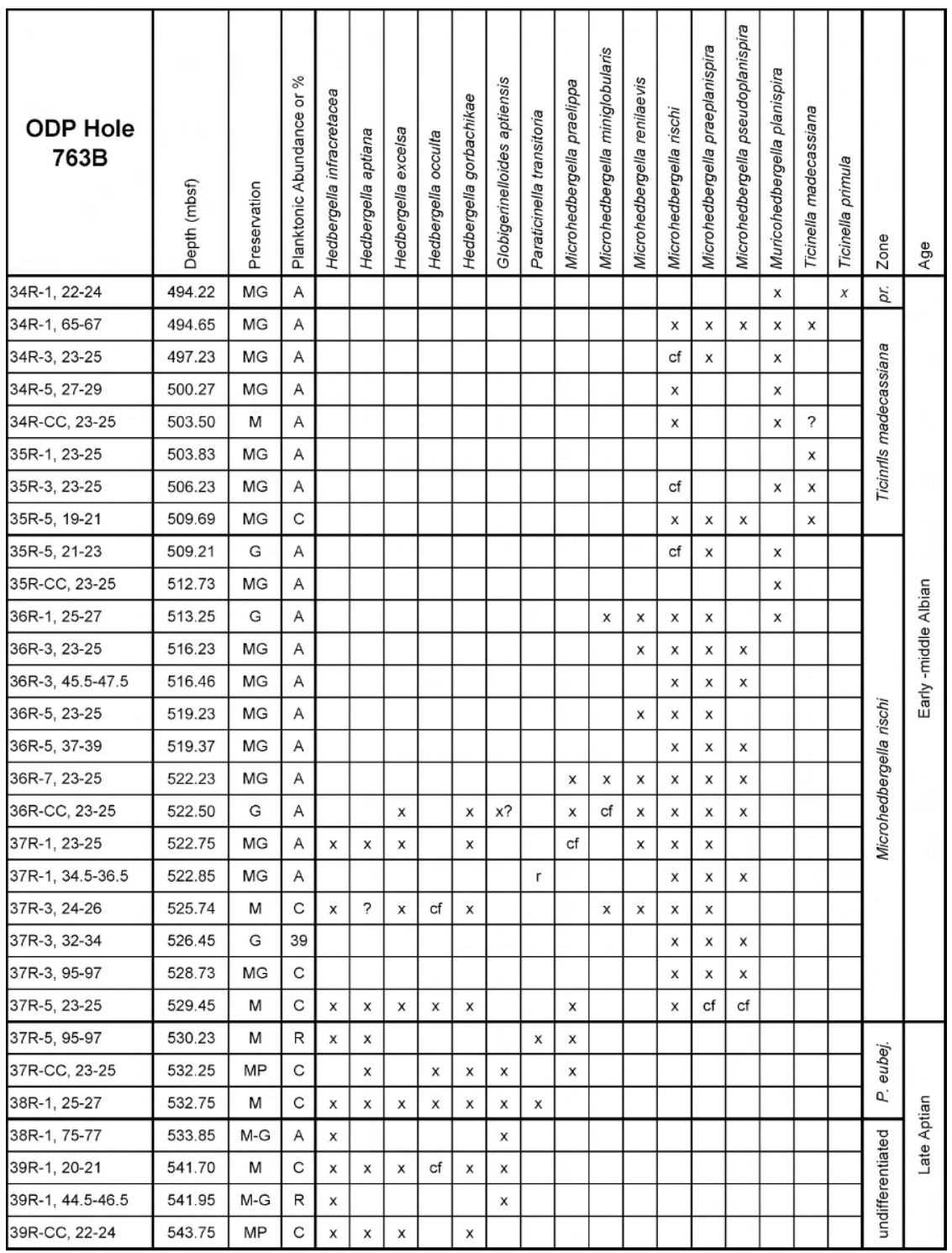

(1998), or deepened from outer shelf to upper slope depths during the Aptian to middle slope depth during the Albian according to Holbourn and Kuhnt (2001). The paleomagnetic study of Ogg and Bardot (2001) places these sites at $\sim 25^{\circ} \mathrm{N}$ paleolatitude from mid-Cretaceous through Eocene.

Although Site 1049 was meant to be a reoccupation of DSDP Site 390 (and Hole 390A), differences in Campanian-Maastrichtian stratigraphic unit thicknesses between the two sites suggest that their locations may be offset by a significant distance, or that there was significant relief on the ancient seafloor (Huber and others, 2008). AABI sediments at both sites are characterized by a $\sim 32$-m-thick sequence of rhythmically alternating reddish and green bioturbated calcareous clay and clay-rich chalk (Benson and others, 1978; Norris and others, 1998). A 37-cm-thick laminated black shale, which has a total organic carbon content ranging $2-11.5 \%$, was recovered from the lower Albian at each of the Site 1049 drill holes (e.g., 142.75-
143.12 mbsf at Hole 1049C). This interval has been identified as the regional expression of OAE $1 \mathrm{~b}$ and was correlated with the Niveau Paquier in the Vocontian Basin (Barker and others, 2001; Erbacher and others, 2001).

The Aptian/Albian boundary at Site 1049 was placed by Bellier and others (2000) at the HO of Paraticinella eubejaouensis within Sample 20-5, 68-73 cm in Hole 1049A (152.87 mbsf), 12X-1, 17-19 cm in Hole 1049B (160.18 mbsf), and 12X-6, 16-18 cm (147.47 mbsf) in Hole 1049C. This boundary was judged by Bellier and others (2000) to be biostratigraphically complete in all three drill holes at Site 1049, yet the depths of the boundary in the three holes vary significantly.

At Site 390, Gradstein (1978) correlated Cores 390-3 and -4 with the middle Albian Ticinella primula Zone and assigned Core 390-5 to the upper Aptian Globigerinelloides algerianus Zone, placing the Aptian/Albian boundary within a coring gap between cores 390-4 and -5 . 


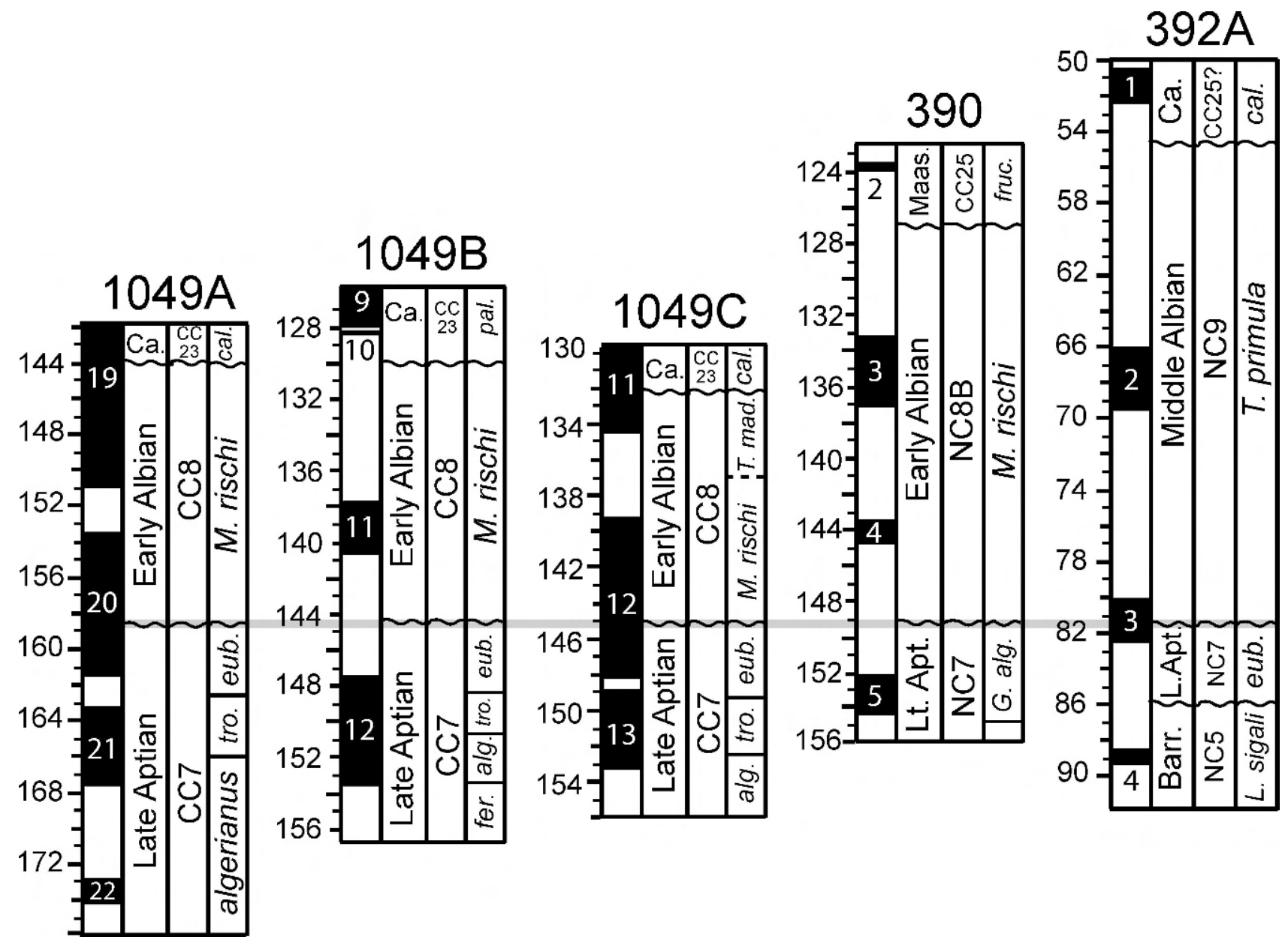

Figure 3. Correlation of DSDP Sites 390 and 392A and ODP Holes 1049A, B, and C on Blake Plateau. The sections shows, from left to right, core depth (meters below seafloor) core number, core recovery (black), calcareous nannofossil biozones, and planktic foraminiferal biozones. Wavy horizontal lines represent position of unconformities. Calcareous nannofossil biozonation (CC zones) from Browning and Watkins (2008) for Site 1049 and Bralower et al. (1997) for Sites 390 and 392A. Ca $=$ Campanian. Planktic foraminiferal biozone abbreviatons: fer. = Globigerinelloides ferreolensis; alg. $=$ Globigerinelloides algerianus; tro. $=$ Hedbergella trocoidea $;$ eub. $=$ Paraticinella eubejaouaensis; cal. $=$ Radotruncana calcarata; pal $=$ Pseudoguembelina palpebra $L .=$ Leupoldina, $M=$ Microhedbergella, $T=$ Ticinella .

\section{DSDP SITE 392A}

Site 392A is located about $26 \mathrm{~km}$ south of Site 390/1049 at $2607 \mathrm{~m}$ water depth. Aptian-Albian sediments consisting of nannofossil ooze and clay were drilled between 66.0 and $88.5 \mathrm{mbsf}$ in the second and third cores at this site (Benson and others, 1978). Gradstein (1978) assigned all of Core 392A-2 to the middle-upper Albian Biticinella breggiensis Zone and placed the Aptian/Albian boundary at an unconformity between Sample 392A-3-3, 50-52 cm, which he assigned to the upper Aptian Globigerinelloides algerianus Zone, and Sample 392A-3-1, 46-48 cm, which he assigned to the middle Albian Ti. primula Zone.

\section{DSDP Site 511 (FAlKland Plateau)}

DSDP Site 511 is located on central Falkland Plateau in the southern South Atlantic $\left(51^{\circ} 00.28^{\prime} \mathrm{S}, 47^{\circ} 58.30^{\prime} \mathrm{W}\right)$ at a water depth of $2589 \mathrm{~m}$. During the late Aptian-early Albian this site was located at about $61^{\circ} \mathrm{S}$ in a relatively narrow east-west trending ocean basin that had limited or no connection with the South Atlantic (Hay and others, 1999;
Fig. 2) and the paleowater depth has been estimated to have been between 100-400 m (Basov and Krashenninikov, 1983). Sediments assigned to the AABI range 430 527.5 mbsf and are mostly composed of muddy chalk and calcareous claystone (Krashenninikov and others, 1981). Bralower and others $(1993,1997)$ revised the planktic foraminiferal and calcareous nannofossil biostratigraphy reported in the Krashenninikov and others (1983) volume and tentatively placed the Aptian/Albian boundary at 483 mbsf where they observed the HO of Paraticinella. eubejaouaensis. Strontium isotope measurements published by Bralower and others (1997) for this level are near 0.70730 , which is close to the LOWESS Sr-isotope model established for the AABI by McArthur and others (2001, Look-up Table Version 4: 08/04).

\section{DSDP SITE 545 (MAZAGAN ESCARPMENT)}

DSDP Site 545 is located in the eastern North Atlantic Ocean $\left(33^{\circ} 39.86^{\prime} \mathrm{N}, 9^{\circ} 21.88^{\prime} \mathrm{W}\right)$ about $200 \mathrm{~km}$ off the northwest coast of Morocco at the foot of the Mazagan Escarpment, in a water depth of $3142 \mathrm{~m}$ (Hinz and others, 
1984). The paleolatitude of this site during the late Aptianearly Albian is projected as $20^{\circ} \mathrm{N}$ (Hay and others, 1999) and the paleodepth has been estimated as $\sim 2000 \mathrm{~m}$ (Sikora and Olsson, 1991). The Aptian-Albian sediments consist mostly of nannofossil claystone and extend from 341 to 531 mbsf. Bralower and others $(1993,1997)$ placed the Aptian/Albian boundary at the extinction of $\mathrm{Pa}$. eubejouaensis, which they identified at 390.75 mbsf (Sample 545$42-2,75 \mathrm{~cm})$. An organic-rich black shale found $30 \mathrm{~cm}$ above this level was correlated with the early Albian OAE1b Paquier event based on the Bralower and others age determination (Leckie and others, 2002) and the presence of an $\sim 1.5 \%$ negative $\delta^{13} \mathrm{C}$ excursion (Herrle and others, 2004; Friedrich and others, 2005; Wagner and others, 2008).

\section{ODP Hole 763B (Exmouth Plateau)}

Site 763 is located in the subtropical Indian Ocean on the southwestern flank of Exmouth Plateau $\left(20^{\circ} 35.21^{\prime} \mathrm{S}\right.$, $112^{\circ} 12.51^{\prime} \mathrm{E}$ ) at $1368 \mathrm{~m}$ water depth (Haq and others, 1990). The late Aptian-early Albian paleolatitude of this site is projected as $61^{\circ} \mathrm{S}$ (Hay and others, 1999) and the paleodepth has been estimated as upper bathyal (200-500 m; Haq and others, 1990). Bralower and others (1997) assigned a $44 \mathrm{~m}$ sequence of zeolitic nannofossil claystone to the upper Aptian-lower Albian but their placement of the Aptian/Albian boundary between Cores 763B-36 and -37 ( $\sim 521 \mathrm{mbsf})$ was uncertain because of the absence of the late Aptian biomarker Paraticinella eubejaouaensis. These authors identified the LO of the calcareous nannofossil Praediscosphaera columnata at 528.75 mbsf (763B-37X-5, 25-27 cm), but they did not differentiate the elliptical versus circular forms that have been used by more recent authors to bracket the Aptian/Albian boundary.

\section{Pré-Guittard Section (Vocontian Basin)}

Detailed sedimentologic, macrofaunal, microfossil, and stable-isotopic studies have been published on the Col de Pré-Guittard section in southeast France to determine its suitability for placing the GSSP for the base of the Albian Stage (e.g., Bréhéret and others, 1986; Bralower and others, 1993; Hart and others, 1996; Bréhéret, 1997; Kennedy and others, 2000; Hancock, 2001; Herrle and Mutterlose, 2003; Herrle and others, 2004). The location information, lithologic succession, and biostratigraphy were summarized by Kennedy and others (2000). The exposure comprises $170 \mathrm{~m}$ of monotonous clay with a number of organic rich black shale and marl marker beds, including the Niveau Jacob, Niveau Kilian, and Niveau Paquier black shale sequences across the AABI.

Bown (in Kennedy and others, 2000) identified the LO of elliptical, subcircular, and circular forms of the calcareous nannofossil Praediscosphaera columnata at $3.5 \mathrm{~m}$ above the Niveau Jacob, $1.5 \mathrm{~m}$ below the Niveau Kilian, and $2.5 \mathrm{~m}$ above the Niveau Paquier black shale, respectively. According to the planktic foraminifer biostratigraphy of Caron (in Kennedy and others, 2000), the HO of $\mathrm{Pa}$. eubejaouaensis in the Pré-Guittard section is $11.5 \mathrm{~m}$ below the Niveau Kilian and $10.0 \mathrm{~m}$ below the LO of "nearcircular" forms of Pr. columnata. Kennedy and others
(2000) propose to place the base of the Albian stage at the base of the Niveau Paquier based on the LO of the ammonite Leymeriella tardefurcata. According to this proposed placement of the Aptian/Albian boundary, the $\mathrm{HO}$ of $\mathrm{Pa}$. eubejaouaensis is in the uppermost Aptian.

\section{TAXONOMIC NOTES AND PHYLOGENETIC CLASSIFICATION OF THE APTIAN-ALBIAN HEDBERGELLIDAE AND ROTALIPORIDAE}

A major revision of the taxonomy and phylogeny of latest Aptian through middle Albian hedbergellids is presented below. This revision is warranted for several reasons: 1) published stratigraphic ranges of most AptianAlbian hedbergellids are very inconsistent, suggesting extensive taxonomic confusion; 2) the classification of hedbergellids and ticinellids has been based on typological species concepts that do not emphasize the importance of wall texture and wall structure, which form the primary basis for classification of the Cenozoic planktic foraminifera (Steineck and Fleisher, 1978; Olsson and others, 1999; Pearson and others, 2006); 3) since the advent of deep-sea drilling, the number of sequences bearing well preserved foraminifera has expanded into older Cretaceous strata, providing unprecedented opportunity for reconstructing lineages of descent that are based on stratophenetic observations of changes in shell microstructure and ornamentation; and 4) detailed observations of species distributions across the AABI reveal the presence of new species and that are considered as ancestral to middle and late Albian trochospiral lineages.

In recognition of the importance of wall microstructure in the classification of Cretaceous planktic foraminifera the Mesozoic Planktic Foraminifera Working Group (MPFWG, 2006) determined that the phylogenetic classification of Cretaceous planktic foraminifera should be primarily based on the diameter of shell perforations and secondarily based on shell ornamentation. This Working Group defined three types of shell wall: microperforate (pore diameter $<1.0 \mu \mathrm{m}$; Fig. 4b), finely perforate (pore diameter 1.0-2.5 $\mathrm{m}$; Fig. 4a), and macroperforate (pore diameter $>2.5 \mu \mathrm{m}$; Fig. 4c). This approach has been used in a number of recent taxonomic studies of planispiral, serial, and trochospiral planktic foraminifera (Verga and Premoli Silva, 2003; Georgescu and Huber, 2006, 2007, 2009; Georgescu, 2007a, 2007b, 2008, 2009; Georgescu and Abramovich, 2008; Georgescu and others, 2009). Ornamentation of hedbergellids, as traditionally defined, includes shell walls that are smooth or covered with randomly distributed perforation cones (volcano-like microstructures perforated by one or more pores), fine to medium pustules (bluntly terminated, solid protrusions from the wall), and fine to medium muricae (sharply terminated, solid protrusions from the wall). Although an imperforate peripheral margin is present in the early ontogeny of serially dissected hedbergellids, this disappears later in ontogeny such that shell pores are evenly distributed throughout the adult chambers (e.g., Huber, 1994).

Establishment of the present phylogenetic classification scheme for Aptian-Albian hedbergellids is based on stratophenetic SEM and light microscope observations of 

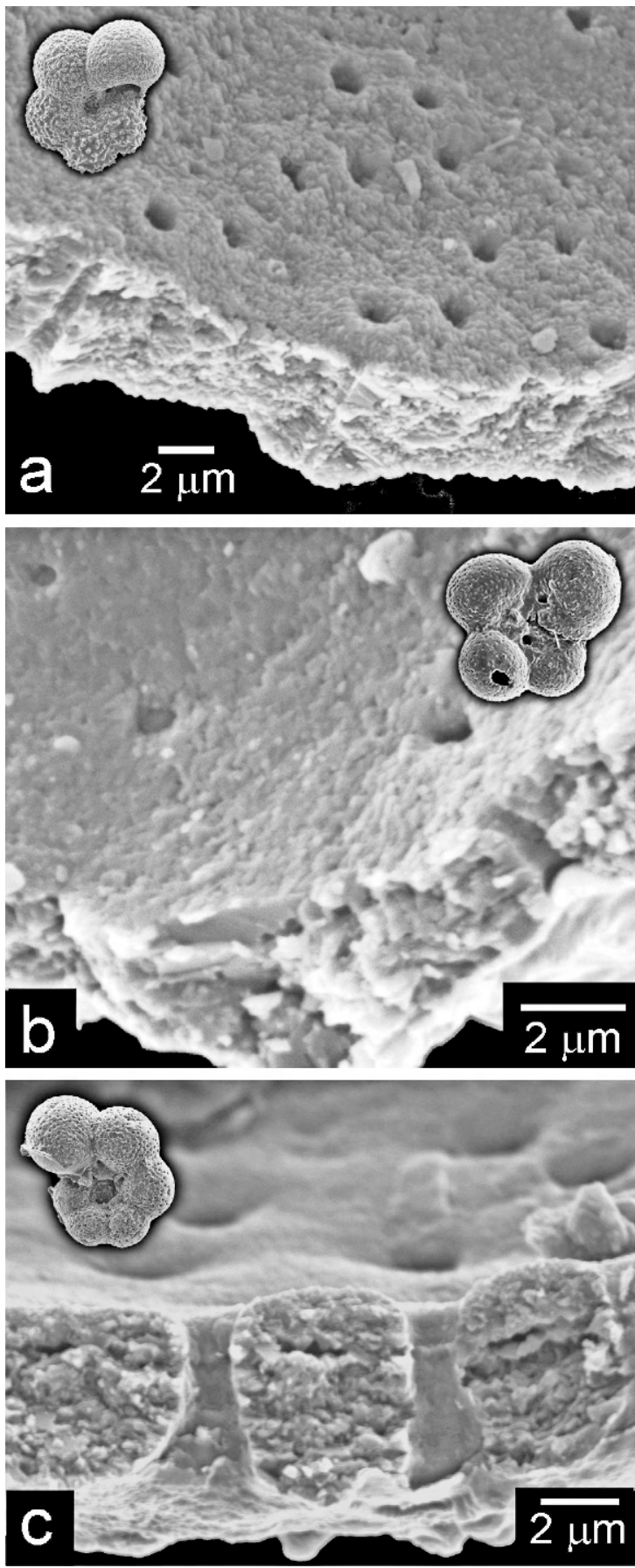

FIgURE 4. Wall microstructure of (a) Hedbergella infracretacea, (b) Microhedbergella renilaevis $\mathrm{n}$. $\mathrm{sp}$., and (c) Muricohedbergella planispira showing differences in pore diameter and wall thickness.

remarkably well preserved species from DSDP Sites 390, 392, 511, 545, and ODP Sites 763 and 1049, as well as correlation of the observed changes with assemblages from the Pré-Guittard section in the Vocontian Basin (Kennedy and others, 2000). Only new and emended genera and species are discussed below; concepts for the remaining species are based on information presented in the Mesozoic Planktonic Foraminiferal Taxonomic Dictionary (see http://portal.chronos.org/gridsphere/gridsphere?cid= res_ foram). The suprageneric classification scheme follows that of Loeblich and Tappan (1987) as modified by Lee (1989), and includes designation of the Paraticinellinae n. subfam.

Supergroup RHIZARIA Cavalier-Smith, 2002 Class FORAMINIFERA d'Orbigny, 1826

Order GLOBIGERININA Delage and Hérouard, 1896 Superfamily ROTALIPORACEA Sigal, 1958

Family HEDBERGELLIDAE Loeblich and Tappan, 1961

Genus Pseudoguembelitria Huber and Leckie, n. gen.

Type species: Pseudoguembelitria blakenosensis Huber and Leckie, n. sp.

Description. Test wall microperforate with pores surrounded by small-sized perforation cones; pustules may be present in the umbilical region. Test small, with early hedbergellid stage and higher trochospire in the adult. Chambers coiled in a variable trochospire with 4.5-5.0 chambers in the initial whorl and 3-4 chambers in the final whorl. Aperture a low interiomarginal, umbilical-extraumbilical arch without periapertural structures.

Remarks. Pseudoguembelitria differs from Hedbergella by having a higher trochospire, more weakly developed perforation cones on the test surface, and fewer chambers in the final whorl. It differs from Guembelitria Cushman, 1933 (late Campanian-early Paleocene) and Archaeoguembelitria Georgescu, 2009 (late Albian-early Turonian) by the early hedbergellid stage and variable trochospire, lower in the early stage and higher in the adult. It differs from Gubkinella (considered by Loeblich and Tapan [1987] to be a benthic foraminifer) in having perforation cones, moreinflated chambers, and a higher-arched aperture, and in lacking a lip.

Etymology. The root of the Greek prefix pseudos, meaning lie or false, is added to the pre-existing genus name Guembelitria.

Species included. Ps. blakenosensis n. sp.

Stratigraphic range. Upper Aptian.

Geographic distribution. Found only at Blake Nose ODP Holes 1049A, 1049B, and 1049C in the subtropical western North Atlantic.

Pseudoguembelitria blakenosensis Huber and Leckie, n. sp. Figs. 5.1, 5.2, 5.4

Description. Test wall microperforate, circular pores 0.3 $0.7 \mu \mathrm{m}$, surface with weakly developed and randomly scattered perforation cones, small pustules may occur in the umbilical region. Test small, globular with early hedbergellid stage, overall diameter/width ratio averaging 1.14; chambers increasing gradually to moderately in size, $11-13$ coiled in a variable trochospire, 4.5-5.0 subglobular chambers in the initial whorl and three to four globular chambers in the final whorl; sutures are depressed, straight to slightly curved; aperture is a low to moderate, semicircular interiomarginal arch at the base of the final chamber, without periapertural structures. Holotype: height $100 \mu \mathrm{m}$, breadth $90 \mu \mathrm{m}$; paratypes: height 100-126 $\mu \mathrm{m}$, width 86-102 $\mu \mathrm{m}$.

Remarks. Pseudoguembelitria blakenosensis is different from other Cretaceous planktic foraminifer species in showing a significant reduction in the number of chambers per whorl as chamber inflation increases. Similarities of the early ontogeny and the perforation cone wall texture 


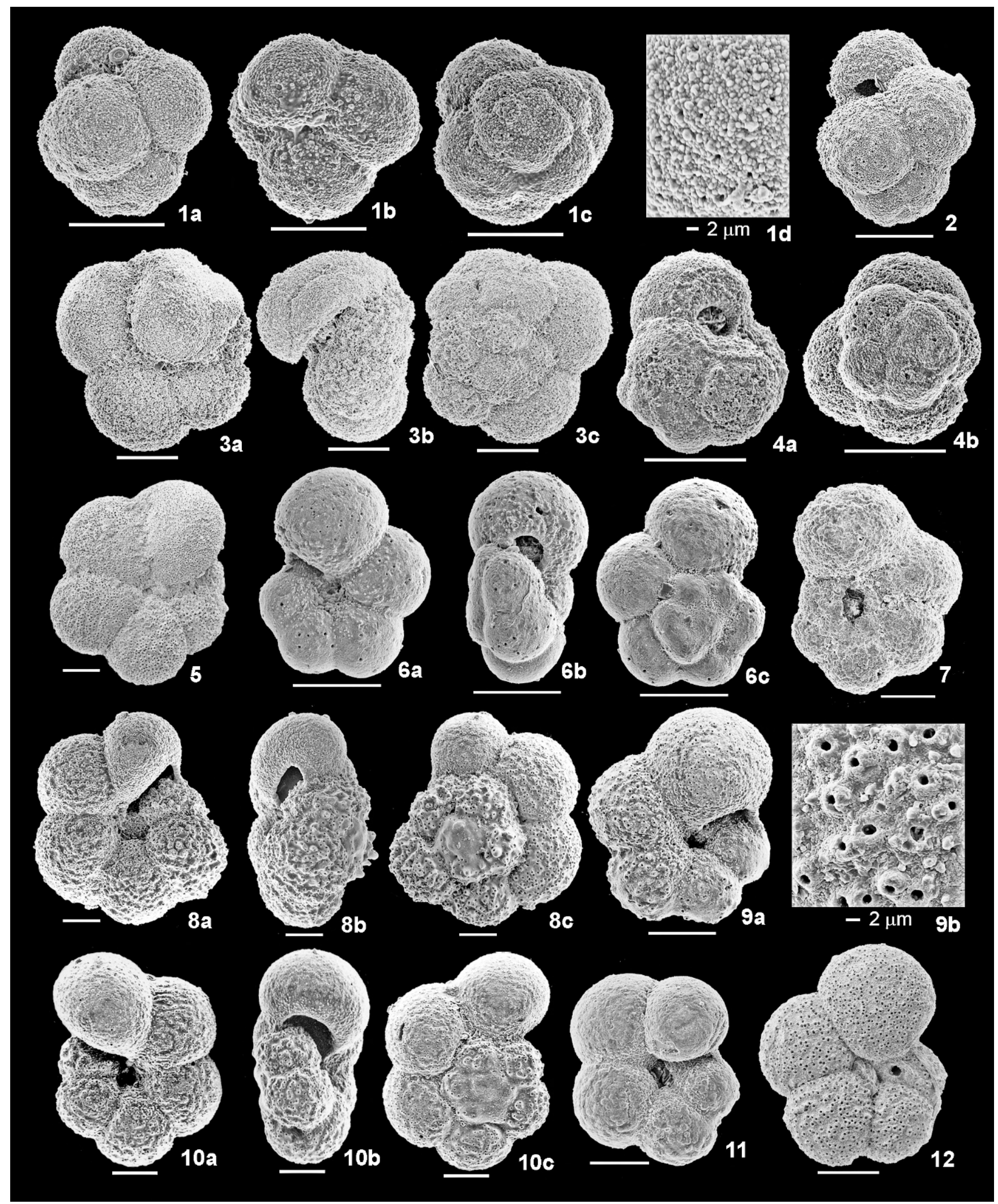

Figure 5. Late Aptian Pseudoguembelitria blakenosensis, Hedbergella gorbachikae, Hd. aptiana, and Hd. infracretacea. Scale bars are $50 \mu \mathrm{m}$ unless shown otherwise. 1, 2, 4 Pseudoguembelitria blakenosensis, n. sp.: 1, holotype USNM 540915, 1049C-12X-5, 0-2 cm, including magnified surface of penultimate chamber showing weakly developed perforation cones; 2, paratype USNM 540916, 1049B-11X-CC; 4, paratype USNM 540917, 1049A-20X-CC. 3, 5 Hedbergella gorbachikae; 3, 1049C-12X-5, 0-2 cm; 5, 511-58-2, 84-86 cm. 6, 7 Hd. aptiana; 6, 511-55-5, 121-123 cm; 7, 763B-37X-5, 95-97 cm. 8-12 Hd. infracretacea: 8, 511-57-4, 38-52 cm; 9, 511-55-5, 131-133 cm, including magnified view of perforation cones on umbilical surface of penultimate chamber; $10,511-56-2,23-25 \mathrm{~cm} ; 11,763 \mathrm{~B}-39 \mathrm{X}-1,44.5-46.5 \mathrm{~cm} ; 12,545-40-6,60-62 \mathrm{~cm}$. 
1049A-20X-4
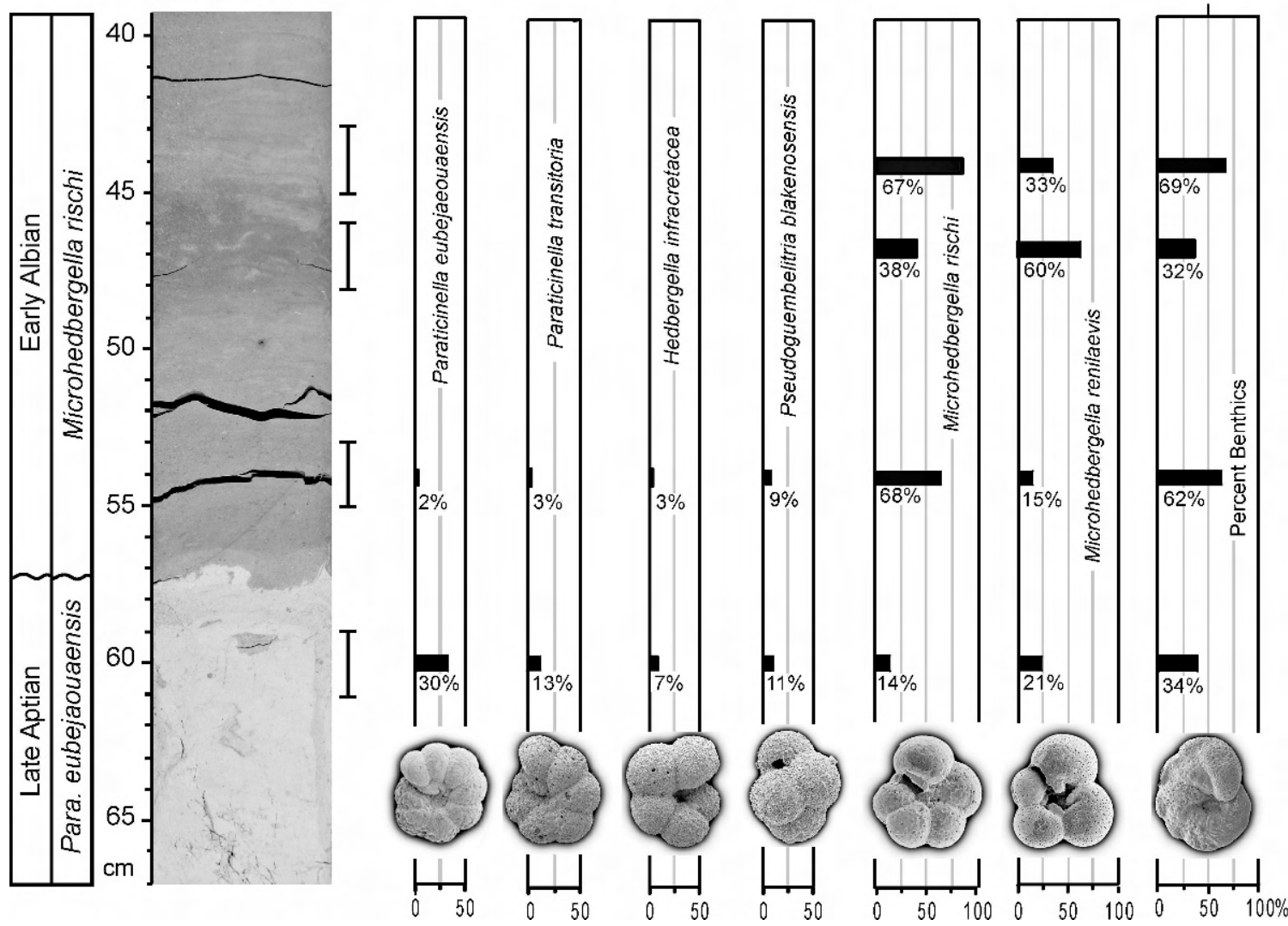

FIGURE 6. Percent relative abundance changes of planktic and benthic foraminifera across a $28 \mathrm{~cm}$ interval spanning the Aptian/Albian boundary at ODP Core-section 1049A-20X-4. Core photo shows lithologic break at the boundary level, which is estimated to represent a hiatus of $\sim 1$ Myr duration (see text for discussion). Note downcore mixing of grayish green Albian sediment in the white Aptian chalk.

(Fig. 5.1d) to Hedbergella infracretacea (Glaessner) indicate that these species may be phylogenetically related. Since both species appear together in the oldest sediments cored at Blake Nose and Ps. blakenosensis has not been identified at any other site, it is not possible to determine when the species evolved and what its ancestor was. At Site 1049 Ps. blakenosensis becomes extinct at the same level as Paraticinella eubejaouaensis and several Aptian hedbergellids species. Guembelitria sergipensis Koutsoukos is triserial throughout and it has more inflated chambers and a distinctly higher, pointed spire.

Etymology. Named for Blake Nose, a promontory on Blake Plateau, which is the only location where the species has been identified.

Phylogenetic relationships. It is not clear what species should be considered as ancestral to Ps. blakenosensis although it is likely to be a species of Hedbergella; a descendant is not presently known.

Stratigraphic range. From the $H d$. infracretacea Zone through Pa. eubejaouaensis Zone (upper Aptian) at Site 1049 on Blake Nose (Figs. 6, 7; Table 1).

Geographic distribution. Found only in the upper Aptian of ODP Site 1049 on Blake Nose (subtropical western North Atlantic).

Repository. Holotype (USNM 540915) and paratypes (USNM 540916, 540917) deposited at the Smithsonian Museum of Natural History, Washington, D.C.
Stable isotope paleobiology. Recorded with $\delta^{18} \mathrm{O}$ values that are comparable to co-occurring benthic species and $\delta^{13} \mathrm{C}$ values that are similar to co-occurring planktic species, indicating growth in a relatively deep planktic habitat or peak reproduction during cooler seasonal temperatures (Fig. 8; Table 5).

Family Hedbergellidae Loeblich and Tappan, 1961

Subfamily Hedbergellinae Loeblich and Tappan, 1961

Genus Hedbergella Brönnimann and Brown, 1958

Type species: Anomalina lorneiana d'Orbigny var. trocoidea Gandolfi, 1942.

Blefuscuiana Banner and Desai, 1988, p. 154-156.

Emended description. Test wall microperforate to finely perforate, outer wall weakly to densely covered with perforation cones or perforation ridges (coalescing perforation cones), never with an imperforate or keeled peripheral margin or with muricae and rarely with small, blunt pustules. Test small to relatively large in size, coiled in a low to moderately high trochospire with a rounded equatorial periphery, umbilicate; chambers globular to ovate, four to nine in the final whorl; umbilical and spiral sutures depressed, radial, straight to slightly curved; aperture an interiomarginal extraumbilical-umbilical arch with a thin imperforate rim or in rare cases a narrow bordering lip.

Remarks. Hedbergella was originally defined for Cretaceous trochospiral species that lack reticulate or meridional 


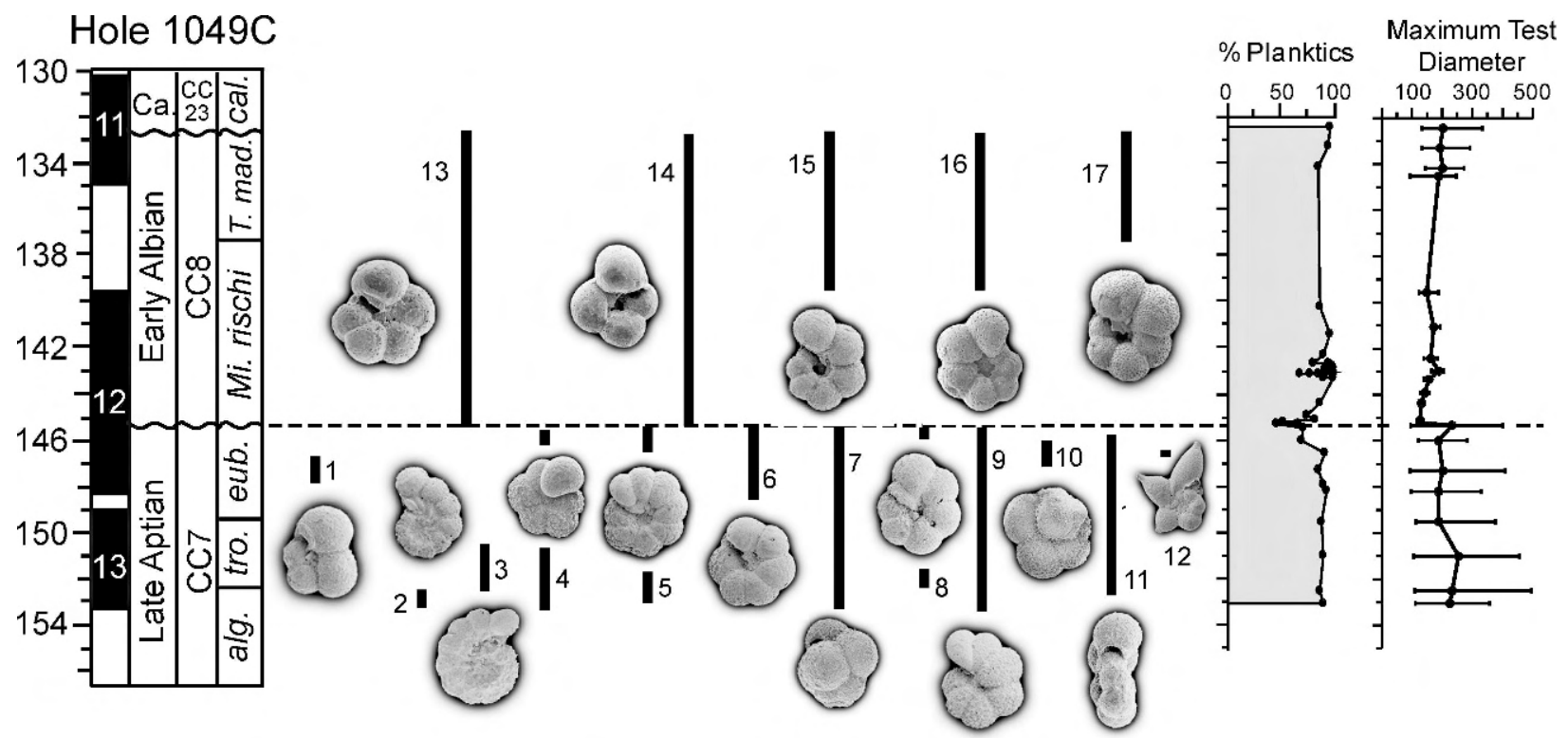

FIGURE 7. Biostratigraphic ranges, percent planktic foraminifera, and mean, maximum and minimum test diameter for planktic species across the Aptian/Albian boundary interval in ODP Hole 1049C. See caption of Figure 3 for explanation of core depth, core recovery, and biozones and see Table 1 for percent planktic data. Numbered specimens: (1) Praehedbergella umbilispira (1049C-12X-5, 121-122 cm); (2) Globigerinelloides algerianus (1049C-13X-CC); (3) Pseudoplanomalina cheniouriensis: 1049C-13-2, 100-102 cm; (4) Hedbergella infracretacea (1049C-12X-6, 10-11 cm); (5) Paraticinella eubejaouaensis (1049C-12X-5, 121-122 cm); (6) Paraticinella transitoria (1049C-12X-5, 121-122 cm); (7) Pseudoguembelitria blakenosensis n. sp. (1049C-12X-5, 0-2 cm); (8) Hedbergella occulta (1049C-12X-6, 129-130 cm); (9) Hd. trocoidea (1049C-13X-3, 60-62 cm); (10) Hd. gorbachikae (1049C-12X-5, 0-2 cm); (11) Globigerinelloides aptiensis (1049C-12X-6, 129-131 cm); (12) Schackoina cepedai (1049C-12X-5, 121$122 \mathrm{~cm})$; (13) Microhedbergella rischi (1049C-12X-3, 39-41 cm); (14) Mi. renilaevis (1049C-12X-3, 39-41 cm); (15) Mi. praeplanispira (1049C-11-4, 47.5-49.5 cm); (16) Mi. pseudoplanispira (1049C-11X-2, 124-126 cm); (17) Ticinella madecassiana (1049C-11X-2, 124-126 cm).

patterns of ornamentation, lack a keeled or imperforate equatorial periphery, and have an umbilical-extraumbilical primary aperture but no supplementary apertures. Because of its relatively simple morphology, few features have been identified for distinguishing between species of Hedbergella and, as a result, its evolution has been considered as slow. However, taxonomic descriptions of hedbergellids have traditionally overlooked the importance of wall microstructure, which is a primary feature used to classify modern and Cenozoic planktic foraminifera (Steineck and Fleisher, 1978; Hemleben and others, 1989; Olsson and others, 1999; Pearson and others, 2006). The extinction of several hedbergellid species bearing a distinct perforation cone wall architecture across the Aptian/Albian boundary and their replacement first by tiny, smooth-walled, microperforate species in the early Albian, and then by larger, finely perforate species in the middle Albian (Figs. 1, 4, 9), indicates that wall microstructure must be given higher taxonomic importance for distinguishing phylogenetic lineages within the Hedbergellidae. In addition, upper Aptian taxa typically lack a lip, while taxa of Albian and younger strata typically have a lip or apertural flap.

Scanning electron micrographs of the lectotype of $H d$. trocoidea (Gandolfi, 1942) (http://portal.chronos.org/ gridsphere/gridsphere?cid=res_taxondb), which is the type species of Hedbergella Brönnimann and Brown 1958, reveal faint perforation cones (sensu Banner and others, 1993), although the shell is too poorly preserved for detailed characterization of its primary wall microstructure. The wall surface of well-preserved $H d$. trocoidea (Figs. 10.1, 10.3; Premoli Silva and others, 2009, pl. 1, figs. 4d, 4e) is densely covered with perforation cones or weakly organized perforation ridges containing pores ranging $1.0-2.1 \mu \mathrm{m}$ in diameter.

Verga and Premoli Silva (2003) noted that perforation cones have been accorded quite different degrees of taxonomic significance by previous authors. For example, Jenkins and others (1998) used the presence/absence of perforation cones (also referred to as pore-mounds) as the primary criterion for distinguishing the triserial planktonic genus Guembelitria from Jenkinsina, whereas Banner and others (1993) had applied this wall microstructure at only the subspecies level and it was obliquely mentioned as an additional character that may appear in species of the planispiral genus Globigerinelloides. Because perforation cones are distinctly present on the type species of Hedbergella and are variably expressed on a number of hedbergellid species that range up to, but not above, the Aptian/Albian boundary (Figs. 5.3, 5.5-5.12, 11.1-11.9), their presence is considered a key wall-texture feature that phylogenetically links species included within Hedbergella.

Gorbatchik and Moullade (1973) designated Praehedbergella as a trochospiral subgenus of Clavihedbergella and distinguished it from the latter genus by the absence of radial chamber elongation. These authors considered Praehedbergella to be a thinner-walled, more finely perforate homologue of Hedbergella. However, Loeblich and Tappan (1987) did not consider wall microstructure as an important distinguishing feature for the hedbergellids and, as a result, they synonymized Praehedbergella under Hedbergella. Banner and Desai (1988) resurrected Praehedbergella by implicitly limiting its definition to include only 


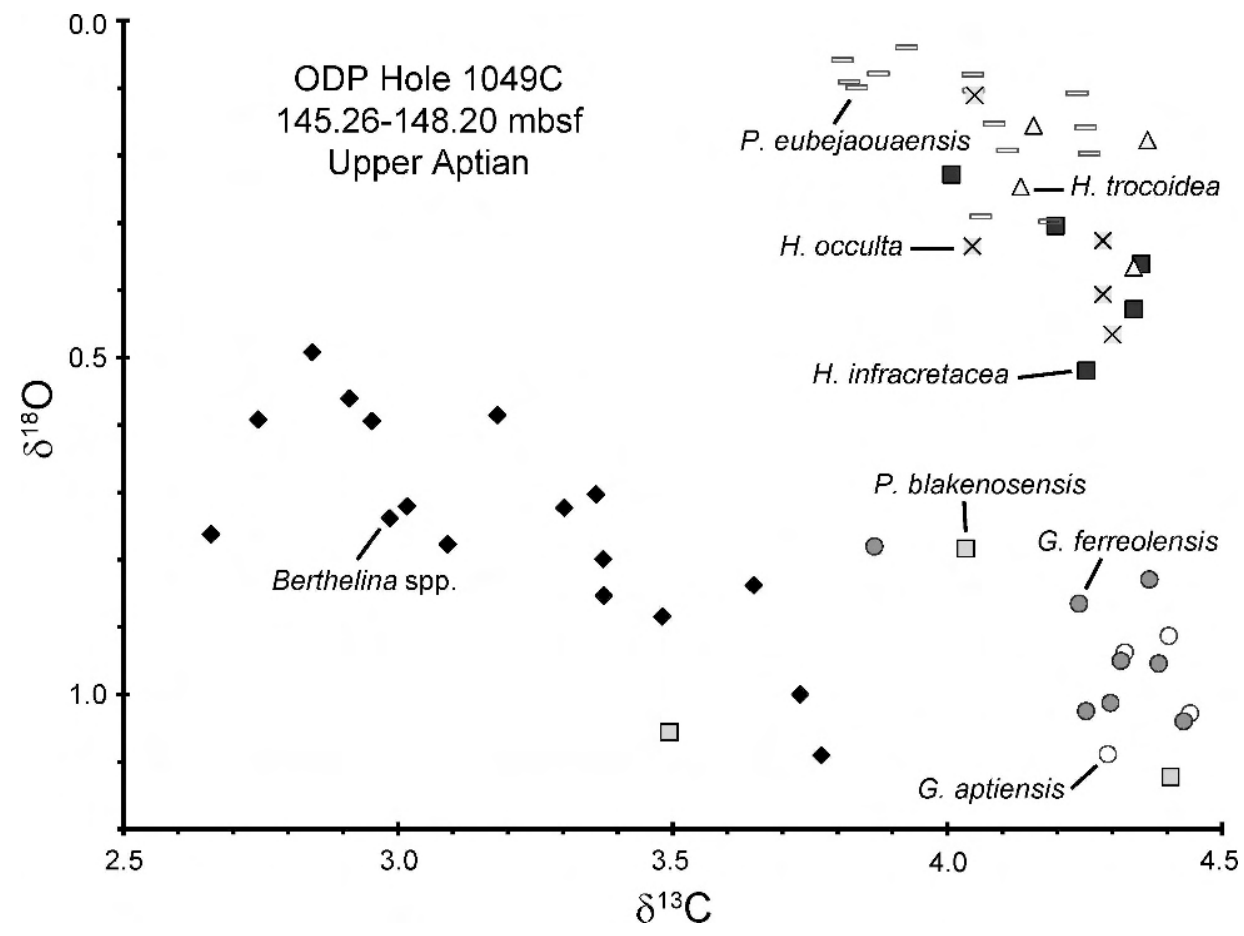

FIGURE 8. Oxygen and carbon isotope cross-plot of late Aptian foraminifera from between 148.20 and 145.26 mbsf of ODP Hole 1049C. Benthic foraminifera are represented by diamond symbols for Berthelina spp. while planktic foraminifera are represented by all other symbols.

trochospiral forms with $4.0-4.5$ chambers in the last whorl, in contrast to their new genus Blefuscuiana, which they defined as having $5-8$ chambers in last whorl. Banner and others (1993) formally emended the definition of Praehedbergella to include forms with 4-5 chambers visible in the dorsal view, but with only 4 chambers bordering the ventral umbilicus and they included smooth-walled microperforate taxa along with taxa bearing perforation cones. Moullade and others (2002) disagreed with the Banner and others (1993) emendation because they did not consider the number and shape of chambers to be useful for taxonomic discrimination at the genus level. The former authors reaffirmed Gorbatchik and Moullade's (1973) wall-microstructure distinction between Praehedbergella and Hedbergella, but we emphasize that detailed microstructure and stratophenetic study are needed to better understand phylogenetic relationships within and between both genera.

Species included. Hedbergella aptiana Bartenstein, Hd. excelsa Longoria, $\mathrm{Hd}$. gorbachikae Longoria, $\mathrm{Hd}$. hispaniae Longoria, $\mathrm{Hd}$. infracretacea (Glaessner), $\mathrm{Hd}$. occulta Longoria, Hd. praetrocoidea Kretzchmar and Gorbachik, $H d$. ruka (Banner, Copestake and White), and Hd. trocoidea (Gandolfi).

Stratigraphic range. Hauterivian through upper Aptian. Geographic distribution. Cosmopolitan.

\section{Hedbergella aptiana Bartenstein, 1965}

$$
\text { Figs. 5.6, } 5.7
$$

?Globigerina sp. D9 Hecht, 1938, p. 17, pl. 23, figs. 60-63. Hedbergella aptiana Bartenstein, 1965, p. 347, 348, text-figs. 4-6. Blefuscuiana occulta (Longoria) quinquecamerata Banner and Desai, 1988, p. 162, 163, pl. 7, figs. 9-11.

Hedbergella delrioensis (Carsey), Leckie, 1984, p. 598, pl. 1, fig. 12 [Not pl. 9, figs. 1-4, 8].
Emended description. Test wall finely perforate, pores widely dispersed and surrounded by small perforation cones, surface mostly smooth. The shell may have fine pustules concentrated in umbilical region. Test medium in size, coiled in $2-2.5$ whorls with a flat to low trochospire; 5-5.5 globular to subglobular chambers in the final whorl, increasing moderately in size; equatorial periphery elliptical, moderately lobate; sutures depressed, radial to slightly curved; umbilicus shallow, moderately wide; aperture a low to medium extraumbilical arch with a thin imperforate rim and without any periapertural structures.

Remarks. Although Hd. aptiana was not described as having perforation cones, and Banner and others (1993) explicitly noted their absence, SEM observation of well preserved specimens reveals their faint expression on all but the last of the final whorl chambers (Fig. 5.6). Absence of any periumbilical structures is apparent on the wellpreserved specimens.

Hedbergella aptiana differs from $\mathrm{Hd}$. occulta by having faster chamber growth rate, lacking deeply incised umbilical sutures, and lacking an apertural lip. It differs from $H d$. infracretacea by having a smoother test surface and a faster growth rate of the chambers.

Stratigraphic range. In their study of Rio Argos sections in southern Spain, Coccioni and Premoli Silva (1994) recorded the LO of $\mathrm{Hd}$. aptiana in the Barremian. Its range in the North Sea was recorded by Banner and others (1993) as Barremian ( $\mathrm{Hd}$. similis Zone) through upper Aptian ( $\mathrm{Pa}$. eubejaouaensis Zone). At Site $511 \mathrm{Hd}$. aptiana ranges to within $0.67 \mathrm{~m}$ below the Aptian/Albian boundary (Fig. 8; Table 2).

Geographic distribution. Cosmopolitan. 


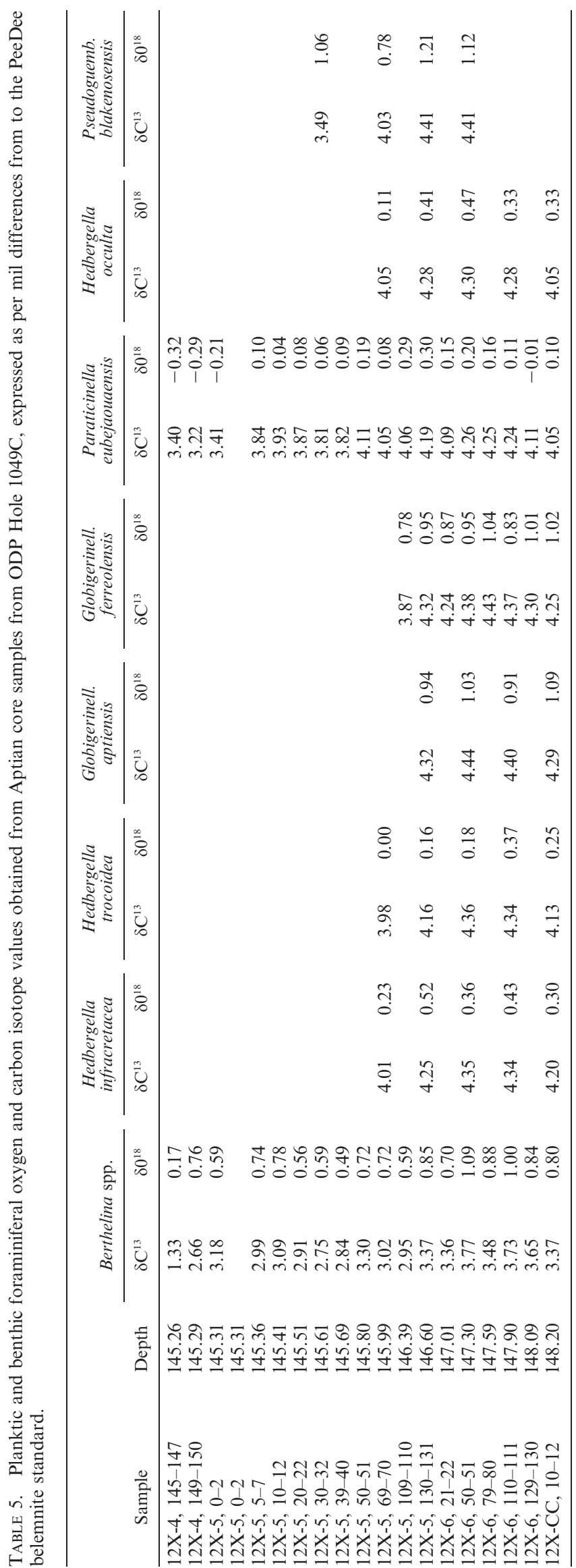

Hedbergella excelsa Longoria, 1974

Figs. 11.8-11.10

Hedbergella excelsa Longoria, 1974, p. 55, 56, pl. 18, figs. 6-8, 9-11, $14-16$.

Hedbergella aff. H. trocoidea Leckie, 1984, p. 599, pl. 3, figs. 5-10 [upper Aptian, DSDP Site 545, eastern North Atlantic].

Hedbergella aff. H. trocoidea Leckie, 1990, p., pl. 31, figs. 14-17 [upper Aptian, ODP Hole 693A, Antarctic margin].

Blefuscuiana excelsa cumulus Banner, Copestake and White, 1993, p. 11, pl. 6, figs. 1a-c, 2a-c.

Emended description. Test wall finely perforate, covered by weakly developed perforation cones. Test small to medium in size, coiled in a moderate to high trochospire with 2-2.5 whorls; 4.5-6 chambers in the final whorl, increasing gradually in size, chambers globular to subglobular; equatorial periphery circular to subcircular, moderately lobate; sutures depressed, radial to slightly curved; umbilical area narrow and moderately deep; aperture an umbilical-extraumbilical low to medium arch with an imperforate rim but without a bordering lip or other periapertural structures.

Remarks. Athough the aperture on the holotype of this species is obscured and the original wall texture is not preserved, well preserved specimens reveal that the aperture is not bordered by a lip or flap and the wall is covered by small-sized perforation cones.

Hedbergella excelsa differs from $H d$. infracretacea by having a higher trochospire and more weakly developed perforation cones. Hedbergella ruka is similar to H. excelsa in spire height but has a narrower umbilicus and only 4 chambers in the final whorl.

Stratigraphic range. Lower Aptian (Globigerinelloides blowi Zone; Coccioni and Premoli Silva, 1994) through upper Aptian (upper Paraticinella eubejaouaensis Zone; this study).

Geographic distribution. Considered cosmopolitan, though it was is conspicuously absent from Site 1049.

\section{Hedbergella gorbachikae Longoria, 1974} Figs. 5.3, 5.5

Hedbergella gorbachikae Longoria, 1974, p. 56-58, pl. 15 figs. 11-13 [upper Aptian, La Boca Canyon, Monterrey, Mexico].

Hedbergella gorbachikae Longoria, Leckie, 1984, p. 598, pl. 4, figs. 9 11 [upper Aptian, DSDP Site 545, Mazagan Plateau, eastern North Atlantic].

Not Hedbergella gorbachikae Longoria, Caron, 1978, pl. 3, figs. 9-12 [middle Albian, DSDP Site 364, Angola Basin, eastern South Atlantic].

Emended definition. Test wall finely perforate, smooth with moderately to strongly developed perforation cones on most chambers of the last whorl. Test medium in size, equatorial periphery subcircular to slightly ovoid, slightly to moderately lobate, $2-2.5$ whorls coiled in a flat to slightly convex trochospire; chambers globular to subglobular, inflated, increase gradually in size, $4.5-5.5$ in the final whorl with the last two or three tending to become subrounded to subtriangular on the umbilical side, subtrapezoidal on the spiral side, reniform in edge view, last chamber protruding into the umbilicus and partly or completely covering it; sutures depressed, radial and straight; umbilical area small and deep. Aperture a low to medium arch, which may be bordered by an imperforate rim. 


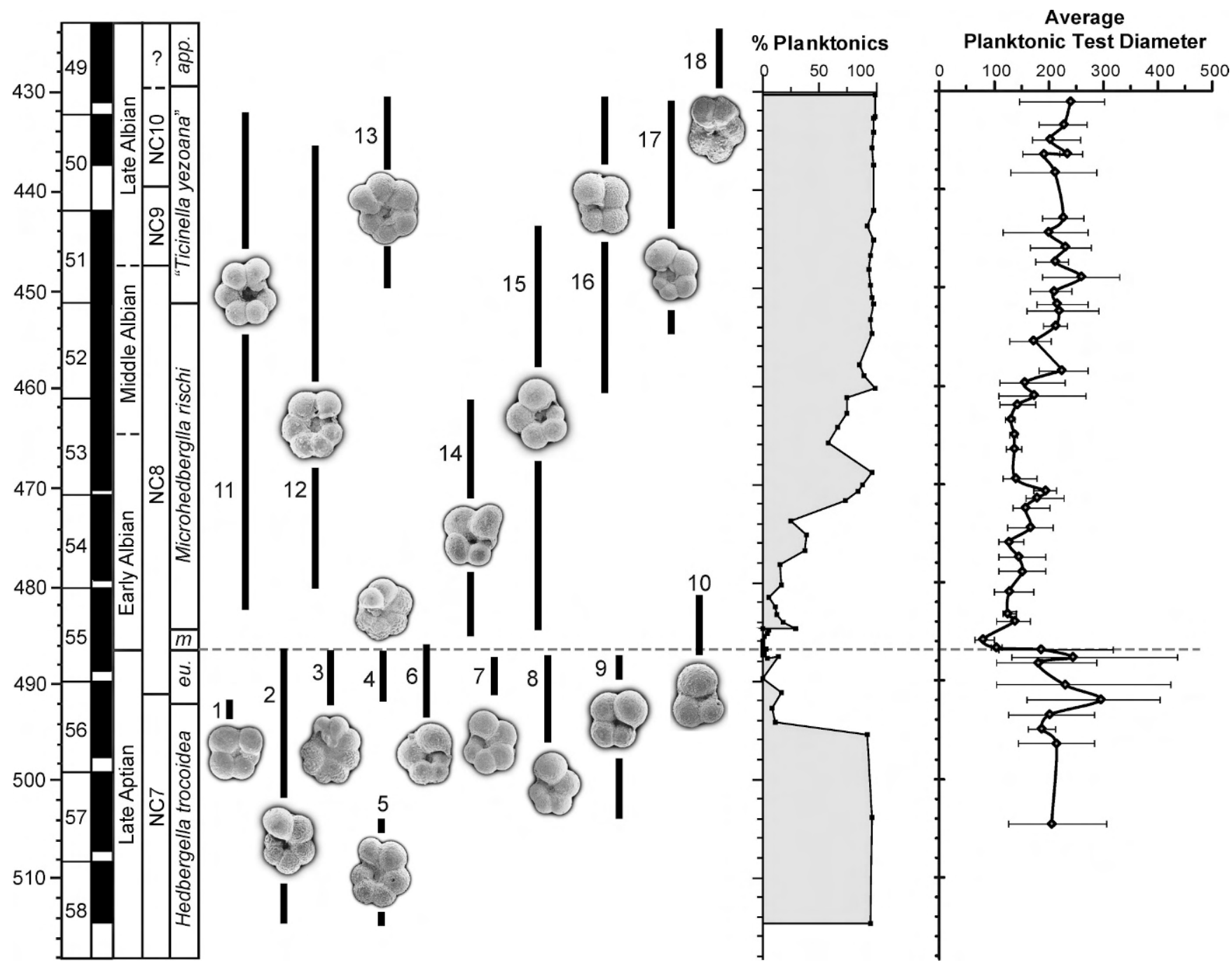

FIGURE 9. Biostratigraphic ranges, percent planktic foraminifera, and mean, maximum and minimum test diameter for planktic species across the Aptian/Albian boundary interval in at DSDP Site 511. See caption of Figure 3 for explanation of core depth, core recovery, and biozones. Species illustrated with their ranges are from the following samples: (1) Hedbergella gorbachikae (511-55-2, 100-101 cm); (2) Hedbergella infracretacea (51156-2, 23-25 cm); 3) Paraticinella eubejaouaensis (511-56-2, 23-25 cm); (4) Paraticinella transitoria (511-56-2, 23-25 cm); (5) Hedbergella occulta (51157-4, 38-52 cm), (6) Hedbergella praelippa (511-55-6, 20-22 cm); (7) Hedbergella excelsa (511-56-2, 23-25 cm); (7) Hedbergella excelsa (511-56-2, 23$25 \mathrm{~cm})$; (8) Hedbergella aptiana (511-55-5, 121-123 cm); (9) Hedbergella ruka (511-55-5, 131-133 cm); (10) Microhedbergella miniglobularis (511-55-5, 99-100 cm); (11) Microhedbergella praeplanispira (511-52-4, 70-72 cm); (12) Microhedbergella pseudoplanispira (511-52-2, 136-138 cm); (13) Microhedbergella trans. Muricohedbergella planispira (511-50-2, 29-33 cm); (14) Microhedbergella renilaevis (511-55-1, 24-26 cm); (15) Microhedbergella rischi (511-54-1, 22-24 cm); (16) Microhedbergella pseudodelrioensis (511-50-3, $26-28 \mathrm{~cm})$; (17) "Ticinella yezoana" (511-49-6, $24-26 \mathrm{~cm})$.

Remarks. This species shows considerable variability in the shape and breadth of the final chamber. Middle Albian specimens illustrated by Caron (1978, pl. 3, figs. 9-12; 1985, figs. $9 \mathrm{a}-\mathrm{c})$ have a morphology resembling $H d$. gorbachikae, but the absence of perforation cones and microperforate wall suggest these should be assigned to another taxon.

Stratigraphic range. Lower Aptian (Globigerinelloides blowi Zone) through upper Aptian (upper Paraticinella eubejaouaensis Zone).

Geographic distribution. Cosmopolitan.

\section{Hedbergella infracretacea (Glaessner, 1937)}

Figs. 5.8-5.12

Globigerina infracretacea Glaessner, 1937, p. 28, fig. 1 [Albian, northwest Caucasus Mountains].
Globigerina aptica Agalarova 1951, p. 49, pl. 8, figs. 9-11 [Aptian, Azerbbaijan].

Globigerina infracretacea Glaessner trochoidea Moullade, 1960, p. 136 , pl. 2, figs. 21, 23-25 [Aptian, Vocontian Basin, southeast France].

Globigerina infracretacea Glaessner gargasiana Moullade, 1961, p. 214 [Aptian, Vocontian Basin, southeast France].

Hedbergella beegumensis Marianos and Zingula, 1966, p. 335, pl. 37, figs. $7 \mathrm{a}-\mathrm{c}$.

Hedbergella aff. Hd. infracretacea (Glaessner), Leckie, 1990, p. 321, pl. 2, figs. 1-18 [upper Aptian, ODP Hole 693A, Antarctic margin].

Blefuscuiana aptiana (Agalarova) orientalis BouDagher-Fadel and others 1997 , p. 125 , 126, pl. 1.1., figs. 3, 4; pl. 8.2, figs. 9-11, pl. 8.3, figs. 1-8. Hedbergella infracretacea (Glaessner) occidentalis BouDagher-Fadel and others 1997, p. 129, pl. 8.7, figs. 9-15.

Emended description. Test wall relatively thick (4-6 $\mu \mathrm{m})$, finely perforate, most chambers in the final whorl are densely covered by perforation cones that may coalesce 


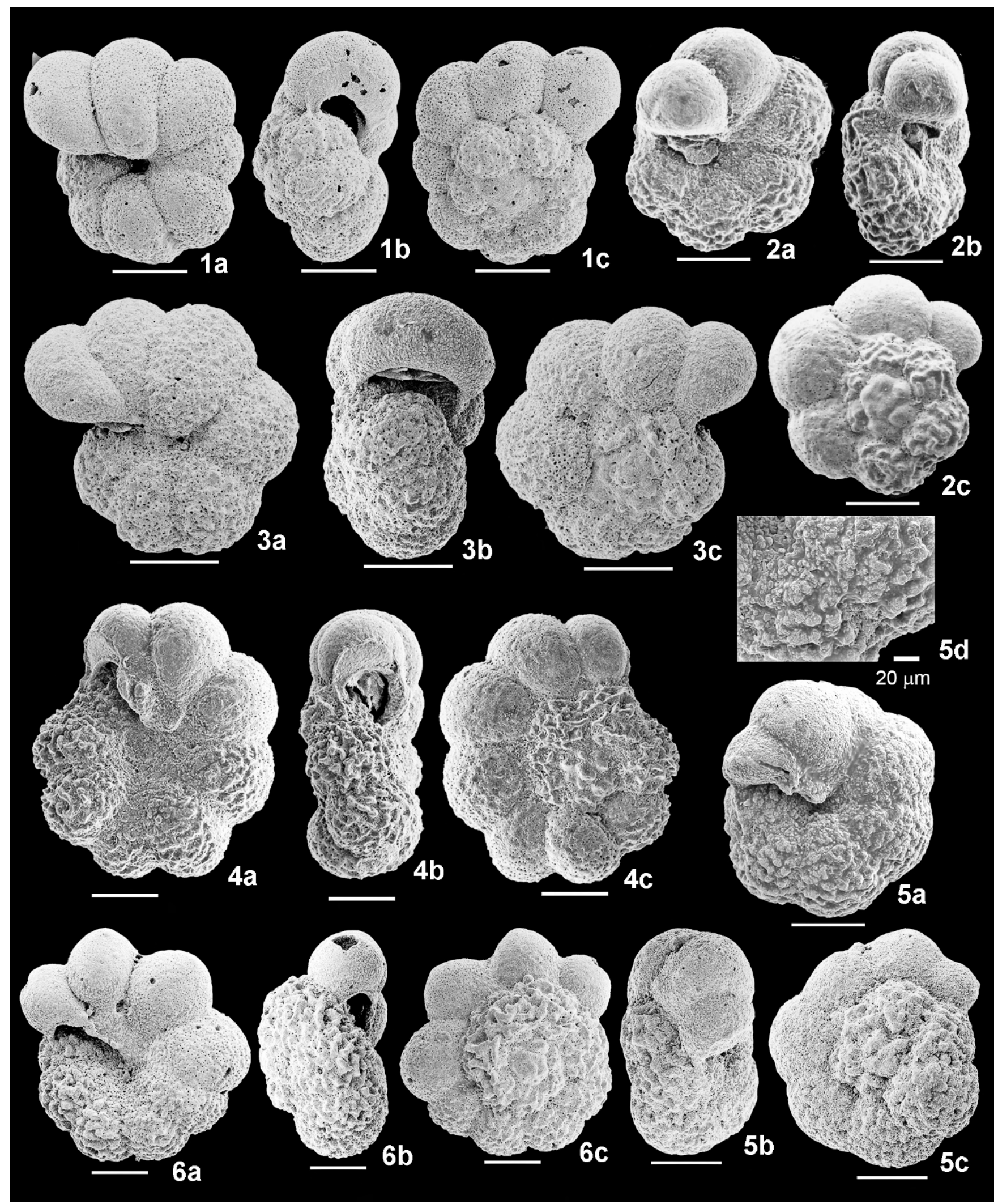

Figure 10. Late Aptian Hedbergella trocoidea, Paraticinella transitoria, and Paraticinella eubejaouaensis. Scale bars are $100 \mu \mathrm{m}$ unless shown otherwise. 1, $3 \mathrm{Hd}$. trocoidea, 1049C-13X-CC. 2, 5 Pa. transitoria; 2, 511-56-2, $23-25 \mathrm{~cm}$; 5, 545-41-4, 27-30 cm, including magnified view of fused muricate ridges near umbilical suture between third and fourth chambers of final whorl. 4, 6 Pa. eubejaouaensis, 4, 511-56-2, 23-25 cm; 6, 1049C-12X$6,129-131 \mathrm{~cm}$. 


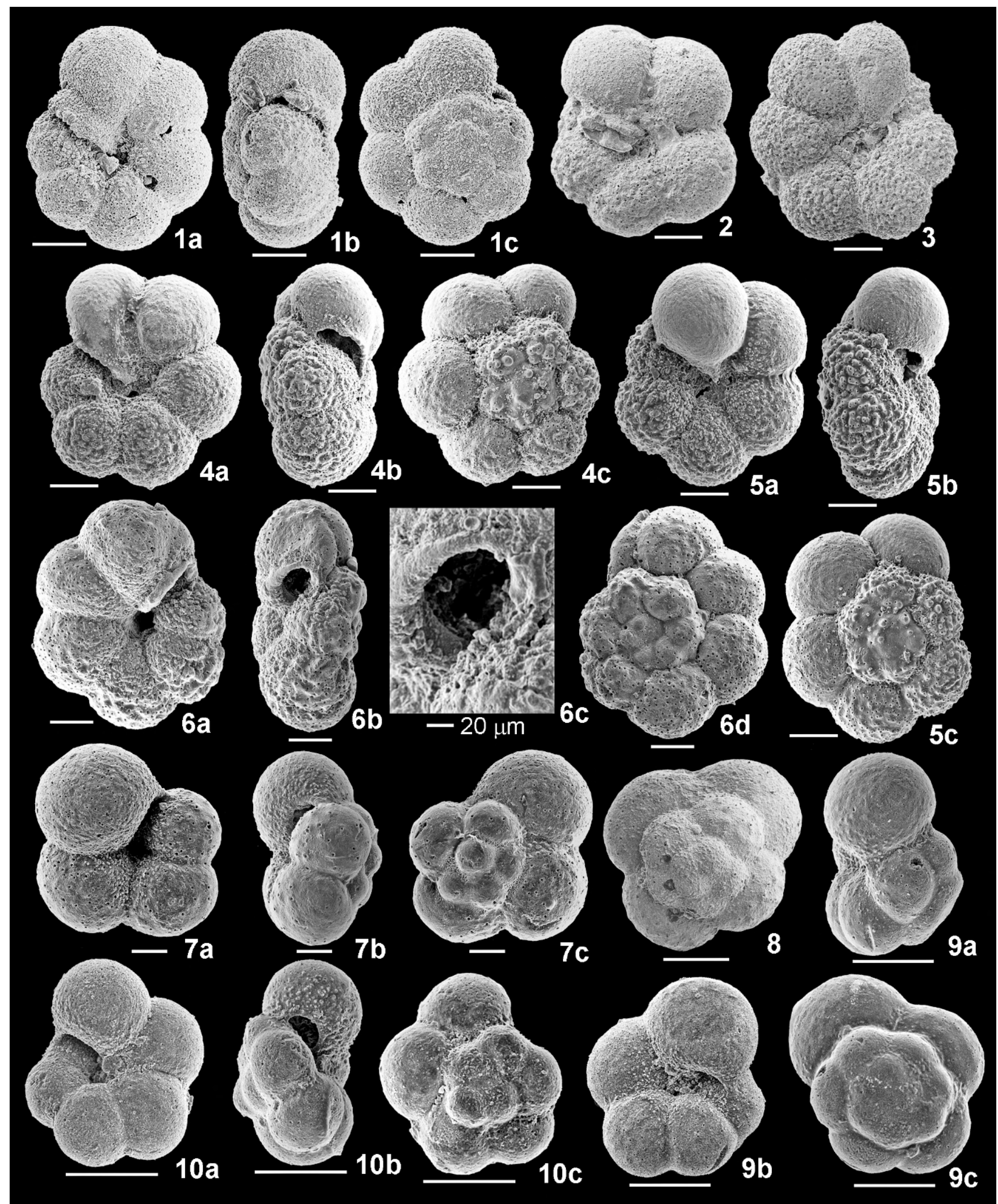

Figure 11. Late Aptian Hedbergella occulta, Hd. ruka, and Hd. excelsa. Scale bars are 50 m unless shown otherwise. 1-6 Hd. occulta: 1, 1049C12X-6, 129-131 cm; 2, 545-41-1, 40-42 cm; 3, 545-40-6, 63-65 cm; 4, 5, 511-57-4, 38-52 cm; 6, Hedbergella cf. Hd. occulta, 511-57-4, 38-52 cm, including, magnified view of apertural lip. 7, 8 Hd. ruka: 7, 511-55-5, 131-133 cm; 8, 511-55-6, 20-22 cm. 9, 10 Hd. excelsa: 9, 511-56-2, 23-25 cm; 10, 1049C-12X-5, 20-22 cm. 
(e.g., Fig. 5.9b), and internal chamber wall may also show slightly raised cones surrounding each pore (Fig. 4a). Test medium sized, coiled in a nearly flat to slightly convex trochospire with 2-2.5 whorls; 5-6 (rarely 4.5) globular to subglobular chambers in the final whorl, increasing gradually in size, never radially elongate, last chamber often kummerform; equatorial periphery subcircular to slightly ovoid, slightly to moderately lobate; sutures depressed, radial, mainly straight; umbilical area rather narrow and deep; aperture a low to medium umbilicalextraumbilical arch with a thin imperforate rim, but never bordered by a lip or other periapertural structures.

Remarks. Populations of Hedbergella infracretacea display considerable morphological variability in the number of chambers of the outer whorl (from 4.5-6), in the height of the dorsal side, which varies from almost flat to slightly convex, in the height and density of perforation cones on the chamber exterior, and in the chamber growth rate in the final whorl. Globigerina aptica Agalarova 1951, G. infracretacea Glaessner gargasiana Moullade 1961, Hd. beegumensis Marianos and Zingula 1966, Blefuscuiana aptiana (Agalarova) orientalis BouDagher-Fadel and others 1997, and Hd. infracretacea (Glaessner) occidentalis BouDagher-Fadel and others 1997 are all considered as junior synonyms that fall within this variability. Six-chambered forms of this species (e.g., Figs. 5.8, 5.10) resemble Hd. praetrocoidea Kretzchmar and Gorbachik 1986 except for the presence of an apertural lip and more faintly developed perforation cones in the latter species.

It is likely that reports of $\mathrm{Hd}$. delrioensis (Carsey) from the Aptian are misidentified specimens of $H d$. infracretacea since the general morphologies are similar (e.g., Longoria, 1974; Leckie, 1984), but Hd. delrioensis did not evolve until the late Albian (Moullade, 1966; Petrizzo and Huber, 2006), its wall texture is comprised of pustules that cannot be easily distinguished from perforation cones under the stereomicroscope, and presence or absence of an apertural lip has not been used by past workers to discriminate these species. Reports of $H d$. infracretacea from Albian sediments are also probably the result of misidentification as its extinction at the top of the Paraticinella eubejaouaensis Zone, which is at or near the top of the Aptian, is well documented at DSDP Sites 511 (Falkland Plateau) and 545 (Mazagan Plateau), and ODP Sites 763 and 1049 (see Revised Biostratigraphy section below).

Stratigraphic range. Coccioni and others (2007) record $H d$. infracretacea within the Hauterivian in southeastern France. This species becomes extinct in the uppermost Aptian, at the same level as the extinction of $\mathrm{Pa}$. eubejaouaensis.

Geographic distribution. Cosmopolitan.

Stable isotope paleobiology. Mixed-layer dweller, with very similar $\delta^{18} \mathrm{O}$ values to co-occurring $\mathrm{Hd}$. occulta, slightly greater than $\mathrm{Pa}$. eubejaouaensis and $\mathrm{Hd}$. trocoidea, and significantly more positive than Gl. ferreolensis and $\mathrm{Gl}$. aptiensis (Fig. 8; Table 5). Its $\delta^{13} \mathrm{C}$ values approximate those of $\mathrm{Hd}$. occulta, $\mathrm{Hd}$. trocoidea, Ps. blakenosensis, Gl. ferreolensis, and Gl. aptiensis and are slightly more positive than co-occurring Pa. eubejaouaensis.
Hedbergella occulta Longoria, 1974

Figs. 11.1-11.6

Hedbergella occulta Longoria, 1974, p. 63, 64, pl. 11, figs. 1-3, 7, 8, pl. 20, figs. 5-7, 8, 9, 17, 18 [early Aptian, Sierra Madre, northern Mexico].

Hedbergella sp. 1 Leckie, 1984, p. 599, pl. 4, figs. 5-8, 12 [upper Aptian, DSDP Site 545, eastern North Atlantic].

Hedbergella cf. H. rischi Moullade, Leckie, 1984, p. 599, pl. 7, figs. 11, 12 [uppermost Aptian, DSDP Site 545, eastern North Atlantic].

Blefuscuiana globigerinelloides (Subbotina) lobulata Banner and Desai 1988, p. 164, pl. 6, figs. 1-3 [lower Aptian, Speeton Cliff, UK].

Blefuscuiana occulta perforocculta Banner, Copestake and White, 1993, p. 13, 14, pl. 8, figs. 2a-c, 3 [lower Aptian, central North Sea].

Emended description. Test wall finely perforate, surface sometimes smooth, but usually covered by perforation cones except for the final chamber, which is usually smooth. Test is medium in size, coiled in a low trochospire with 2 2.5 whorls; equatorial periphery subcircular to ovoid, slightly lobate; chambers increasing gradually in size with 6-6.5 in the outer whorl, globular until the last one or two chambers, which become subtriangular on the umbilical side; final chamber may be kummerform or aborted; sutures depressed, radial to slightly curved; umbilical area moderately narrow and deep; aperture a low to medium arch bordered by a narrow to thick lip.

Remarks. Hedbergella occulta displays variability in the coarseness of the wall surface texture, the tightness of coiling, degree of lip development, and the shape and lobateness of the peripheral outline, which varies from subcircular to ovoid and weakly to moderately lobate. Hedbergella occulta differs from $H d$. trocoidea in having fewer and less-embracing chambers (6-6.5 compared with 6.5-8); it differs from both $H d$. trocoidea and $H d$. praetrocoidea in possessing an apertural lip and in having a thinner test. It differs from $H d$. infracretacea, Hd. aptiana, and $H d$. excelsa by the presence of an apertural lip and by having 6-6.5 rather than fewer chambers in the final whorl. It is further distinguished from $H d$. excelsa in having a low trochospire. It differs from Hd. primare Kretzchmar and Gorbachik 1986 by having a narrower umbilicus and stronger expression of perforation cones. Nonetheless, similarity in test morphology may suggest a phylogenetic relationship between these two species.

Stratigraphic range. Lower Aptian (Globigerinelloides blowi Zone) through upper Aptian (Paraticinella eubejaouaensis Zone).

Geographic distribution. Cosmopolitan.

Stable isotope paleobiology. Mixed-layer dweller, with very similar $\delta^{18} \mathrm{O}$ values to co-occurring $H d$. infracretacea, slightly greater than $\mathrm{Pa}$. eubejaouaensis and $\mathrm{Hd}$. trocoidea, and significantly more positive than $G l$. ferreolensis and $G l$. aptiensis (Fig. 8). Its $\delta^{13} \mathrm{C}$ values approximate those of $H d$. infracretacea, $\mathrm{Hd}$. trocoidea, Ps. blakenosensis, Gl. ferreolensis, and Gl. aptiensis and are slightly more positive than co-occurring Pa. eubejaouaensis.

\section{Hedbergella praelippa Huber and Leckie, n. sp.} Figs. 12.1-12.5

Description. Test wall microperforate with randomly distributed pores, pore diameter ranging $0.6-0.8 \mu \mathrm{m}$, surface smooth or with weakly developed perforation cones. Test very small, coiled in a low to rarely moderate trochospire, equatorial periphery moderately lobate, equal- 


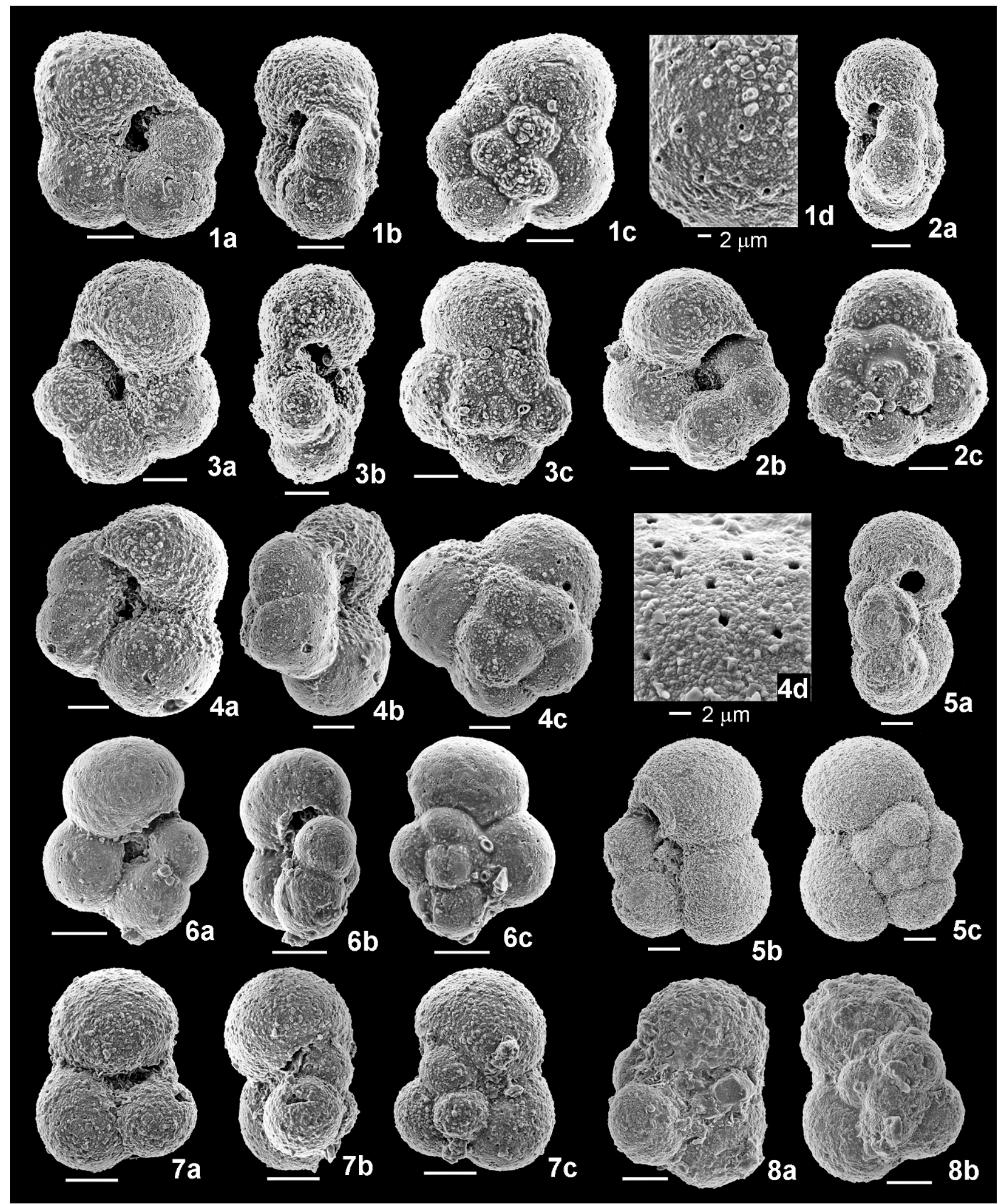

FIGURE 12. Hedbergella praelippa, n. sp. and Mi. miniglobularis, n. sp. from the uppermost Aptian. Scale bars $=20 \mu \mathrm{m}$ unless shown otherwise. $1-$ $5 \mathrm{Hd}$. praelippa: 1, holotype USNM 540918, 511-55-6, 20-22 cm, showing surface of umbilical side of penultimate chamber with perforation cones around microperforate pores; 2, paratype USNM 540919, 511-56-2, 23-25 cm; 3, paratype USNM 540920, 511-55-6, 20-22 cm; 4, 511-55-6, 20-22 cm, showing surface of umbilical side of antepenultimate chamber; 5, 1049C-12X-5, 121-122 cm. 6-8 Mi. miniglobularis: 6, paratype USNM 540922, 511$55-5,99-100 \mathrm{~cm} ; 7,511-55-5,99-100 \mathrm{~cm} ; 8$, Pré-Guittard PG-12. 
ly biconvex, test thickness:diameter ratio averaging 0.55 ; chambers subgobular to globular, dextrally, or sinistrally coiled in a low trochospire consisting of 2 whorls of 8-9 chambers that increase rapidly in size, ultimate:penultimate ratio averaging 1.14 , antepentultimate:ultimate ratio averaging 1.3 , with $4.0-4.5$ chambers in the final whorl, final chamber face extends in the direction of coiling; sutures moderately depressed, radial, straight; umbilicus shallow, narrow, umbilical: test diameter ratio averaging 1.4; aperture an extra-umbilical low arch that extends from near the peripheral margin into the umbilicus, without a bordering lip. Holotype: maximum diameter $101 \mu \mathrm{m}$, thickness $52 \mu \mathrm{m}$, proloculus $21 \mu \mathrm{m}$. Paratypes and hypotypes: diameter ranging 102-112 $\mu \mathrm{m}$ and averaging $105 \mu \mathrm{m}$, proloculus ranging $20-23 \mu \mathrm{m}$ and averaging $22 \mu \mathrm{m}$.

Remarks. This species is placed in Hedbergella because of the presence of perforation cones (Figs. 12.1d, 12.4d) and absence of an apertural lip or flap. It is distinguished from other Aptian species by its small size, tightness of coiling, relatively rapid chamber size increase, and forward extension of the final chamber face near the peripheral margin. The latter character, plus its tiny size are the principal are features used to distinguish $H d$. praelippa from $H d$. ruka. It is distinguished from Albian species of Microhedbergella by the presence of perforation cones and absence of an apertural lip. Hedbergella praelippa is similar to Praehedbergella sigali (Moullade, 1966), but the latter species is more lobate, its chamber face does not show a forward extension, and it lacks perforation cones on its wall surface.

Etymology. Prefix "prae" (Latin) meaning "before" is added to "lippa" (Old English) meaning "lip".

Phylogenetic relationships. Possibly descended from $H d$. excelsa or $H d$. ruka, though Praehedbergella sigali must also be considered as a possible ancestor if the stratigraphic range of $\mathrm{Hd}$. praelippa is found to extend into older Aptian sediments; probable ancestor of Microhedbergella miniglobularis n. sp. (Fig. 13).

Stratigraphic range. At Site 511 its LO is within the upper Aptian, just below the base of the Pa. eubejaouaensis Zone, and its $\mathrm{HO}$ is within the lowermost Albian, $0.7 \mathrm{~m}$ above the base of the Mi. miniglobularis Zone (Figs. 9, 14; Table 2). The total range of this species needs to be further determined from study of other sites.

Geographic distribution. Identified at DSDP Site 511 (southern South Atlantic) and ODP Site 1049 (western subtropical North Atlantic), and ODP Site 763 (southeast Indian Ocean).

Repository. Holotype (USNM 540918) and paratypes (USNM 540919, 540920) deposited at the Smithsonian Museum of Natural History, Washington, D.C.

\section{Hedbergella ruka (Banner, Copestake and White, 1993)} Figs. 11.7, 11.8

Praehedbergella ruka Banner, Copestake and White, 1993, p. 6, pl., 1, figs. 2a-c [early Aptian, central North Sea].

Praehedbergella ruka contritus Banner, Copestake and White, 1993, pl. 1, figs. 3a-c, 4a, b [late Aptian, central North Sea].

Praehedbergella ruka papillata Banner, Copestake and White, 1993, pl. 1, figs. 5a-c [early Aptian, central North Sea].

Emended description. Test wall smooth, finely perforate, pores evenly distributed, surface with small perforation cones on all but the final adult chamber. Test small to medium, coiled in a moderately high trochospire with 2-2.5 whorls; chambers increasing moderately in size as added with about 5 in the early whorl and 4 in the final whorl, chambers globular, inflated; equatorial periphery rounded, lobate; sutures depressed, radial and straight; umbilical area narrow and deep; aperture a low-umbilical to extraumbilical arch with thin imperforate rim, but without a bordering lip or other periapertural structures.

Remarks. This species is characterized by its moderate trochospire, strongly inflated chambers, and compact, quadrate equatorial periphery. It differs from other Aptian hedbergellids by its 4-chambered morphology and strong convexity of the dorsal side. Hedbergella ruka is larger than Hd. praelippa and it has more globular (spherical) chambers and its aperture does not extend quite as far to the peripheral margin as in $\mathrm{Hd}$. praelippa. Hedbergella ruka is distinguished from $H d$. excelsa by its fewer (4) chambers in the final whorl.

Stratigraphic range. In the North Sea region, Banner and others (1993) record morphotypes of this species as ranging lower through upper Aptian.

Geographic distribution. Cosmopolitan.

\section{Hedbergella trocoidea (Gandolfi, 1942)}

Figs. 10.1, 10.3

Anomalina lorneiana var. trocoidea Gandolfi, 1942, p. 99, 134, pl. 2, fig. 1a-c, pl. 4, figs. 2, 3, pl. 13, figs. 2, 5 [Aptian, top of Biancone Limestone, southeastern Switzerland].

Hedbergella trocoidea (Gandolfi), Dupeuble, 1979, pl. 2, figs. 4-6 [upper Aptian, DSDP Hole 400A, Bay of Biscay, eastern North Atlantic].

Hedbergella trocoidea (Gandolfi), Leckie, 1984, p. 599, pl. 3, figs. 1-4 [upper Aptian, DSDP Site 545, Mazagan Plateau, eastern North Atlantic].

Hedbergella trocoidea (Gandolfi), Premoli Silva and others, 2009, textfigs. 3-1, 3-2, pl. 2, figs. 7, 8. [upper Aptian, DSDP Site 545, Mazagan Plateau, North Atlantic].

Emended description. Wall finely perforate with randomly distributed perforation cones that are larger in the early chambers, becoming less distinct on the later chambers, never coalescing to form rugosities or ridges. Test medium to large, trochospirally coiled in 2-2.5 whorls, equatorial outline rounded, subcircular to ovoid, slightly lobate, dorsal side nearly flat to slightly convex; 6.5-8 chambers in the final whorl that increase gradually in size; chamber shape subtriangular to triangular on the umbilical side, subspherical to trapezoidal on the spiral side, may be reniform in lateral view; sutures depressed, radial to slightly curved; umbilical area small and rather deep; aperture a low to medium arch without a lip.

Remarks. Hedbergella trocoidea differs from its ancestor Hd. praetrocoidea BouDagher-Fadel and others (1997) in having more numerous chambers in the outer whorl (6.57.5 instead of 5.5-6.5) and a smaller and deeper umbilical area, and in having more embracing chambers. Differences from its descendant Paraticinella eubejaouaensis are summarized in the remarks for $\mathrm{Pa}$. eubejaouaensis below.

Genus Microhedbergella Huber and Leckie, n. gen. Type species: Microhedbergella renilaevis Huber and Leckie, n. sp.

Description. Test wall thin, microperforate, becoming finely perforate in the late early Albian, wall pores evenly 


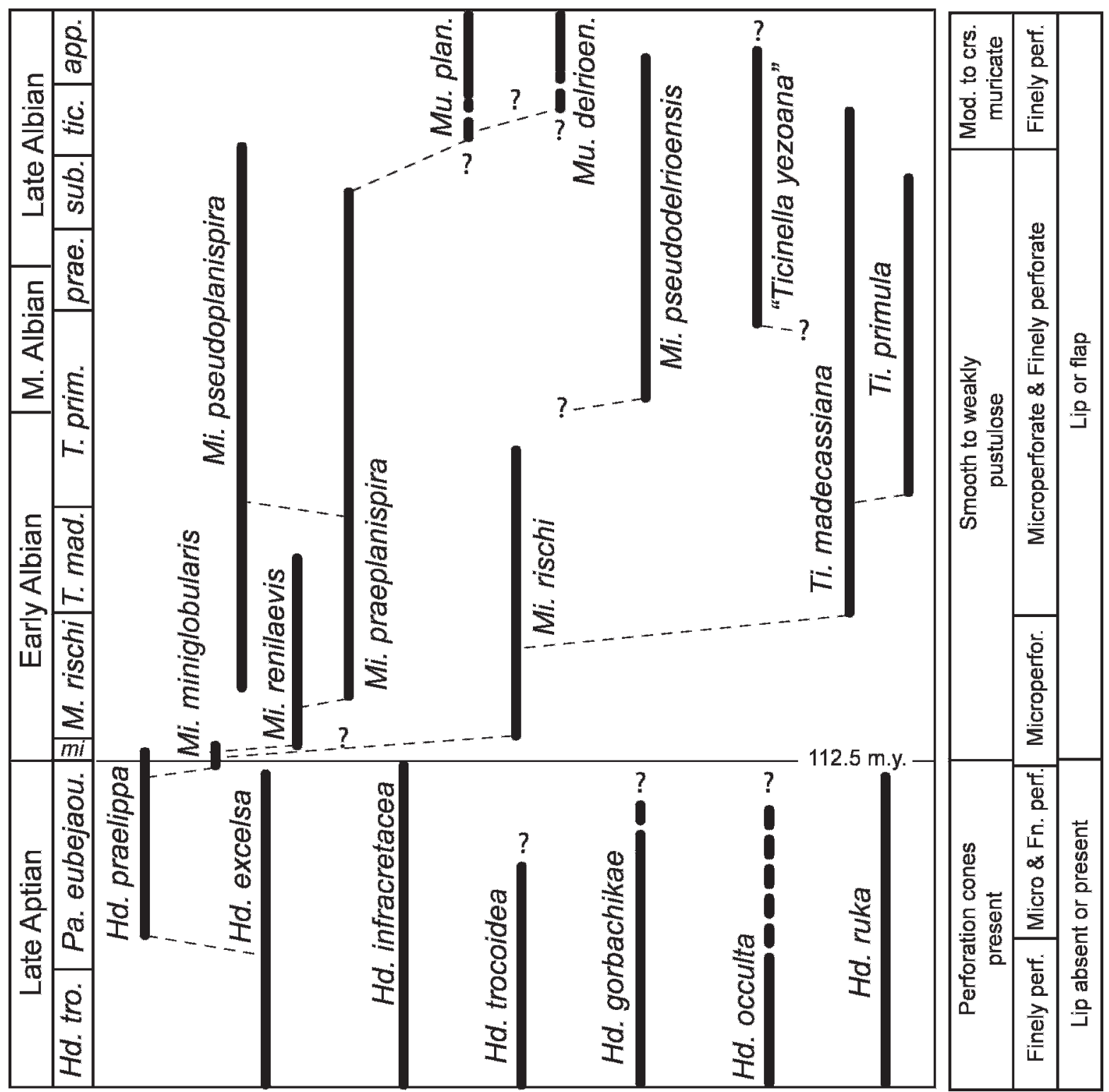

FIGURE 13. Stratigraphic ranges and phylogenetic relationships inferred for late Aptian-Albian species of Hedbergella, Microhedbergella, Macrohedbergella, and Ticinella. Right side of diagram represents evolutionary (stratigraphic) changes in, from left to right, wall surface texture, wall pore size category, and peri-apertural features for the hedbergellid plexus.

distributed and variably spaced in adult chambers, surface smooth or with scattered and weakly developed pustules, very rarely observed with small, scattered perforation cones. Test small to moderate in size, coiled in a very low to low trochospire, spiral side evolute, umbilical side mostly involute; chambers globular, never elongated radially, increasing rapidly to moderately in size, with 3-6 in the final whorl; aperture a low interiomarginal, umbilical-extraumbilical arch bordered by a thin lip or flap that may extend partly into umbilical region.

Remarks. Microhedbergella differs from Hedbergella primarily by its generally smaller size, particularly in the early species, by having a thinner shell wall $(<3 \mu \mathrm{m}$ vs. 4 $6 \mu \mathrm{m}$; Figs. 4a, 4b) that is microperforate with a smooth surface, and by always having an apertural lip or flap.
Microhedbergella resembles Praehedbergella because of its small test size, relatively thin wall and smooth wall texture, but these genera are considered as distantly related homeomorphic lineages because of the stratigraphic gap that separates species included within each of the genera. The new genus is here defined in order to avoid the recognition of polyphyletic morphotaxa.

Species included. Microhedbergella miniglobularis n. sp., Mi. praeplanispira n. sp., Mi. pseudoplanispira n. sp., Mi. pseudodelrioensis, Mi. renilaevis n. sp., and Mi. rischi (Moullade).

Etymology. The prefix micro- is added to the pre-existing genus name Hedbergella in reference to the microperforate wall microstructure.

Stratigraphic range. Uppermost Aptian-upper Albian.

Geographic distribution. Cosmopolitan. 


\section{$511-55-5,27-55 \mathrm{~cm}$}

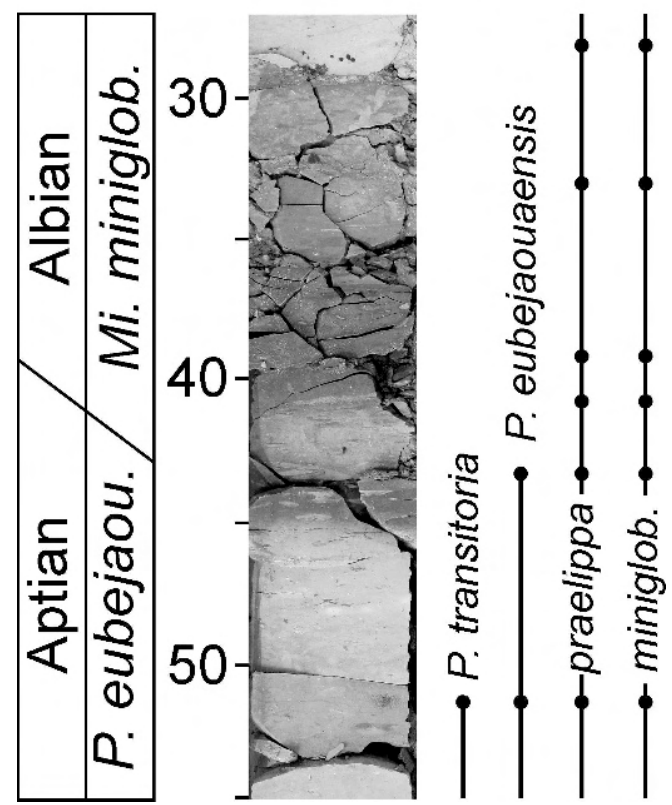

FIgURE 14. Closeup photo of changes in lithology across the AABI of DSDP Site 511 Core $511-55-5,27-55 \mathrm{~cm}$. Note that the extinction of the two Aptian species of Paraticinella does not occur at major a lithologic break, suggesting that this biotic transition occurs across an interval of continuous sedimentation.

Microhedbergella miniglobularis Huber and Leckie, n. sp. Figs. 12.6-12.8, 15.1, 15.2

"Hedbergella sp., 3 chambers", Caron in Kennedy and others, 2000, fig. 22c.

Description. Test wall microperforate, pore diameter ranging $0.4-0.8 \mu \mathrm{m}$, surface smooth or with very fine pustules. Test very small, coiled in a low to rarely moderate trochospire, equatorial periphery moderately to strongly lobate, unequally biconvex, test thickness:diameter ratio averaging 0.61 ; chambers inflated, dextrally or sinistrally coiled in 1.5-2 whorls of 6-8 chambers that increase rapidly in size with 3-4 chambers in the final whorl, ultimate:penultimate ratio averaging 1.1 , final chamber slightly reniform; sutures depressed, radial, straight; umbilicus shallow, narrow; aperture an extra-umbilical low arch that extends from near the peripheral margin nearly to the umbilicus, bordered by a narrow lip. Holotype: maximum diameter $95 \mu \mathrm{m}$, thickness $66 \mu \mathrm{m}$, proloculus $30 \mu \mathrm{m}$. Paratypes and hypotypes: diameter ranging 76-95 $\mu \mathrm{m}$ and averaging $87 \mu \mathrm{m}$, proloculus ranging $20-30 \mu \mathrm{m}$ and averaging $24 \mu \mathrm{m}$.

Remarks. Microhedbergella miniglobularis most closely resembles Hedbergella praelippa n. sp., but differs by having more inflated chambers, a more lobate equatorial periphery, a more rapid chamber size increase, presence of a lip bordering the aperture, and absence of perforation cones. Microhedbergella miniglobularis differs from early forms of $M i$. renilaevis by its narrow umbilicus and distinctly more globular chambers. Although its small size suggests it may represent a juvenile morphology of a larger form, the Site 511 samples contain exclusively small sized planktic foraminifer tests (Fig. 9) together with larger-size benthic foraminifera and other biogenic constituents.
Caron (in Kennedy and others, 2000, fig. 22b) illustrated transmitted light photomicrographs and recorded occurrences of "Hedbergella sp., 3 chambered" that first occur just above the extinction of Paraticinella eubejouaensis in the Pré-Guittard section of the Vocontian Basin. Comparison of SEMs of the 3-chambered specimens, provided courtesy of M. Caron, with specimens from Site 511 (e.g., Figs. 12.7, 12.8) shows their similarity.

Etymology. Named for the small test size and globular shell morphology.

Phylogenetic relationships. Descended from $H d$. praelippa; probable ancestor of Mi. renilaevis $\mathrm{n}$. $\mathrm{sp}$.

Stratigraphic range. From near the top of the Paraticinella eubejaouaensis Zone (uppermost Aptian) through lowermost $\mathrm{Mi}$. rischi Zone (lowermost Albian).

Geographic distribution. Identified at DSDP Site 511 (southern South Atlantic), ODP Site 1049 (western subtropical North Atlantic), ODP Site 763 (southeast Indian Ocean), and the Pré-Guittard Section in the Vocontian Basin of southeastern France (e.g., Fig. 12.8).

Repository. Holotype (USNM 540921) and paratypes (USNM 540922, 540923) deposited at the Smithsonian Museum of Natural History, Washington, D.C.

\section{Microhedbergella praeplanispira Huber and Leckie, n. sp.} Figs. 16.1-16.7

Description. Test wall microperforate $(0.8-1.2 \mu \mathrm{m})$, pores randomly scattered, surface smooth to weakly pustulose, very rarely observed with scattered perforation cones. Test small, low trochospiral, spiral side flat to slightly depressed, equatorial periphery rounded, moderately lobate in equatorial outline, test thickness:diameter ratio averaging 0.49 ; chambers globular, increasing gradually in size, ultimate: penultimate chamber ratio averaging 1.12, dextrally or sinistrally coiled in 2.5 whorls with $5.5-7$ chambers in the final whorl; sutures moderately depressed, radial on umbilical and spiral sides; umbilicus shallow, comprising $21-26 \%$ of the test diameter; aperture an extraumbilical low arch that extends from near the equatorial peripheral margin nearly to the umbilicus, bordered by a narrow lip that usually broadens to an imperforate apertural flap extending toward the umbilicus, often with relict apertural flaps surrounding the umbilicus. Holotype: maximum diameter $205 \mu \mathrm{m}$, thickness $116 \mu \mathrm{m}$, proloculus $15 \mu \mathrm{m}$. Measured hypotypes: diameter ranging 172-240 $\mu \mathrm{m}$ and averaging $211 \mu \mathrm{m}$, proloculus ranging 15-23 $\mu \mathrm{m}$ and averaging $19 \mu \mathrm{m}$.

Remarks. The tiny hedbergellids found in the lower Albian have historically been identified as Hedbergella planispira because of the similarity of low trochospiral coiling, circular test outline, 6-6.5 chambers in the final whorl, and absence of distinctive shell features that can be used to distinguish separate species. In fact, the $H d$. planispira Interval Zone was erected to characterize what was considered to be the dominate species of the early Albian. However, study of well preserved early Albian hedbergellids from DSDP Site 511 and ODP Site 1049 reveals enough differences in shell size, wall pore diameter, and wall surface texture to warrant separation of $\mathrm{Mi}$. praeplanispira from Muricohedbergella planispira. At Sites 511, where Mi. praeplanispira is most abundant, we observe 


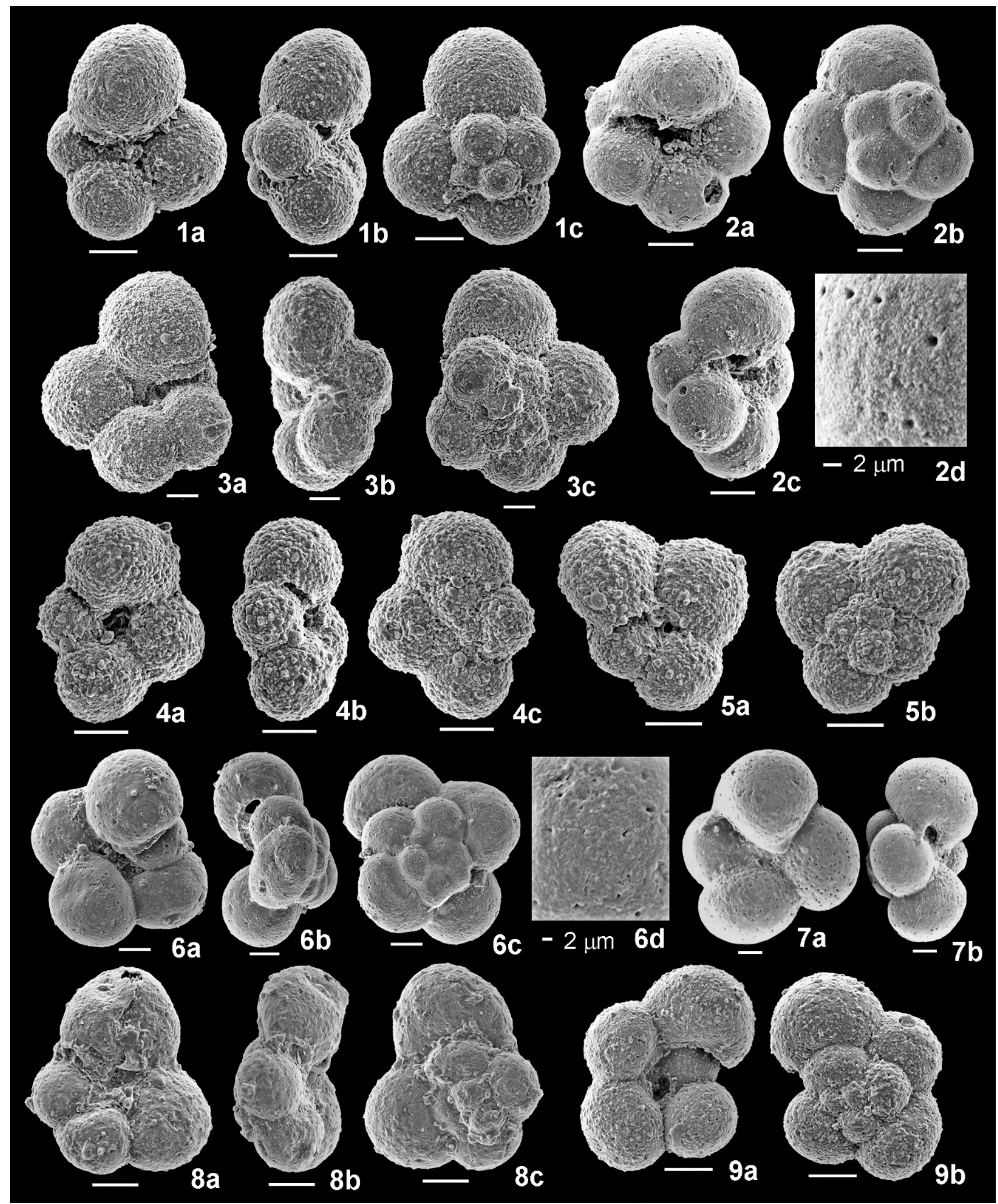

FigURE 15. Microhedbergella miniglobularis, n. sp., Mi. trans. renilaevis, and Mi. renilaevis, n. sp. from the Aptian/Albian boundary interval. Scale bars are $20 \mu \mathrm{m}$ unless shown otherwise. 1, 2 Mi. miniglobularis: 1, holotype USNM 540921, 511-55-5, 99-100 cm; 2, paratype USNM 540923, 511-55-5, 39-40 cm, showing smooth, microperforate surface of spiral side of penultimate chamber. 3-7, 9 Mi. renilaevis (trans.): 3, 511-55-1, 130$131 \mathrm{~cm} ; 4,5,511-55-5,39-40 \mathrm{~cm} ; 6,511-55-5,51-53 \mathrm{~cm}$, showing smooth, microperforate surface of umbilical side of penultimate chamber; 7, 511-542, 20-22 cm; 9, 511-55-5, 41-42 cm. 8 Mi. renilaevis, Pré-Guittard PG-12a. 


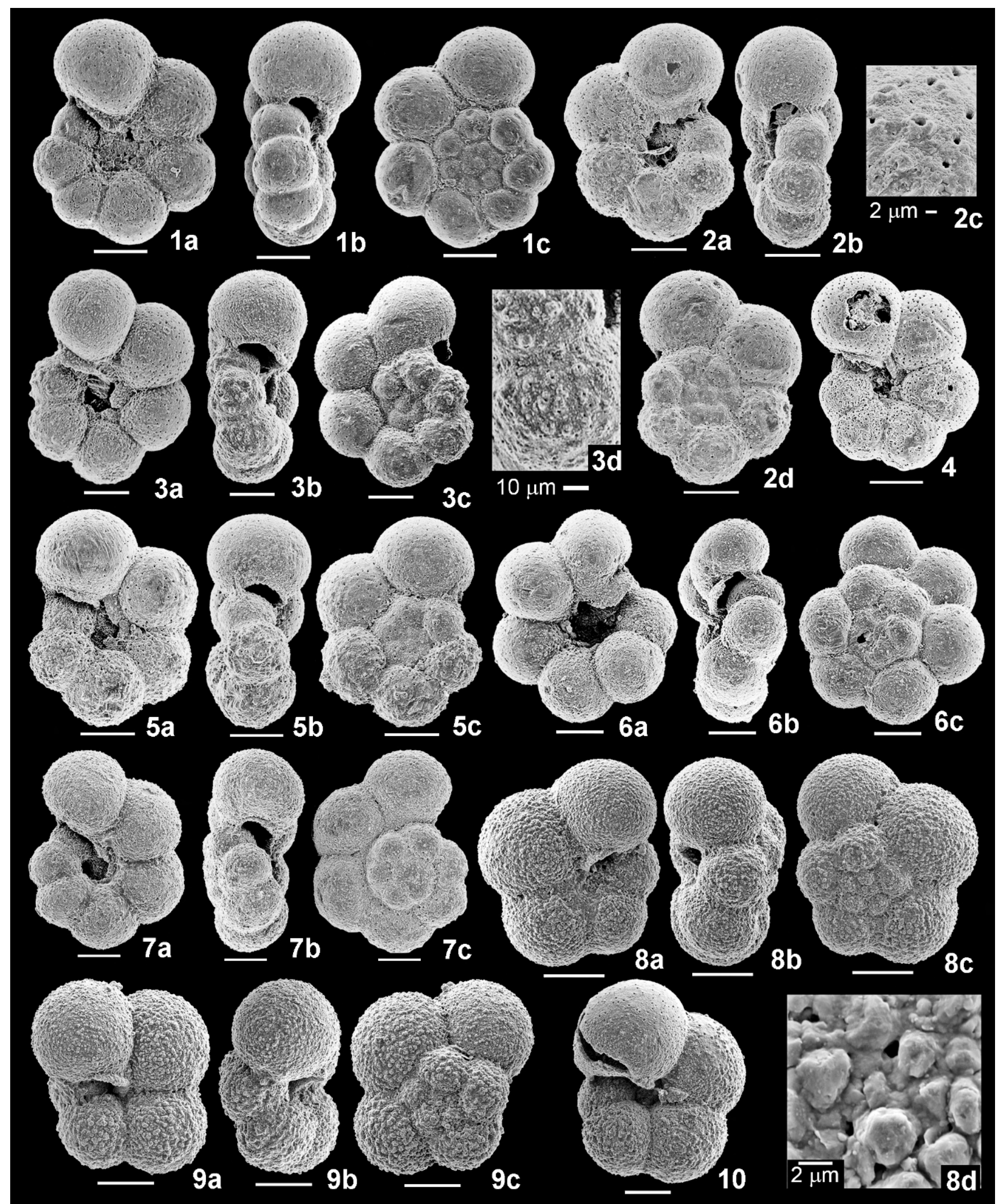

Figure 16. Early Albian Microhedbergella praeplanispira, n. sp. and Mi. pseudodelrioensis, n. sp. Scale bars $=50 \mu \mathrm{m}$ unless shown otherwise. 1-7 Mi. praeplanispira: 1, holotype USNM 540924, 511-52-6, 27-29 cm; 2, paratype USNM 540925, 511-51-6, 24-26 cm, including magnified microperforate wall on umbilical side of antepenultimate chamber showing weakly developed perforation cones; 3, 511-51-6, 24-26 cm, including magnified microperforate wall on edge of fourth to last chamber showing weakly developed perforation cones; 4, 763B-36X-3, 45.5-47.5 cm; 5, 511 51-6, 24-26 cm; 6, paratype USNM 540926, 511-52-4, 70-72 cm; 7, 1049C-11X-4, 47.5-49.5 cm. 8-10 Mi. pseudodelrioensis: 8, holotype USNM $540927,511-50-3,26-28 \mathrm{~cm}$, including magnified view of microperforate wall on umbilical side of penultimate chamber showing finely pustulose surface texture; 9, paratype USNM 540928, 511-50-3, 26-28 cm; 10, paratype USNM 540929, 511-50-3, 26-28 cm. 
an increase in maximum shell size and pore diameter from an average of 170 and $0.8 \mu \mathrm{m}$, respectively, in the lower Albian to an average of 211 and $1.1 \mu \mathrm{m}$, respectively, in the middle Albian. Pustules on the wall surface also coarsen from the base to top of its stratigraphic range.

This species is very similar to $M u$. planispira but is distinguished by its smaller size, presence of microperforate rather than finely perforate pores and smooth rather than moderately pustulose wall surface. It is distinguished from Mi. pseudoplanispira $\mathrm{n}$. sp. by its more lobate peripheral outline, more globular chambers, thicker test, and more highly arched aperture that extends more toward the umbilicus. Microhedbergella praeplanispira is distinguished from Mi. rischi by its more globular (spherical) chambers, more lobate outline, wider umbilicus, flatter spiral side, and greater development of relict apertural flaps in the umbilicus.

Etymology. Named for its existence prior to the evolutionary first occurrence of $\mathrm{Mu}$. planispira.

Phylogenetic relationships. Probably descended from Mi. rischi; may be ancestral to Muricohedbergella planispira (Fig. 13), but this morphologic transition has not been recorded.

Stratigraphic range. From lower Mi. rischi Zone (lower Albian) through Ticinella primula Zone (upper Albian). It is abundant and consistently present through nearly $50 \mathrm{~m}$ of section at Site 511; it is relatively common at Site 763, and it is relatively rare and sporadic in its occurrence at Site 1049 (Tables 1, 2, 4).

Geographic distribution. Identified at DSDP Site 511 (southern South Atlantic), ODP Site 1049 (subtropical western North Atlantic), and ODP Site 763 (southeast Indian Ocean).

Repository. Holotype (USNM 540924) and paratypes (USNM 540925, 540926) deposited at the Smithsonian Museum of Natural History, Washington, D.C.

Microhedbergella pseudodelrioensis Huber and Leckie, n. sp. Figs. 16.8-16.10

Description. Test wall microperforate, pores randomly scattered, wall surface finely pustulose. Test moderate in size, low trochospiral, equatorial periphery rounded, equatorial outline weakly lobate, test thickness:diameter ratio averaging 0.56 ; chambers globular, increasing moderately in size, ultimate:penultimate chamber ratio averaging 1.0 , antepenultimate:ultimate chamber ratio averaging 1.16, relatively tightly coiled dextrally or sinistrally in 2 whorls with 11-12 chambers in adult specimens, $4.5-5$ chambers in the final whorl; sutures moderately depressed, radial on umbilical and spiral sides; umbilicus narrow, comprising $11-16 \%$ of the test diameter; aperture a low arch that extends from the umbilicus half- to three-quarters of the distance toward the peripheral margin, bordered by a narrow lip that thickens toward the umbilicus. Holotype: maximum diameter $189 \mu \mathrm{m}$, thickness $100 \mu \mathrm{m}$, proloculus indistinct. Measured hypotypes: diameter ranging 185$230 \mu \mathrm{m}$ and averaging $204 \mu \mathrm{m}$.

Remarks. This species is distinguished from other microhedbergellids by its relatively tight coiling, giving it a moderately high test thickness:diameter ratio, presence of 4-4.5 chambers in the final whorl, faster chamber growth rate, and distinct lip that thickens toward the umbilicus. It differs from Muricohedbergella delrioensis (Carsey, 1926) by having a microperforate rather than finely or macroperforate wall and a more finely pustulose wall texture.

Etymology. Named for its resemblance to $\mathrm{Mu}$. delrioensis (Carsey, 1926).

Phylogenetic relationships. Uncertain.

Stratigraphic range. Microhedbergella rischi Zone (lower Albian) through Ticinella primula Zone (upper Albian).

Geographic distribution. Identified at DSDP Site 511 (southern South Atlantic), ODP Site 1049 (subtropical western North Atlantic), and ODP Site 763 (southeast Indian Ocean).

Repository. Holotype (USNM 540927) and paratypes (USNM 540928, 540929) deposited at the Smithsonian Museum of Natural History, Washington, D.C.

Microhedbergella pseudoplanispira Huber and Leckie, n. sp. Figs. 17.1-17.4

Hedbergella planispira Tappan, Gradstein, 1978, pl. 11, figs. 14, 15 [middle Albian, Ticinella primula Zone, DSDP Hole 392A, Blake Plateau, western North Atlantic].

Hedbergella planispira Tappan, Caron, 1978, pl. 7, figs. 7, 8 [lower Albian, DSDP Site 364, Angola Basin, eastern South Atlantic].

Description. Test wall microperforate, pores randomly scattered and averaging $0.9 \mu \mathrm{m}$ in diameter, wall surface smooth. Test small, very low trochospiral, equatorial periphery rounded, weakly lobate in equatorial outline; chambers subglobular, increasing slowly in size, ultimate: penultimate chamber ratio averaging 1.05 , dextrally or sinistrally coiled in 2 whorls with 6.5-7 chambers in the final whorl; sutures moderately depressed in last several chambers, weakly depressed to flush on earlier chambers, radial on umbilical and spiral sides; umbilicus shallow, comprising $26-30 \%$ of the test diameter; aperture an extraumbilical low arch that extends from near the equatorial peripheral margin nearly to the umbilicus, bordered by a narrow lip, with relict apertural lips surrounding the umbilicus. Holotype: maximum diameter $146 \mu \mathrm{m}$, thickness $62 \mu \mathrm{m}$, proloculus indistinct. Measured hypotypes: diameter ranging 123-212 $\mu \mathrm{m}$ and averaging $152 \mu \mathrm{m}$.

Remarks. This species is distinguished from Mi. praeplanispira and $M i$. rischi by its smaller size, slower rate of chamber size increase, presence of 6.5-7 rather than 5.5-6 chambers in the final whorl, less lobate equatorial periphery, and flush sutures on the initial whorl chambers. It is common and most consistently present through nearly $50 \mathrm{~m}$ of the lower through middle Albian sequence at Site 511 , but it occurs in low abundance at sporadic intervals at Site 1049 and Hole 763B.

Etymology. Named for its resemblance to Muricohedbergella planispira.

Phylogenetic relationships. Probably descended from $M i$. praeplanispira.

Stratigraphic range. From lower $\mathrm{Mi}$. rischi Zone (lower Albian) through Ticinella primula Zone (upper Albian). At Site $511 \mathrm{Mi}$. pseudoplanispira has its LO $\sim 2.6 \mathrm{~m}$ above the LO of Mi. praeplanispira.

Geographic distribution. Identified at DSDP Site 511 (southern South Atlantic), ODP Site 1049 (subtropical 


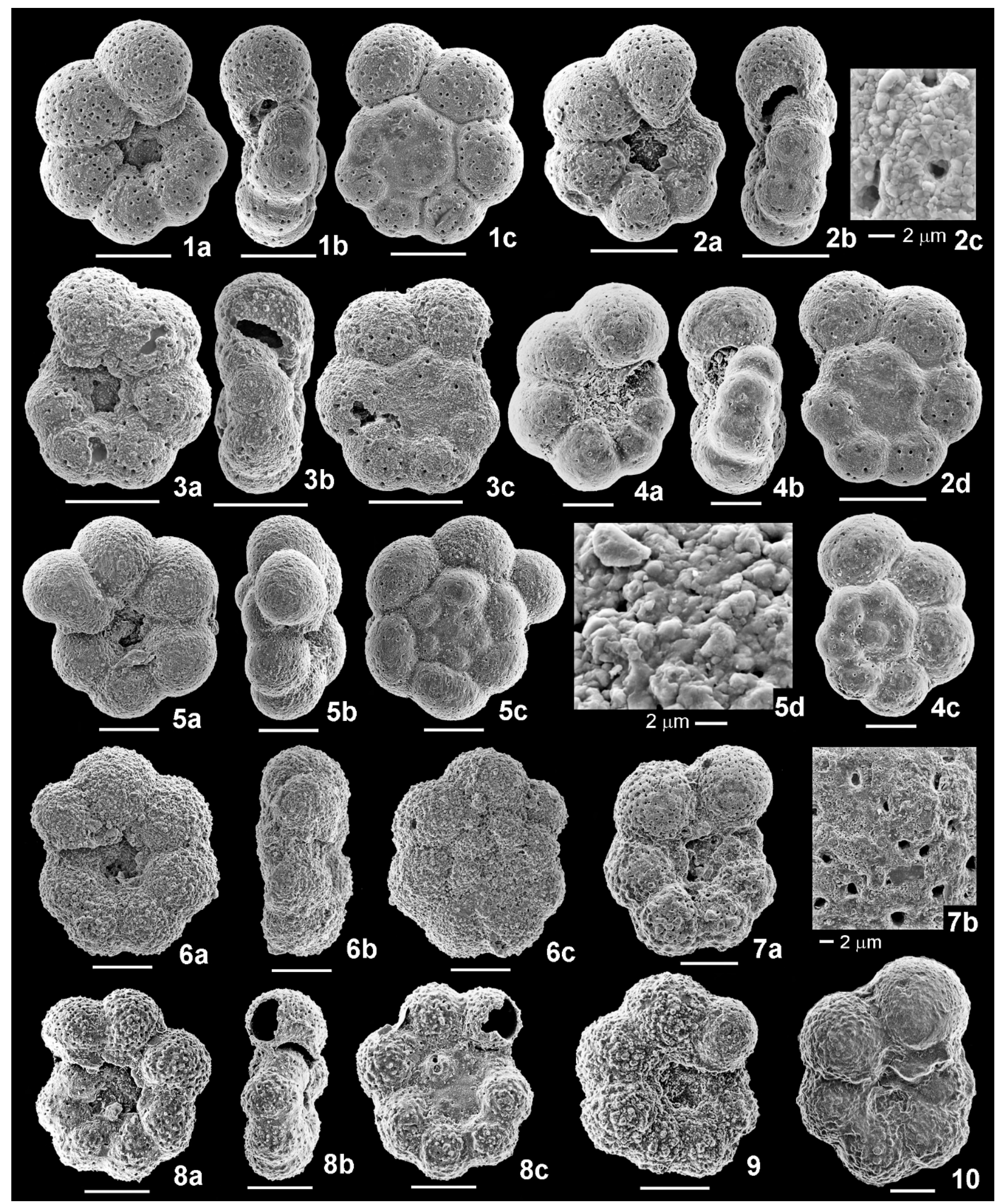

FIGURE 17. Early Albian Microhedbergella pseudoplanispira n.sp. and late Albian Muricohedbergella planispira. Scale bars $=20 \mu \mathrm{m}$ unless shown otherwise. 1-4 Mi. pseudoplanispira: 1, holotype USNM 540930, 1049C-11X-2, 124-126 cm; 2, paratype USNM 540931, 1049C-11X-2, 124-126 cm, including magnified view of smooth, microperforate wall of umbilical side of penultimate chamber; 3, paratype USNM 540932, 1049C-11X-2, 124 $126 \mathrm{~cm} ; 4$, 763B-36X-3, 45.5-47.5 cm; 5, 6, Microhedbergella trans. Mu. planispira: 5, 511-50-2, 29-33 cm, including magnified view of finely pustulose, microperforate wall texture on umbilical side of antepenultimate chamber; 6, 511-50-1, 29-32 cm. 7-10 Mu. planispira: 7, 1052E-41R-5, 99$100 \mathrm{~cm}$, including magnified view of pustulose, finely perforate wall texture on umbilical side of penultimate chamber; 8, 1052E-44R-6, 50-53 cm; 9 , 1050C-27R-1, 73-76 cm; 10, holotype USNM 219446. 
western North Atlantic), and ODP Site 763 (southeast Indian Ocean).

Repository. Holotype (USNM 540930) and paratypes (USNM 540931, 540932) deposited at the Smithsonian Museum of Natural History, Washington, D.C.

Microhedbergella renilaevis Huber and Leckie, n. sp. Figs. 15.8, 18.1-18.12

"Hedbergella sp., 4 chambers", Caron in Kennedy and others, 2000, fig. 22c.

Hedbergella speetonensis Banner and Desai tunisiensis BouDagherFadel; Erbacher and others, 2001, p. 326 [lower Albian, Blake Nose, ODP Core 1049C-12X].

Description. Test wall microperforate with randomly scattered pores averaging $0.8 \mu \mathrm{m}$ in diameter, surface smooth. Test small, low to rarely moderately low trochospiral, equatorial periphery subrounded, moderately to strongly lobate; weakly biconvex; chambers subglobular, usually reniform in equatorial view and a slightly compressed oval shape in edge view, dextrally or sinistrally coiled in two whorls of from 8-11 chambers that increase moderately in size, usually with 4 , rarely 3 and up to 5.5 chambers in the final whorl; sutures depressed, radial, straight; umbilicus shallow, moderately wide, averaging $24 \%$ of the test diameter; aperture an extraumbilical low arch that extends from the equatorial peripheral margin almost to the umbilicus, bordered by a narrow lip that usually broadens to an imperforate portical flap that may partly cover the umbilicus, with relict portici surrounding the umbilicus. Holotype: maximum diameter $135 \mu \mathrm{m}$, thickness $63 \mu \mathrm{m}$, proloculus $16 \mu \mathrm{m}$. Measured hypotypes: diameter ranging $72-180 \mu \mathrm{m}$ and averaging $130 \mu \mathrm{m}$, proloculus ranging $11-22 \mu \mathrm{m}$ and averaging $17 \mu \mathrm{m}$.

Remarks. Microhedbergella renilaevis n. sp. is distinguished from other species of Microhedbergella by having a more-compressed test, a wider umbilicus, chambers that are more reniform or lobate in equatorial view, and common presence of an apertural flap and portici. Its test wall is always microperforate, and the wall surface on wellpreserved specimens is very smooth and never has perforation cones (Figs. 18.1d, 18.3d). It shows high morphologic variability regarding total and final whorl chamber number, chamber lobateness, tightness of coiling, chamber growth rate, width of umbilicus, and height of the coiling axis. The earliest transitional forms tend to have a higher spire (e.g., Figs. 15.3-15.9). These and slightly younger forms all have a narrow lip surrounding the aperture without a portical flap or portici, which occur on more highly evolved forms (e.g., Figs. 18.1a, 18.3a, 18.6a, 18.10a).

In her foraminiferal study of the Aptian/Albian boundary in the Pré-Guittard section of the Vocontian Basin, Caron (in Kennedy and others, 2000, fig. 22c) illustrated transmitted-light photomicrographs and recorded occurrences of specimens referred to as "Hedbergella sp., 4 chambered", which are here considered as early forms of Mi. renilaevis based on similarity in size and morphology. Comparison of micrographs from the same samples used in the Kennedy and others (2000) study (provided courtesy of M. Caron, 2009), from just above the extinction of Paraticinella eubejouaensis, with specimens from Site 511 (e.g., Figs. 15.8, 18.9) reveal their strong resemblance.
Etymology. Named from renis (Latin) meaning kidneyshaped, and laevis (Latin) meaning smooth.

Phylogenetic relationships. Probably descended from $M i$. miniglobularis.

Stratigraphic range: It is very common in the lower Albian of Blake Plateau, ranging from immediately above the extinction of $\mathrm{Pa}$. eubejaouaensis (=Aptian/Albian boundary) Sample 1049C-12X-4, 145-147 cm through $-11 \mathrm{X}-2,124-126 \mathrm{~cm}$. It also occurs in low abundance at Falkland Plateau, ranging from Sample 511-55-4, 60-61 cm through -51-5, 24-26 cm and at Site 763 (Exmouth Plateau), ranging from the lower through middle Albian (Mi. rischi Zone through $\mathrm{Ti}$. madecassiana Zone). In the Vocontian Basin Col de Pré-Guittard section (see Kennedy and others, 2000) ranges from Sample PG-12a through -18.

Geographic distribution: Identified at Blake Plateau (North Atlantic, Sites 390, 1049), Falkland Plateau (southern South Atlantic, Site 511), Exmouth Plateau (southeastern Indian Ocean, Hole 763B) and western Tethys (Vocontian Basin, southeast France).

Stable isotope paleobiology: A mixed layer dweller that is consistently more positive in $\delta^{18} \mathrm{O}$ than co-occurring $\mathrm{Mi}$. rischi by an average of $0.24 \%$ and more negative in $\delta^{13} \mathrm{C}$ than co-occurring $\mathrm{Mi}$. rischi by an average of $0.16 \%$ (Fig. 19).

Repository. Holotype USNM 540933 and paratypes USNM 540934 and USNM 540935) deposited at the Smithsonian Museum of Natural History, Washington, D.C.

Microhedbergella rischi (Moullade, 1974)

Figs. 20.1-20.6, 21.1

Hedbergella (Hedbergella) sp. aff. infracretacea (Glaessner), Moullade, 1966 , p. 89, 90, pl. 8, figs. 6-16.

Hedbergella (Hedbergella) aff. infracretacea (Glaessner), Risch, 1969, p. 102, pl. 8, figs. 4-6.

Hedbergella rischi Moullade, 1974, p. 1816

Hedbergella rischi Moullade, Bellier and Moullade, 2002, p. 16-18, pl. 1, figs. 1-6 [lower Albian, Blake Nose, Sample 1049A-19X-CC].

Hedbergella aff. H. trocoidea, Erbacher and others, 2001, p. 326 [lower Albian, Blake Nose, ODP Core 1049C-12X].

Praehedbergella $\mathrm{cf}$. infracretacea infracretacea (Glaessner), Moullade and others, 2002, figs. 6H-K [lower Albian, Blake Nose, Sample 1049A-19X-CC].

Emended description. Test wall microperforate in older part of its evolutionary range (pore diameters $0.7-1.0 \mu \mathrm{m}$ ), finely perforate in its younger range (pore diameter 1.0 $2.0 \mu \mathrm{m}$ ), with widely scattered and randomly distributed pores, wall surface smooth. Test small, coiled in a low to moderate trochospire, equatorial periphery rounded, weakly to moderately lobate in equatorial view; chambers subglobular to globular, increasing moderately in size, 1113 coiled in 2-2.5 whorls with 4.75-6, rarely 6.5 in the final whorl, never with kummerform chambers, penultimate:antepenultimate chamber length ratio averaging 1.3 , sutures moderately depressed, radial on umbilical side, radial to slightly oblique on spiral side; umbilicus moderately deep and narrow, comprising 16-26\% of test diameter; aperture an extraumbilical low arch that extends from near equatorial peripheral margin nearly to the umbilicus, bordered by a narrow lip that may broaden to a flap in final chamber, with weakly developed relict apertural lips 


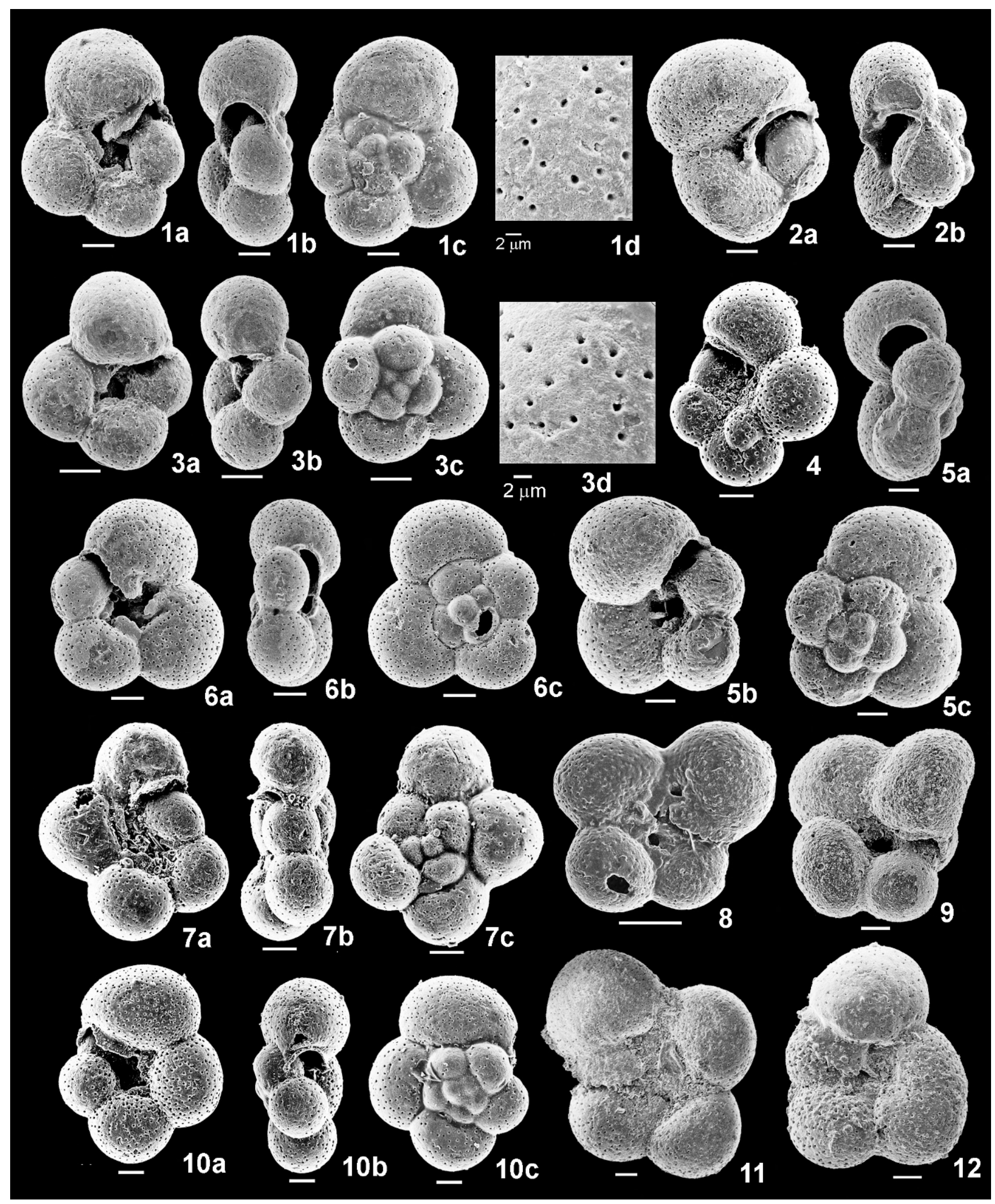

FIgURE 18. Microhedbergella renilaevis, n. sp. from the early Albian Mi. rischi Zone. Scale bars are 20 um unless shown otherwise. 1 Holotype USNM 540933, 1049C-12X-3, 39-41 cm, including smooth, microperforate umbilical side of penultimate chamber. 2 1049C-12X-3, 39-41 cm. 3 Paratype USNM 540934, 1049C-12X-3, 39-41 cm, including magnified view of smooth, microperforate umbilical side of penultimate chamber. 4 1049C-12X-3, 84-86 cm. 5 1049C-12X-3, 39-41 cm. 6 Paratype USNM 540935, 1049C-12X-3, 39-41 cm. 7 1049C-12X-3, 84-86 cm. 8 1049C-12X-4, $145-147$ cm. 9 511-55-1, 24-26 cm. 10 1049C-12X-3, 84-86 cm. 11 763B-37R-1, 23-25 cm. 12 763B-36R-CC, $23-25 \mathrm{~cm}$. 


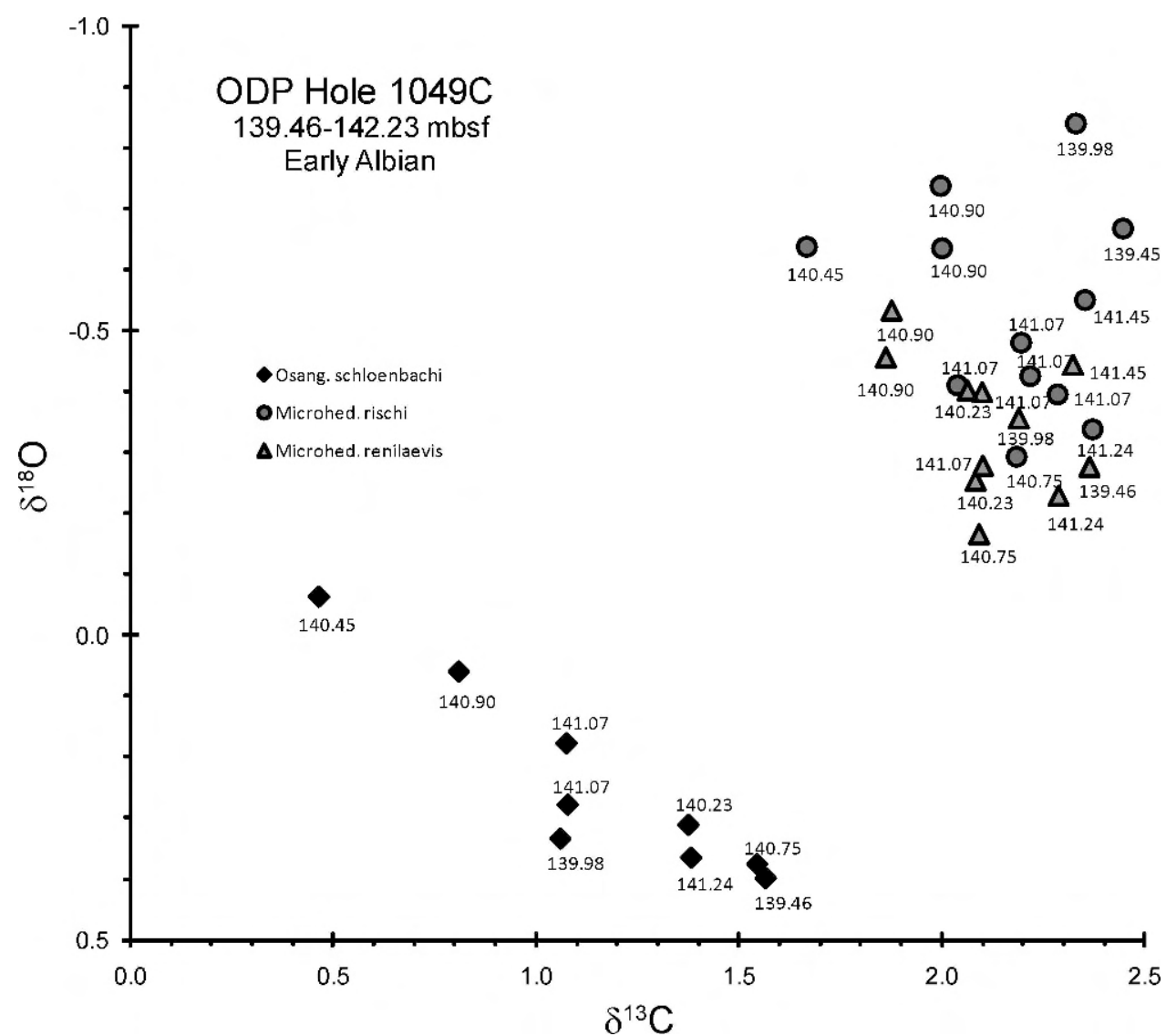

FIGURE 19. Oxygen and carbon isotope cross-plot of early Albian foraminifera from between 139.46 and 142.23 mbsf of ODP Hole 1049C. Benthic foraminifera are represented by diamond symbols for Osangularia schloenbachi (Reuss) while planktic foraminifera are represented by all other symbols.

surrounding the umbilicus. Test size generally ranges 120 $180 \mu \mathrm{m}$.

Remarks. Microhedbergella rischi was originally described by Moullade (1966) as Hedbergella (Hedbergella) sp. aff. infracretacea (Glaessner, 1937) and was later renamed $H d$. rischi in a short note by Moullade (1974), who designated specimens illustrated in a dissertation by Risch (1969) as the holotype and paratype. Because Risch's dissertation was not widely available, this species was poorly understood until Bellier and Moullade (2002) published illustrations of well-preserved specimens from the lower Albian of ODP Site 1049 (which they assigned to the middle Albian). Moullade and others (2002, p. 136, figs. $6 \mathrm{H}-\mathrm{K})$ considered forms identified as Praehedbergella cf. infracretacea infracretacea (Glaessner) to be directly ancestral to $M i$. rischi, although the "ancestral" forms they illustrated are from the same sample as the "descendent" $H d$. rischi specimens illustrated by Bellier and Moullade (2002, pl. 1, figs. 1-6). Both forms are here considered as variants of $M i$. rischi, as within sample populations from the middle and upper part of its range show considerable variability in tightness of coiling, umbilical width, spiral side convexity, and density and diameter of shell wall pores, (Figs. 20.1-20.3, 20.5). Hedbergella infracretacea lacks a lip and is densely covered by perforation cones. A similar morphologic variability occurs in the lower part of its range, except that all specimens are microperforate, which suggests that this species evolved from a microperforate ancestor. An evolutionary transition from Mi. miniglobularis to $M i$. rischi, with an expansion of the generating curve, increase in the total number and final whorl number of chambers, is postulated. However, forms that are intermediate between these two species have not been observed.

Moullade and others (2002) suggested that during the late Albian, Mi. rischi gave rise to Hedbergella yezoana Takayanagi and Iwamoto, 1962 (now placed in Ticinella) with an increase from $5-6$ to $7-8$ chambers in the final whorl chambers, and to Ti. primula Luterbacher by acquiring accessory sutural apertures. Given the uncertainty regarding the species concept of "Ti. yezoana" (see taxonomy), we consider its phylogenetic relationship with $\mathrm{Mi}$. rischi as unsettled (see discussion for "Ti. yezoana" below). We agree with Moullade and others that Mi. rischi and Ti. primula are phylogenetically related, but we suggest, based on stratophenetic observations, that Ti. madecassiana Sigal 1966 is an intermediate species in this evolutionary lineage (see discussion under Ti. madecassiana and Ti. primula below).

Microhedbergella rischi differs from $H d$. excelsa by the absence of perforation cones on the wall surface, presence of an apertural lip or flap, more compact coiling and generally flatter trochospire, although some higher-spired forms of Mi. rischi have been observed (e.g., Figs. 20.2, 


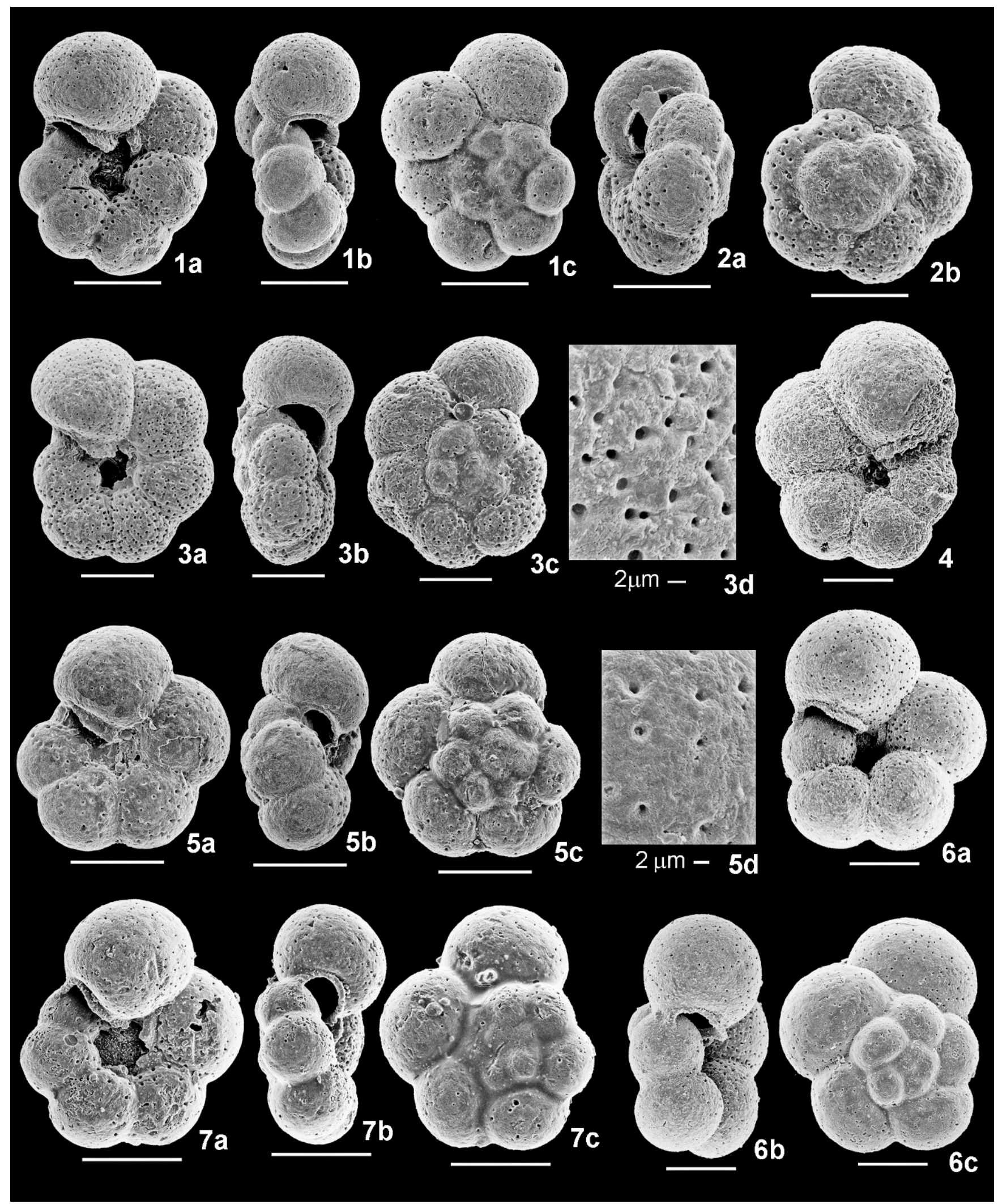

Figure 20. Early Albian Microhedbergella rischi (Moullade) from the early Albian Mi. rischi Zone. Scale bars $=20 \mu \mathrm{m}$ unless shown otherwise. 1 1049C-12X-3, 39-41 cm. 2 1049C-12X-3, 39-41 cm. 31049 C-12X-3, 39-41 cm, including magnified view of smooth, microperforate to finely perforate wall on from umbilical side of penultimate chamber. 4 763B-36X-3, 45.5-47.5 cm. 5 1049C-12X-3, 39-41 cm, including magnified view of smooth, microperforate wall on from umbilical side of antepenultimate chamber. $6511-54-1,22-24 \mathrm{~cm} .7511-54-4,124-126 \mathrm{~cm}$. 


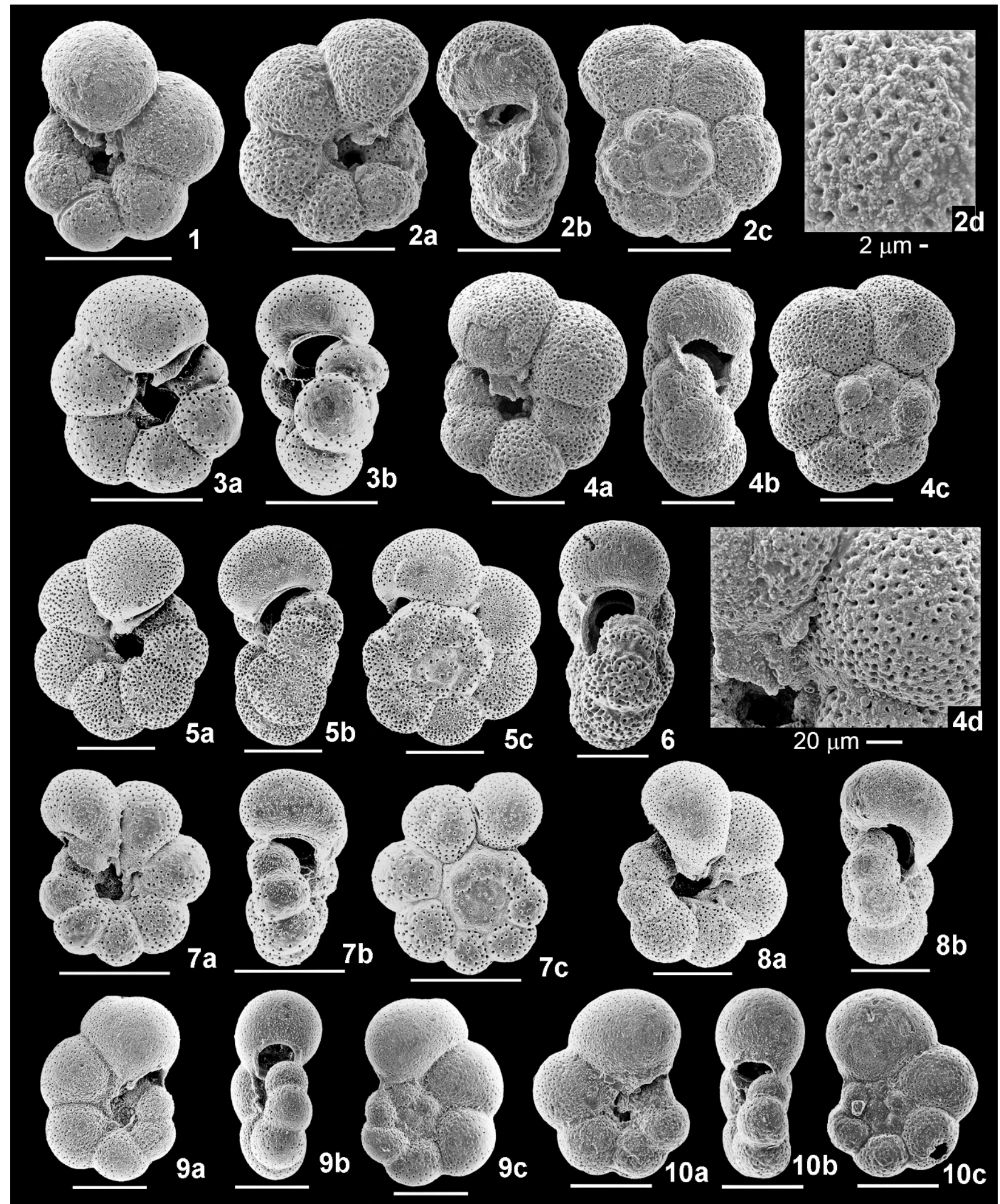

FIGURE 21. Early to middle Albian evolutionary transition from Microhedbergella rischi to Ticinella madecassiana and to Ti. primula, and "Ti. yezoana". Scale bars $=20 \mu \mathrm{m}$ unless shown otherwise. 1 Microhedbergella rischi, 1049C-11X-2, 124-126 cm. 2 Mi. rischi trans. Ti. madecassiana 1049C-11X-2, 124-126 cm, including magnified wall of umbilical side of penultimate chamber showing larger diameter of shell pores than Mi. rischi s.s. 3, 4 Ti. madecassiana: 3, 392A-2-1, $84 \mathrm{~cm}$, note weakly developed sutural accessory apertures; 4, 1049C-11X-2, 124-126 cm, with magnified umbilical view of sutural accessory aperture. 5 Ti. madecassiana trans. primula, 392A-2-1, $73 \mathrm{~cm}$. 6-8 Ti. primula: 6, 1050C-27R-1,73-76 cm; 7, 392A3-1, $94 \mathrm{~cm} ; 8,392 \mathrm{~A}-2-1,73-75 \mathrm{~cm}$. 9, 10: "Ti. yezoana": 9, 511-49-6, 24-26 cm; 10, 1050C-27R-1, 73-76 cm. 
20.5). It differs from Mi. praeplanispira by usually having more widely scattered and slightly larger pores on the shell surface, slightly less inflated and more subglobular chambers, more embracing chambers giving it a less lobate outline, more narrow umbilicus, less developed relict apertural lips in the umbilicus, and an aperture that is slightly higher and broader.

Phylogenetic relationships. Possibly descended from Mi. miniglobularis $\mathrm{n}$. sp., although no intermediate forms have been identified. Considered ancestral to Ti. madecassiana.

Stratigraphic range. It is the nominate taxon of the Mi. rischi Zone (lower Albian) through Ti. primula Zone (upper Albian). At DSDP Site 511 it ranges from $1.39 \mathrm{~m}$ above the extinction of Paraticinella eubejaouaensis to $11.03 \mathrm{~m}$ above the lowest occurrence of "Ti. yezoana".

Geographic distribution. Identified at DSDP Site 511 (southern South Atlantic), ODP Site 1049 (subtropical western North Atlantic), and ODP Site 763 (southeast Indian Ocean).

Stable isotope paleobiology. A mixed-layer dweller that is consistently more negative in $\delta^{18} \mathrm{O}$ than co-occurring $\mathrm{Mi}$. renilaevis by an average of $0.24 \%$ and more positive in $\delta^{13} \mathrm{C}$ than co-occurring Mi. renilaevis by an average of $0.16 \%$ (Fig. 19).

Genus Muricohedbergella Huber and Leckie, n. gen. Type species: Muricohedbergella delrioensis (Carsey, 1926)

Description. Test wall moderately thick, multilamellar, finely perforate, wall pores variably spaced in adult chambers, surface moderately to coarsely muricate or pustulose, never with a keel, raised sutures or imperforate peripheral margin. Test small to moderate in size, coiled in a very low to low trochospire, spiral side evolute, umbilical side mostly involute; chambers globular, never elongated radially, increasing slowly to moderately in size, with 4.5-7 in the final whorl; aperture a low interiomarginal, umbilical-extraumbilical arch that is bordered by a thick lip or flap that may extend partly into the umbilical region.

Remarks. Muricohedbergella differs from Microhedbergella primarily by its larger test size, by having a thicker, finely perforate shell wall (pores $1-2.5 \mu \mathrm{m}$; Fig. 17.7b) and by having a moderately to coarsely muricate or pustulose wall, rather than a smooth, surface texture. Petrizzo and Huber (2006) provide an emended description of $M u$. delrioensis.

Species included. Muricohedbergella angolae (Caron), Mu. astrepta (Petrizzo and Huber), Mu. crassa (Bolli), Mu. delrioensis (Carsey), Mu. flandrini (Porthault), Mu. holmdelensis (Olsson), Mu. implicata (Michael), Mu. intermedia (Michael), Mu. loetterli (Nauss), Mu. monmouthensis (Olsson), Mu. planispira (Tappan), Mu. portsdownensis (Williams-Mitchell), Mu. praelibyca (Petrizzo and Huber), and $M u$. sliteri (Huber).

Etymology. Follows usage in Premoli Silva and Verga (2004), the prefix murico- is added to the pre-existing genus name Hedbergella to denote presence of moderate to coarse pustules or muricae on the test surface.

Stratigraphic range. Upper Albian through Maastrichtian.

Geographic distribution. Cosmopolitan.
Muricohedbergella planispira (Tappan, 1940)

Figs. 17.6-17.10

Globigerina planispira Tappan, 1940, p. 12, pl. 19, fig. 12 [Cenomanian, Grayson Formation, Denton County, Texas].

Hedbergella planispira (Tappan), Robaszynski, Caron, and others, 1979 , p. 139, pl. 27, figs. 1a-c [topotype, Grayson Formation, Texas]. Haig, 1992, p. 291, pl. 5, figs. 17-18 [middle Albian, Site 766, Exmouth Plateau, southeast Indian Ocean]. Petrizzo and Huber, 2006, p. 185, pl. 7, figs. 1, 2 [upper Albian-Cenomanian, Sites 1050 1052, Blake Plateau, western North Atlantic]. Leckie, 1984, p. 599, pl. 9, figs. 6, 7 [upper Albian, Site 547, Moroccan margin, eastern North Atlantic].

Emended description. Test wall finely perforate with pores up to $2 \mu \mathrm{m}$ in diameter, surface of all but last chamber densely covered by irregularly distributed pustules, last chamber smooth. Test low trochospiral, equatorial outline circular and weakly lobate, peripheral margin rounded; chambers globular, increasing slowly in size as added, 12-15 in total, 6-7.5 in the final whorl, last chamber can be kummerform; umbilicus shallow, moderately wide, usually comprising $25-28 \%$ of the test diameter; sutures radial and depressed on both sides; primary aperture umbilical-extraumbilical, bordered by a thick, narrow lip. Maximum test diameter averages about $185 \mu \mathrm{m}$ and ranges from $150-260 \mu \mathrm{m}$.

Remarks. Muricohedbergella planispira probably evolved from Microhedbergella pseudoplanispira during the late middle to late Albian following an increase in overall test size, an increase in the wall pore diameter, and increased density and coarseness of pustules on the wall surface. However, the complete evolutionary transition between these species has not been documented at any site so far, as it is absent from lower-middle Albian sediments at Site 1049 and its presence in the oldest sediments at Sites 1050 and 1052 (Rotalipora ticinensis Zone; Petrizzo and Huber, 2006) postdates its evolution. It is distinguished from the other Muricohedbergella species by having a higher number of chambers in the last whorl that increase gradually in size.

Stratigraphic range. The lowermost range of $M u$. planispira has been documented in the upper Mi. rischi Zone of Site 763 (Exmouth Plateau), which is considerably lower than at other sites. It was identified in the upper Albian Rotalipora ticinensis Zone at the bottom of the drill holes at Sites 1050 and 1052 (Blake Plateau), it is absent from middle Albian sediments of Site 392 (Blake Plateau) that are assigned to the Ticinella primula Zone, and it was not observed in Albian sediments at Site 511 (Falkland Plateau).

Geographic distribution. Cosmopolitan.

Subfamily Paraticinellinae Huber and Leckie, n. subfam.

Description. Test trochospirally enrolled, wall finely perforate, rugose with development of short, irregular ridges that may parallel the equatorial periphery on early chambers of the outer whorl; primary aperture umbilicalextraumbilical in position without a bordering lip but labial flaps may extend over the umbilicus and fuse and small, infralaminal secondary apertures may be present.

Remarks. This subfamily is erected to include forms that have clearly evolved from the Hedbergellidae (ancestor: $H d$. trocoidea) and are, therefore, are unrelated to any taxa in the Family Rotaliporidae.

Stratigraphic range. Restricted to the late Aptian.

Geographic distribution. Cosmopolitan. 
Genus Paraticinella Premoli Silva, Caron, Leckie, Petrizzo, Soldan and Verga, 2009

Paraticinella eubejaouaensis (Randrianasolo and Anglada, 1998)

Figs. 10.4, 10.6

Ticinella bejaouaensis Sigal, 1966 in Moullade, 1966, emend., p. 103, pl. 9, figs. 4, 5 [uppermost Aptian, Djebel Bejaoua, Tunisia].

Ticinella bejaouaensis Sigal, 1966, Caron 1978, pl. 2, figs. 9, 10 [upper Aptian, DSDP Site 364, Angola Basin].

Ticinella roberti s.l. (Gandolfi), Leckie, 1984, p. 600, 601, pl. 5, figs. 510 (not figs. 1-4, 11, 12) [upper Aptian, DSDP Site 545, eastern North Atlantic].

Ticinella eubejaouaensis Randrianasolo and Anglada, 1998, p. 298.

Paraticinella eubejaouaensis Randrianasolo and Anglada, Premoli Silva and others, 2009, p. 131-135, text-fig. 3.3-3.6, pl. 2, figs. 1-6 [upper Aptian, DSDP Site 545, Mazagan Plateau, eastern North Atlantic].

Remarks. Premoli Silva and others (2009) provide a detailed redescription of $P a$. eubejaouaensis and characterize its evolutionary transition from its ancestor, Hedbergella trocoidea. These authors state that Pa. eubejaouaensis is distinguished from $H d$. trocoidea by having 1) a generally larger test size, 2) typically more numerous chambers (8-10 in Pa. eubejaouaensis and 6.5-7.5 in $\mathrm{Hd}$. trocoidea), 3) less embracing chambers, 4) a smaller final chamber, 5) a wider umbilicus that may possess umbilical flaps, and 6) welldeveloped rugosities that parallel the periphery of the early chambers of the final whorl, a feature that is lacking in $H d$. trocoidea. These authors note that secondary supplementary apertures are rarely present in this species. Paraticinella transitoria is closely related to $P a$. eubejaouaensis and may range slightly higher.

Stratigraphic range. Nominate taxon for the uppermost Aptian $\mathrm{Pa}$. eubejaouaensis Zone, and its extinction is used to approximate placement of the Aptian/Albian boundary. Geographic distribution. Cosmopolitan.

\section{Paraticinella transitoria (Longoria, 1974)}

Figs. 10.2, 10.5

Ticinella bejaouaensis Sigal transitoria Longoria, 1974, p. 94, 95, pl. 21, figs. 9-11, 14-16 [uppermost Aptian, Vocontian Basin, Drôme region, southeast France].

Ticinella bejaouaensis transitoria Longoria, Pflaumann and Krashenninikov, 1977, p. 549 [upper Aptian, DSDP Hole 369A, Cape Verde Basin, eastern South Atlantic].

Hedbergella (Ticinella) bejaouaensis Sigal, Dupeuble, 1979, pl. 2, figs. 1-3 [upper Aptian, DSDP Hole 400A, Bay of Biscay, eastern North Atlantic].

Remarks. This species is distinguished from $P a$. eubejaouaensis by having a medium to higher axis of coiling, fewer number of chambers (5.5-7 rather than 8-10) in the final whorl, and a smaller umbilicus, and by lacking apertural flaps or an umbilical cover plate. As with $\mathrm{Pa}$. eubejaouaensis, rugosities are coarser on the early chambers of the final whorl and are typically aligned parallel to the equatorial outline and supplementary apertures are rarely present. It differs from $H d$. trocoidea by the absence of a cover plate and presence of rugosities that may show parallel alignment with the equatorial outline on earlier chambers in the final whorl (e.g., Fig. 10.5d). Although Pa. transitoria appears to be morphologically transitional between $\mathrm{Hd}$. trocoidea and $\mathrm{Pa}$. eubejaouaensis, the LO of this species has only been reported above the LO of $\mathrm{Pa}$. eubejaouaensis.
Stratigraphic range. Uppermost Aptian, ranging from the middle through the top of the Pa. eubejaouaensis Zone.

Geographic distribution. Cosmopolitan.

\author{
Family Rotaliporidae Sigal, 1958 \\ Subfamily Ticinellinae Longoria, 1974 \\ Genus Ticinella Reichel, 1950 \\ Ticinella madecassiana Sigal, 1966
}

Figs. 21.3, 21.4

Ticinella madecassiana Sigal, 1966, p. 197, pl. 3, figs. 7a-10b [upper Albian, Diego-Suarez borehole, 121.2 m, Madagascar].

Ticinella madecassiana Sigal, Leckie, 1984, p. 600, pl. 6, figs. 7-12 [upper Albian, DSDP Site 545, eastern North Atlantic].

Ticinella madecassiana Sigal, Lipson-Benitah and Almogi-Labin, 2000, p. 12, pl. 1, figs. 6-8 [upper Albian, Yam S.T. borehole, offshore Israel].

Remarks. This species is characterized by having a circular to subcircular and weakly lobate equatorial outline with a rounded peripheral margin, a moderate chamber growth rate with 5-6.5 chambers in the final whorl, a narrow and deep umbilicus, at least one sutural supplementary aperture that is nearly intraumbilical in position, and a finely perforate to macroperforate wall with a nearly smooth surface, with raised rims surrounding the pores (e.g., Fig. 21.4d) or, in more evolutionarily advanced forms, interpore ridges on earlier chambers of the final whorl (e.g., Lipson-Benitah and Almogi-Labin, 2000).

The evolutionary transition from Microhedbergella rischi to Ticinella madecassiana is best documented by a stratigraphic series of lower to middle Albian samples yielding well preserved assemblages at ODP Site 1049. Transitional morphotypes, which are characterized by 1) absence of supplementary sutural apertures; 2) a larger diameter and greater density of shell pores than in $M i$. rischi; and 3) development of a "ticinellid wall texture" with raised, flattened rims that surround the pores (Fig. 21.2d). The appearance of at least one supplementary aperture on an umbilical suture (Figs. 21.3a, 21.4a) is the basis for distinguishing Ti. madecassiana s.s from the Mi. rischi trans. madecassiana ancestral forms.

The lower to middle Albian sequence at Site 1049 is truncated by a major unconformity that spans below the lowest occurrence of Ti. primula. Ticinella madecassiana differs from $T i$. primula by having a less-lobate equatorial outline, a less-broadly rounded peripheral margin, a more circular peripheral outline, fewer chambers in the final whorl, a faster rate of chamber size increase, and a narrower umbilicus. While most authors record the occurrence of forms that are intermediate in morphology between $T i$. madecassiana and Ti. primula, middle Albian samples from DSDP Site 392 (Fig. 5) provide evidence for their close phylogenetic relationship (see also Leckie, 1984).

Stratigraphic range. Upper lower Albian (Ti. madecassiana Zone) to uppermost Albian (Planomalina buxtorfi Subzone).

Geographic distribution. Cosmopolitan.

Ticinella primula Luterbacher, 1963 Figs. 21.6-21.8

Ticinella primula Luterbacher, in Renz and others, 1963, p. 1085, fig. 4 [upper Albian, western Switzerland].

Ticinella primula Luterbacher, Leckie, 1984, p. 600, pl. 6, figs. 1-6 [upper Albian, DSDP Site 545, eastern North Atlantic]. 
Ticinella primula Luterbacher, Lipson-Benitah and Almogi-Labin, 2000, p. 14, pl. 2, figs. 4-7 [middle-upper Albian, Yam boreholes, offshore Israel].

Remarks. This species is characterized by having a subcircular to elliptical and moderately lobate equatorial outline, 7-8 final whorl chambers that are broadly rounded in edge view and increase gradually in size, a finely perforate to macroperforate wall with nearly smooth surface, a broad umbilical-extraumbilical aperture that is bordered by a imperforate flap that may extend into the umbilicus, and two or more supplemental sutural apertures that are positioned near the umbilicus.

Stratigraphic range. Middle Albian (Ti. primula Zone) to uppermost Albian (Planomalina buxtorfi Subzone).

Geographic distribution. Cosmopolitan.

Stable isotope paleobiology. Considered by Petrizzo and others (2008) as a dweller of the summer mixed layer.

"Ticinella yezoana" (Takayanagi and Iwamoto, 1962) Figs. 21.9-21.10

Hedbergella trocoidea (Gandolfi) yezoana Takayanagi and Iwamoto, 1962, p. 191, 192, pl. 28, figs. 1, 2 [upper Albian, lower middle Yezo Group, Hokkaido Island, Japan].

Hedbergella yezoana Takayanagi and Iwamoto, Haig, 1992, p. 291, pl. 6, figs. 3, 4 [upper Albian, Site 766, Exmouth Plateau, southeast Indian Ocean].

Remarks. The holotype of Hd. trocoidea yezoana is quite poorly preserved as it is infilled and strongly recrystallized, such that it is not possible to observe the wall microstructure or the shape and size of the primary aperture (see SEM of yezoana at http://portal.chronos.org/gridsphere/ gridsphere?cid=res_taxondb). The test morphology of the holotype closely resembles that of $T i$. primula, as it has 7 chambers in the final whorl that increase slowly in size and the last several chambers begin to uncoil. However, the poor preservation prevents determination whether secondary sutural apertures are present. The paratype of yezoana looks quite different from the holotype as it has a faster chamber size increase and its final chamber is considerably larger than the penultimate chamber, and it does not show the tendency to uncoil. Specimens from the upper Albian of Site 511 (Figs. 21.9-21.10) are tentatively identified as "yezoana" because of their strong similarity with the yezoana paratype. They are assigned to Ticinella because of the finely perforate, smooth wall texture and presence of supplementary apertures in the umbilicus. Further study of the "yezoana" forms from other locations and comparison with topotype populations is needed to determine their correct taxonomic affinity and establish their total stratigraphic range.

Stratigraphic range. In the absence of middle through upper Albian biomarker species at Site 511, the LO of " $T i$. yezoana" is used to identify the "Ti. yezoana" Zone because of its distinctive presence in the upper $\sim 24 \mathrm{~m}$ of the $56-\mathrm{m}$ Albian sequence at Site 511 (see Biozonation section below). Its LO is just below the extinction of Mi rischi and $\sim 5.5 \mathrm{~m}$ above the LO of Mi. pseudodelrioensis (Fig. 9; Table 2). Its range at Site 511 is truncated at the top by an unconformity separating upper Albian from middle to upper Cenomanian sediments. At the type location in Hokkaido, Japan it occurs in the lower middle Yezo Group, which is assigned to the upper Albian. Specimens assigned to this taxon at Hole 1050C (Fig. 10) occur sporadically within the Rotalipora appenninica Zone.

Geographic distribution. Its occurrence in the western Pacific (Hokkaido Island, Japan), North Atlantic (Blake Nose, Site 1050C), southern South Atlantic (Falkland Plateau; Site 511), and southeastern Indian Ocean (Exmouth Plateau Site 763, 766) indicate that it has a cosmopolitan distribution, but confusion with its taxonomy may explain its limited recognition elsewhere.

\section{LATE APTIAN-MIDDLE ALBIAN BIOSTRATIGRAPHY}

\section{Planktic Foraminiferal Biozonation}

The biozonation outlined below and illustrated in Figure 23 is adapted from the scheme used by Bellier and Moullade (2002) for the upper Aptian-lower Albian of Site 1049. Modifications to their biozonation include new definitions for the base and top of the Microhedbergella rischi Zone and designation of a new Ticinella madecassiana Zone in the lower to middle Albian, immediately above the Mi. rischi Zone. A new Mi. miniglobularis Zone is proposed for global correlation of a brief interval that follows the terminal Aptian extinctions and precedes the lowest occurrence of Mi. rischi. A new "Ti. yezoana" Zone is defined for the middle-upper Albian of Site 511 (Austral) in the absence of lower-latitude biomarker species. Important bioevents and characteristic species are noted for each of the zones. Ages for the biozonation are based on Gradstein and others (2004).

\section{Globigerinelloides algerianus Taxon-range Zone}

Age. Late Aptian ( 119.0-116.0 Myr).

Author. Based defined by Moullade (1966), top by Sigal (1977).

Definition. Biostratigraphic interval comprising the total range of Gl. algerianus.

Remarks. This zone is identified at Site 545 and in the lowermost core samples at Site 1049, but it does not occur at Site 511 or Site 763. Species occurring within this zone include Globigerinelloides ferreolensis, Gl. aptiensis, Hedbergella infracretacea, $H d$. gorbachikae, Hd. occulta, and Hd. trocoidea. The LO of Pseudoplanomalina cheniourensis occurs in the upper part this zone.

\section{Hedbergella trocoidea Partial-range Zone}

Age. Late Aptian ( 116.0-114.3 Myr).

Author. Base defined by Sigal (1977), top by Moullade (1966).

Definition. Biostratigraphic interval comprising the partial range of $H d$. trocoidea from the $\mathrm{HO}$ of Globigerinelloides algerianus to the LO of Paraticinella eubejaouaensis.

Remarks. The zone includes common occurrences of $\mathrm{Gl}$. ferreolensis, Gl. aptiensis, Hedbergella occulta, Hd. trocoidea, $\mathrm{Hd}$. excelsa, Hd. gorbachikae, and $\mathrm{Hd}$. infracretacea. The HO of Pseudoplanomalina cheniourensis occurs near the top of this zone. 


\section{Paraticinella eubejaouaensis Taxon-range Zone}

Age. Late Aptian ( 114.3-112.5 Myr).

Author. Based defined by Moullade (1966), top by Moullade (1974).

Definition. Biostratigraphic interval comprising the total range of Pa. eubejaouaensis (= Ticinella bejaouaensis of previous studies).

Remarks. The evolutionary transition from ancestral forms of Hedbergella trocoidea to Pa. eubejaouaensis, characterized by an increase in chamber number, flattening of the spire height, widening of the umbilicus, and increased development of pustulose ridge ornamentation that parallels the shell periphery, has been described and illustrated by Premoli Silva and others (2009). In the absence of Pa. eubejaouaensis, the closely related species $P a$. transitoria can be used as a proxy for recognizing this zone, although $P a$. transitoria may have a higher $\mathrm{HO}$ than $\mathrm{Pa}$. bejaouaensis at some localities. Assemblages assigned to this zone can easily be distinguished from those of the overlying Microhedbergella miniglobularis Zone by the presence of species with much larger and more robust tests bearing the distinctive perforation-cone surface texture (e.g., $H d$. trocoidea, $H d$. infracretacea, $\mathrm{Hd}$. excelsa, $\mathrm{Hd}$. occulta, and $\mathrm{Hd}$. gorbachikae). Additional species in the zone include Pseudoguembelitria blakenosensis and Globigerinelloides aptiense, and, in the upper part, $H d$. praelippa.

Sigal (1977) considered Pa. eubejaouaensis as a biomarker for identifying the uppermost Aptian and extended its range across the Aptian/Albian boundary. However, most subsequent zonal schemes have limited the range of this species to the uppermost Aptian (Caron, 1985; Robaszynski and Caron, 1995; Leckie and others, 2002). In the Vocontian Basin, the disappearance of Pa. eubejaouaensis occurs $12 \mathrm{~m}$ below the Kilian black shale, $51 \mathrm{~m}$ below the Paquier black shale, and $20 \mathrm{~m}$ above the LO of the calcareous nannofossil Pr. columnata s.1. (subcircular form), which marks the NC7/ NC8 and CC7/CC8 zonal boundaries (Kennedy and others, 2000).

\section{Microhedbergella miniglobularis Interval Zone}

Age. Earliest Albian ( 112.5- 112.2 Myr).

Author. Base defined in this study, top by Moullade, 1974.

Definition. Biostratigraphic interval containing the nominate taxon from the $\mathrm{HO}$ of $\mathrm{Pa}$. eubejaouaensis to the $\mathrm{LO}$ of Mi. rischi.

Remarks. This zone replaces the lower $H d$. planispira Zone of previous studies. The base of the zone is defined at Sites 511 and 763 by the extinction of $P a$. eubejaouaensis (or $\mathrm{Pa}$. transitoria), which is accompanied, within a short stratigraphic thickness, by the extinction of several other Aptian hedbergellids, including $H d$. infracretacea, $H d$. occulta, $\mathrm{Hd}$. gorbachikae, and $\mathrm{Hd}$. excelsa, as well as $\mathrm{Gl}$. aptiensis. Species diversity is very low, with only $\mathrm{Hd}$. praelippa occurring with the nominate species, whose LO is just below the base of the zone. The maximum test size of both species is very small, generally not exceeding $100 \mu \mathrm{m}$. A gradual evolutionary transition from $H d$. praelippa to $M i$. miniglobularis and then to $M i$. renilaevis has been documented from the uppermost $P a$. eubejaouaensis Zone through the Mi. miniglobularis Zone (see taxonomy section). The presence of Mi. miniglobularis and other very small microperforate hedbergellids just above the extinction of Pa. eubejaouaensis and below the LO of Mi. rischi in the Pré-Guittard section of southeast France (Caron, in Kennedy and others, 2000) indicates the existence of the Mi. miniglobularis Zone in the Vocontian Basin.

\section{Microhedbergella rischi Partial-range Zone}

Age. Early-middle Albian ( 112.2- 110.3 Myr).

Author. Base defined by Moullade (1974), top by this study.

Definition. Biostratigraphic interval from the LO of $M i$. rischi (=Hedbergella rischi of previous studies) to the LO of Ticinella madecassiana.

Remarks. Because of uncertainty in the concept of the nominate taxon and limited awareness of the existence of this biozone, most previous AABI studies have placed Albian sediments below the LO of Ti. primula within the Hd. planispira Zone. Bellier and Moullade (2000) identified the $M i$. rischi Zone ( $=H d$. rischi in their study) in Hole 1049C at the LO of the nominate species, which they determined was $2.83 \mathrm{~m}$ above the extinction of $P a$. eubejaouaensis. They assigned the interval below the LO of $\mathrm{Mi}$. rischi to the $\mathrm{Hd}$. planispira Zone. However, our study of this same stratigraphic interval reveals that microperforate forms of $\mathrm{Mi}$. rischi are common to abundant throughout this interval, co-occurring only with $\mathrm{Mi}$. renilaevis (Table 1 ).

At Site $511 \mathrm{Mi}$. rischi is rare to few in relative abundance and is sporadic in its stratigraphic occurrence (Table 2). In the lower part of the Mi. rischi Zone, Mi. miniglobularis decreases in abundance and then becomes extinct, while $M i$. renilaevis becomes increasingly abundant. Higher up $M i$. praeplanispira and $\mathrm{Mi}$. pseudoplanispira sequentially appear within $2.61-4.87 \mathrm{~m}$ above the LO of Mi. renilaevis and $M i$. pseudodelrioensis has its LO in the upper part of the zone.

\section{Ticinella madecassiana Partial-range Zone}

Age. Middle Albian (( 110.3 to 109.0 Myr).

Author. Base defined in this study, top by Longoria and Gamper (1974).

Definition. Biostratigraphic interval from the LO of Ti. madecassiana to the LO of Ti. primula.

Remarks. Within the lower Albian Mi. rischi Zone at Site 1049 (see above) the well preserved planktic foraminiferal assemblages reveal a gradual evolutionary transition from $M i$. rischi to $T i$. madecassiana with changes from a smooth microperforate (Fig. 20) to an irregular, finely perforate wall microstructure (Figs. 21.1, 21.2) and then appearance of supplementary apertures (Fig. 21.4). Although Moullade and others (2002) proposed that Mi. rischi was directly ancestral to $T i$, primula, the latter species is not present in any Site 1049 samples that contain Ti. madecassiana. Unfortunately, an unconformity $2.22 \mathrm{~m}$ above the base of the Ti. madecassiana Zone (Figs. 3, 7) has eliminated the ensuing middle-late Albian record of ticinellid evolution. The LO of Ti. madecassiana also precedes the LO of Ti. primula at Site 763 supporting the Mi. rischi-Ti. madecassiana transition proposed here. 
At Sites 511 and 763, Mi praeplanispira and $M i$. pseudoplanispira are abundant and consistently occur throughout the middle and upper part of this zone, whereas these species occur in rare to few relative abundance at Site 1049.

\section{"Ticinella yezoana" Partial-range Zone (High Southern Latitude)}

Age. Middle-late Albian ( 105.0- 100.5 Myr).

Author. This study.

Definition. Biostratigraphic interval from the LO of " $T i$. yezoana" to the LO of Ti. primula.

Remarks. The LO of "Ti. yezoana" is used to subdivide the thick middle-upper Albian sequence at Site 511 in the absence of standard low-latitude biomarkers. It consistently occurs in relatively low abundance throughout the zone. Microhedbergella pseudodelrioensis also ranges throughout the zone, whereas several species of Microhedbergella, including $M i$. renilaevis, $M i$. praeplanispira, and $M i$. pseudoplanispira, have their $\mathrm{HO}$ within this zone (Table 2; Fig. 9). The LO of "Ti. yezoana" at Site 511 occurs in upper calcareous nannofossil Zone NC8 according to the nannofossil biostratigraphy of Bralower and others (1997).

\section{Ticinella primula Partial-range Zone}

Age. Middle Albian ( 110.9-106.4 Myr).

Author. Base by Longoria and Gamper (1974), top by Caron, in Bréhéret and others (1986).

Definition. Biostratigraphic interval from the LO of Ti. primula to the LO of Ti. praeticinensis.

Remarks. The evolutionary transition from Ti. madecassiana to Ti. primula is preserved at Exmouth Plateau Site 763, but not at the Mazagan Plateau and Blake Nose drill sites because unconformities have erased the middle-upper Albian record at Site 1049 and the middle and lower Albian record at Site 392A and 545 (Figs. 3, 24). Nonetheless, this evolutionary transition is suggested by the presence at Sites 545 and 392 of both species (Figs. 21.3, 21.7-21.8) together with intermediate morphotypes (Fig. 21.5). Although calcareous nannofossils indicate the presence of upper Albian sediments at Site 511, no specimens of Ti. primula have been found in them. The trend through the Albian of increasing maximum shell diameter and species diversity continues within this zone with the appearance of larger sized (250$300 \mu \mathrm{m})$ species that have larger pore diameters and morecoarsely ornamented shells (e.g., Ti. roberti, Biticinella subbreggiensis).

\section{Placement of the Aptian/Albian Boundary}

\section{DSDP Site 390 and ODP Site 1049}

Restudy of core samples from Sites 390 and 1049 reveals that the Aptian/Albian boundary should be placed at a sharp contact between a white calcareous chalk and an overlying gray calcareous claystone. In Hole 1049A (Fig. 6), the Aptian/Albian boundary is placed at $57.5 \mathrm{~cm}$ in Section 1049A-20X-4 (158.57.5 mbsf), and in Hole 1049C (Fig. 7; Table 1) it is positioned at $148 \mathrm{~cm}$ in Section 1049C-12X-4 (145.28 mbsf). Presence of evolutionarily advanced forms of $\mathrm{Pa}$. eubejaouaensis (showing welldeveloped ridges that parallel the peripheral margin; Premoli Silva and others, 2009) together with Pa. transitoria, Hd. trocoidea, Hd. infracretacea, and Hd. occulta, indicate that the white chalk interval is latest Aptian in age. The overlying gray claystone contains a strikingly different planktic foraminiferal assemblage that is better preserved than the Aptian assemblage, with many glassy specimens. The only planktic species found just above the Aptian/ Albian contact are $\mathrm{Mi}$. rischi and Mi. renilaevis. The abrupt decrease in abundance of Aptian species of Paraticinella, Hedbergella, and Pseudoguembelitria $2 \mathrm{~cm}$ above the white/ gray contact (Fig. 6) is most likely the result of reworking, as these taxa are absent from samples above this level and the $\delta^{13} \mathrm{C}$ values of $P a$. eubejaouaensis and $H d$. infracretacea are significantly offset relative to co-occurring specimens of Microhedbergella (Huber and others, in prep.). Noteworthy is the high proportion of benthic foraminifera ranging 32$69 \%$ (Fig. 6) across the AABI, which is unusually high for a pelagic chalk sequence. Dominance by benthic species in this interval cannot be attributed to dissolution of the planktic populations as the planktic tests are consistently well preserved throughout this interval.

The presence of $M i$. renilaevis and $M i$. rischi as much as $12 \mathrm{~mm}$ below the white/gray Aptian/Albian contact is attributed to downward displacement by bioturbation. This is based on: 1) the presence of gray lithologic clasts within the white chalk interval (see core photo in Fig. 6); 2) a stark contrast in shell preservation for specimens from the white chalk, with glassy preservation for $M i$. renilaevis and $M i$. rischi and a sugary, recrystallized appearance for Aptian hedbergellids; 3) a dramatic reduction in the relative abundance of $M i$. renilaevis and $M i$. rischi from the lowermost Albian to uppermost Aptian sample; and 4) an offset in $\delta^{13} \mathrm{C}$ values within the white chalk between $M i$. renilaevis and the measured Aptian species (Huber and others, in prep.). Because these pre-Albian occurrences are not considered allochthonous, no species range across the AABI at Site 1049.

Using the lowest occurrence of the calcareous nannofossil Praediscosphaera columnata s.s. (= "circular" Pr. columnata of Bown, in Kennedy and others, 2000), Browning and Watkins (2008) located the Aptian/Albian boundary in Hole $1049 \mathrm{C}$ at the base of the OAE $1 \mathrm{~b}$ black shale $2.09 \mathrm{~m}$ above the white chalk/gray claystone contact that marks the $P a$. eubejaouaensis extinction. While essentially no change in calcareous nannofossil assemblages was identified at the base of the black shale, a marked change in relative abundance and coccolith size was recorded by these authors at the white chalk/claystone contact. Assemblages from below this horizon are dominated by robust species indicative of oligotrophic environments (e.g., Watznaueria barnesiae, Nannoconus spp.), whereas assemblages above are abruptly replaced by small-sized, high-fertility indicator species (e.g., Zeugrhabdotus erectus, Biscutum ellipticum). Species evenness declines at the same level as the assemblage change, but species richness shows little change.

Restudy of samples from Site 390 reveals that cores 3 and 4 contain a planktic foraminiferal assemblage identical to that of the lowermost Albian at Site 1049. Thus, these cores are here assigned to the Mi. rischi Zone (Fig. 3). 


\section{DSDP Site 392}

Analysis of Core 392A-3 reveals that the Aptian/Albian boundary should be placed at a lithologic contact between an underlying yellowish-white nannofossil chalk and overlying dark grayish-green calcareous claystone at Sample 392A-3-2, $62 \mathrm{~cm}$ (79.62 mbsf) based on the presence of a Pa. eubejaouaensis in the chalk and Ti. primula in the overlying claystone. This marks the position of a major unconformity separating the upper Aptian Pa. eubejaouaensis Zone from the middle Albian Ticinella primula Zone (Fig. 3).

\section{DSDP Site 511}

The Aptian/Albian boundary at Site 511 is placed $486.14 \mathrm{mbsf}$ at the $\mathrm{HO}$ of $\mathrm{Pa}$. eubejaouaensis, which is represented by a single specimen in a bioturbated, graygreen, clay-rich nannofossil chalk bed at $37-46 \mathrm{~cm}$ in Section 55-5 (Figs. 9, 14; Table 2). The next sample studied below this level (486.22 mbsf) yields multiple specimens of $P a$. eubejaouaensis together with several specimens of $P a$. transitoria, $H d$. excelsa, and $H d$. aptiana and a single specimen of $H d$. infracretacea. The next sample above the boundary level contains only $H d$. praelippa and $M i$. miniglobularis. Assemblages in all of these samples are very well preserved with some specimens showing glassy preservation.

Significant changes in the foraminiferal assemblages occur within 9.39 m below the Pa. eubejaouaensis extinction level with a precipitous drop from $92 \%$ to $11 \%$ planktic foraminifera followed by a further decrease to $<1 \%$ between $0.37 \mathrm{~m}$ below and $0.19 \mathrm{~m}$ above the boundary level (Fig. 9). Planktic foraminifera do not reach their preboundary relative abundance levels of $>90 \%$ until $\sim 26 \mathrm{~m}$ above the $P a$. eubejaouaensis extinction. This drop in percent planktic foraminifera is not accompanied by evidence for increased dissolution or a decrease in water depth, but coincidence between this change in foraminiferal assemblages with a significant increase in the abundance of micro-bivalve fragments suggests that significant changes in the bottom-water paleoenvironment may have occurred at this time.

Accompanying the extinction of the late Aptian planktic species is an abrupt and dramatic decrease in the range of maximum test diameters (Fig. 9). Below the Pa. eubejaouaensis extinction the mean test diameters of all species present range 200-300 $\mu \mathrm{m}$, whereas species occurring within in the overlying $1 \mathrm{~m}$ average $80-100 \mu \mathrm{m}$. Test diameters averaging $>200 \mu \mathrm{m}$ do not occur until nearly $30 \mathrm{~m}$ above the Pa. eubejaouaensis extinction.

\section{DSDP Site 545}

Our study of Site 545 (Table 3; Fig. 24) reveals that previous placement of the Aptian/Albian boundary at 390.75 mbsf by Bralower and others (1997) was $14.75 \mathrm{~m}$ too low, and the black shale at 390.45 mbsf interval in Core 545-42-1 and -2, which had been identified as the early Albian OAE 1b Paquier event (Herrle and others, 2004;
Friedrich and others, 2005; Wagner and others, 2008), is actually latest Aptian in age. Foraminifera are moderately to well preserved in the Aptian samples, but planktic foraminifera are absent or, when present, very rare (Leckie, 1984; Leckie and others, 2002). Because planktic foraminifera are absent or occur as $<1 \%$ of the total assemblage in Aptian samples above $401 \mathrm{mbsf}, P a$. eubejaouaensis is difficult to find, and it is recorded sporadically from Core 545-47-1, 93-95 cm to -40R-6, 60-62 cm (Fig. 24; Table 3). Paraticinella transitoria also occurs in the latter sample and in the next sample $19 \mathrm{~cm}$ above together with rare and sporadic $H d$. infracretacea, $H d$. gorbachikae, and $\mathrm{Gl}$. aptiensis, which forms the basis for the late Aptian age assignment up to $377.11 \mathrm{mbsf}$.

A major unconformity separates the sample with the $\mathrm{HO}$ of Pa. transitoria and the next overlying sample studied (545-40R-5, 8-10 cm) that yields biomarkers of the Rotalipora subticinensis Zone (Leckie, 1984). There are multiple intervals in Core 40 containing intraclastic flat pebble and cobble claystone conglomerate; the lowest of these beds is in Core 40-5, 90-130 cm. This latter interval marks the unconformity formed by erosion and slump deposits at the base of the Mazagan Plateau (Hinz and others, 1984; Leckie, 1984). Planktic foraminiferal abundance is much higher in the upper Albian samples, comprising $>90 \%$ of the total assemblage (Leckie, 1984; Leckie and others, 2002).

\section{ODP Hole $763 B$}

The Aptian/Albian boundary in Hole 763B should be placed between the $\mathrm{HO}$ of $\mathrm{Pa}$. transitoria at $529.45 \mathrm{mbsf}$ (763B-37X-5, 95-97 cm) and the LO of Mi. rischi at 528.73 mbsf (763B-37X-5, 23-25 cm). The Aptian assemblage, which varies in abundance and degrees of shell recrystallization and test infilling by calcite, is assigned to the upper Aptian Pa. eubejaouaensis Zone based on the occurrence of the nominate taxon or the closely related $P a$. transitoria and absence of these species from the core samples above. It should be noted that both species of Paraticinella are very rare, causing some uncertainty in zonal and age assignment above and below their recorded range. The Aptian assemblage is dominated by $H d$. infracretacea, $H d$. excelsa, and $H d$. gorbachikae. As observed at Site 511, the LO of Hd. praelippa is in the uppermost Aptian of Hole 763B at 530.23 mbsf (37X-CC, $23-25 \mathrm{~cm})$.

Sample 763B-37X-5, 23-25 cm is assigned to the $M i$. rischi Zone based on the presence of the nominate species, abundance of Mi. praeplanispira and Mi. pseudoplanispira, and absence of biomarkers for younger Albian intervals (Fig. 25). Absence of the Mi. miniglobularis Zone forms the basis for placing an unconformity between this sample and the next sample $0.72 \mathrm{~m}$ below, although no physical evidence for an unconformity is obvious in the core. The Albian assemblages are generally better preserved than those in the Aptian and include specimens with glassy, hollow tests. A single specimen of Pa. eubejaouaensis found at $522.85 \mathrm{mbsf}$ is considered reworked because of its absence from all samples taken within the $6.6 \mathrm{~m}$ interval between this level and the last consistent occurrence of 


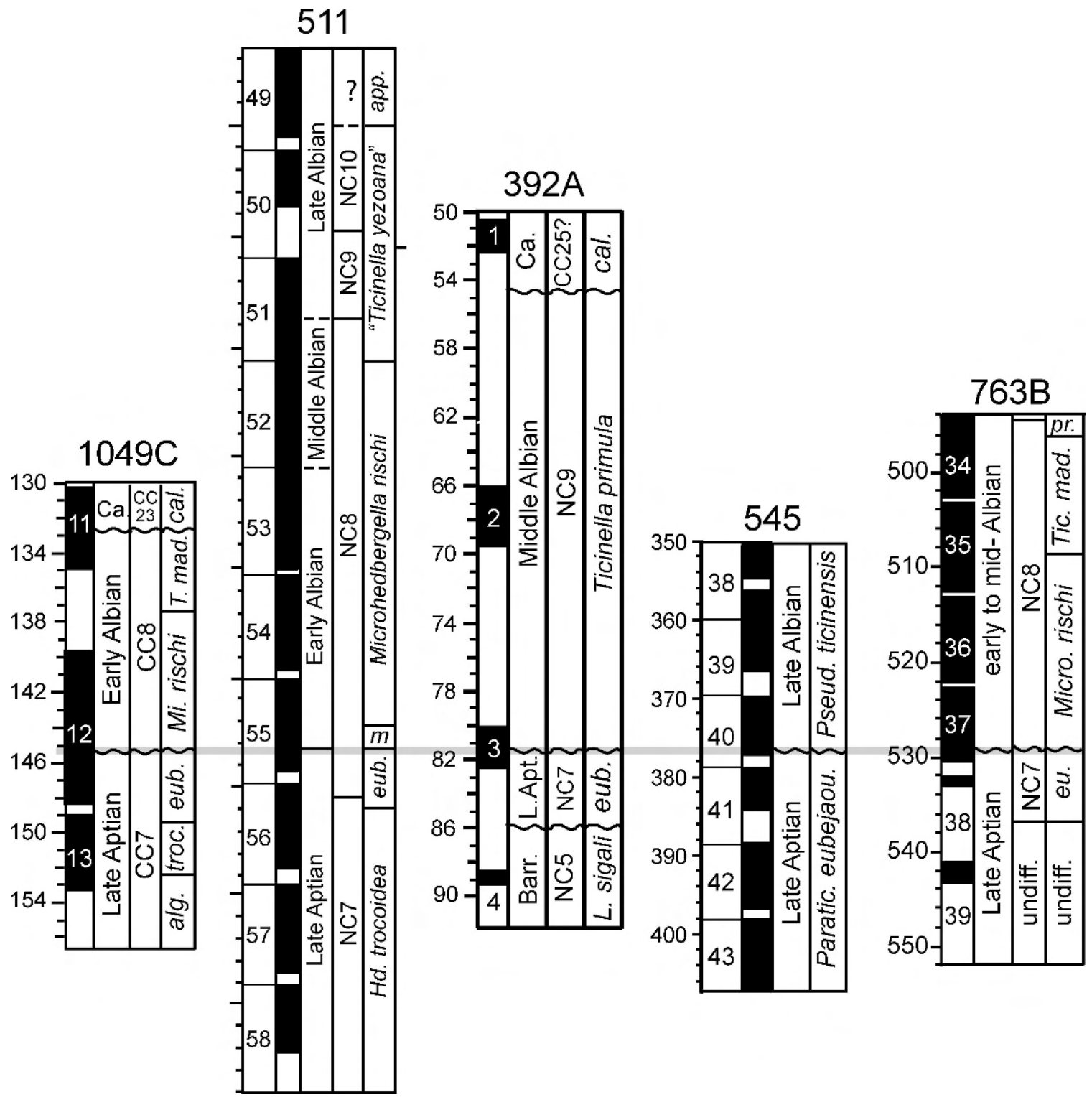

FIGURE 22. Correlation of Aptian/Albian boundary DSDP and ODP sequences analyzed in this study. Each section shows, from left to right, core depth (meters below seafloor), core number, core recovery (black), calcareous nannofossil and planktonic foraminiferal biozones. Wavy lines represent position of unconformities.

paraticinellids at $529.45 \mathrm{mbsf}$. The persistence of other rare Aptian taxa ( $H d$. infracretacea, $H d$. excelsa, and $H d$. gorbachikae) as high as sample 763B-36X-CC, 23-25 cm also suggests the possibility of sediment reworking through the basal Albian at this site. However, the possibility that "Aptian" taxa bearing the perforation cone microstructure may have co-existed for a short time with microperforate Albian taxa at Site 763 cannot be rejected. Resolution of this stratigraphic overlap problem will require additional study and documentation.

\section{SUMMARY AND CONCLUSIONS}

The details of the major extinction of planktic foraminifera across the AABI has hitherto been overlooked because of prevalent inconsistency in the usage of taxonomic concepts, incompleteness of stratigraphic sections across this interval, and frequent poor foraminiferal preservation, making species identification difficult. Recovery of deep-sea sections yielding well-preserved foraminiferal assemblages above and below the boundary level provided an opportunity to carefully document the taxonomic and phylogenetic changes that took place. Study of four of these sections has led to substantial revision of the taxonomy and phylogeny of the Lower Cretaceous Hedbergellidae with the naming of one new genus (Pseudoguembelitria) and two new species (Ps. blakenosensis, Hedbergella praelippa) that originated in the Late Aptian, and two new genera (Microhedbergella, Muricohedbergella) and five new species (Mi. miniglobularis, Mi. renilaevis, Mi. praeplanispira, Mi. pseudoplanispira, $M u$. pseudodelrioensis) that originated within the Aptian/Albian 


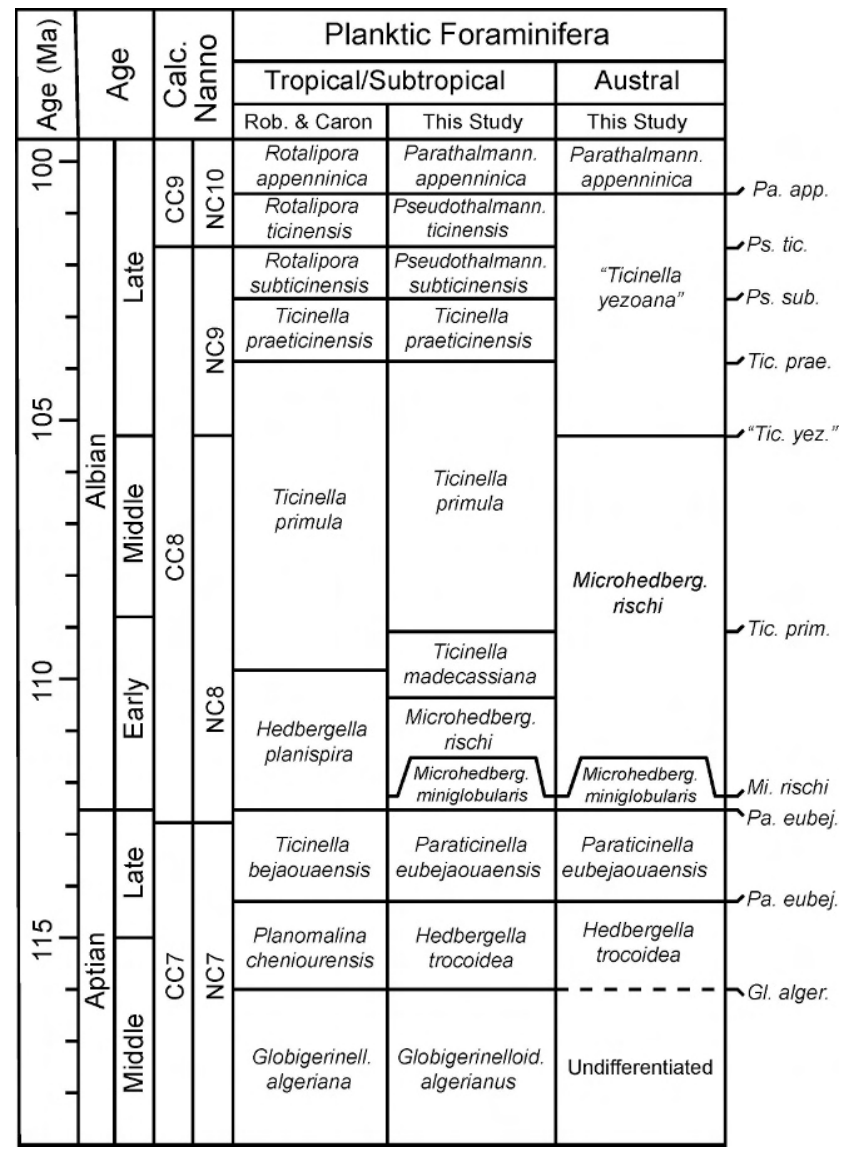

Figure 23. Comparison of tropical/subtropical zonal scheme used by Robaszynski and Caron (1995) with that proposed in this study and with the Austral zonal scheme developed based on study of Site 511. Datum events used to define the base of each zone are shown to the right, with upward pointing ticks for LOs and downward pointing ticks for HOs. Age estimates for the Robaszynski and Caron (1995) zones, calcareous nannofossils zones and the stage and substage boundaries are produced from TSCreator (http://www.tscreator.org) and are standardized to the geologic time scale of Gradstein and others (2004).

boundary interval and early to middle Albian. A new subfamily, the Paraticinellinae, is also named in the present study to include late Aptian species of Paraticinella.

Continuous sedimentation across the AABI is rare, as it is often marked by an unconformity (e.g., Amedro, 1992) or dissolution (e.g., Leckie, 1984; Torghanhi and others, 1989) in deeper water sections or ecological collapse in shallow carbonate-platform sections (e.g., Föllmi and others, 2006; Iba and Sano, 2007). The Aptian/Albian boundary unconformities at Sites 545, 763, and 1049 provide further evidence for a global environmental perturbation at the boundary level.

Correlation of the studied deep-sea AABI sections is presented in Figure 22. The most complete stratigraphic record across the AABI occurs at DSDP Site 511. This extinction is marked by loss of species with thick shell walls and surface textures characterized by perforation cones and coalescing pustules, and by a dramatic decrease in shell size from a mean of $245 \mu \mathrm{m}$ in the latest Aptian to $80 \mu \mathrm{m}$ in the earliest Albian. A sudden drop in the relative abundance of planktic foraminifera from generally $>90 \%$ of the total assemblage to $<12 \%$ occurs $9.4 \mathrm{~m}$ below the boundary level

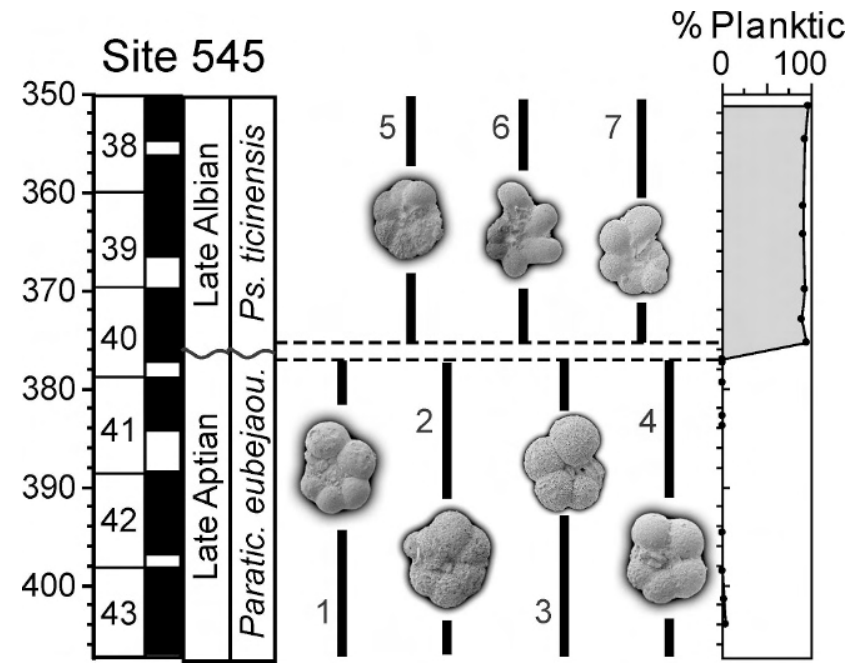

FIGURE 24. Biostratigraphic ranges and percent planktic foraminifera across the Aptian/Albian boundary interval at DSDP Site 545. See caption of Figure 3 for explanation of core depth, core recovery, and biozones. Species illustrated with their ranges are from the following samples: (1) Globigerinelloides aptiense (545-40-6, 60-62 cm); (2) Paraticinella transitoria (545-41-1, 40-42); (3) Hedbergella infracretacea (545-40-6, 60-62 cm); (4) Hedbergella occulta (545-41-1, 40$42 \mathrm{~cm})$; (5) Rotalipora subticinensis $(545-40-5,8-10 \mathrm{~cm})$; (6) Ticinella digitalis (545-40-5, 8-10 cm); (7) Ticinella raynaudi $(545-40-5,8-10 \mathrm{~cm})$.

and drops to nearly $0 \%$ within $0.56 \mathrm{~m}$ below this horizon. The species $H d$. praelippa survives across the AABI, and is tentatively considered ancestral to the Microhedbergella lineage, whose oldest species Mi. miniglobularis evolved within $0.6 \mathrm{~m}$ below the $\mathrm{HO}$ of $\mathrm{Pa}$. eubejaouaensis. The Mi. miniglobularis Zone at Site 511 is defined for an interval $(\sim 1 \mathrm{~m}$ thick) immediately above the AABI extinction and comprises the evolutionary transition from Mi. miniglobularis to Mi. renilaevis, and the extinction of $\mathrm{Hd}$. praelippa. The ensuing Albian planktic foraminiferal record at Site 511, which includes the Mi. rischi Zone and is overlain by the "Ticinella yezoana" Zone, is represented by the gradual evolution of several more species of Microhedbergella and, in the late Albian, Muricohedbergella. This gradual diversity increase is accompanied by a slow increase in mean and maximum shell sizes.

The AABI at ODP Site 1049 also records an abrupt extinction of Aptian species, a decrease in the relative abundance of planktic foraminifera, and a decrease in shell size from a mean of $232 \mu \mathrm{m}$ in the uppermost Aptian to a mean of $130 \mu \mathrm{m}$ in the lower Albian. Absence of the Mi. miniglobularis Zone assemblage, however, and coincidence of the Aptian species extinction with a sharp lithologic break indicates the presence of an unconformity across the Aptian/ Albian boundary interval. Only two species, Mi. renilaevis and Mi. rischi, are present in most of the lower Albian Mi. rischi Zone, as the LOs of Mi. praeplanispira and Mi. pseudoplanispira are not until the upper part of this zone. The gradual evolutionary transition at Site 1049 of Mi. rischi to Ti. madecassiana is accompanied by a gradual increase in test diameter to a mean of $200 \mu \mathrm{m}$ in the Ti. madecassiana Zone. An unconformity between the latter zone and the overlying Radotruncana calcarata Zone has removed the upper Albian-lower Campanian record at Site 1049. 


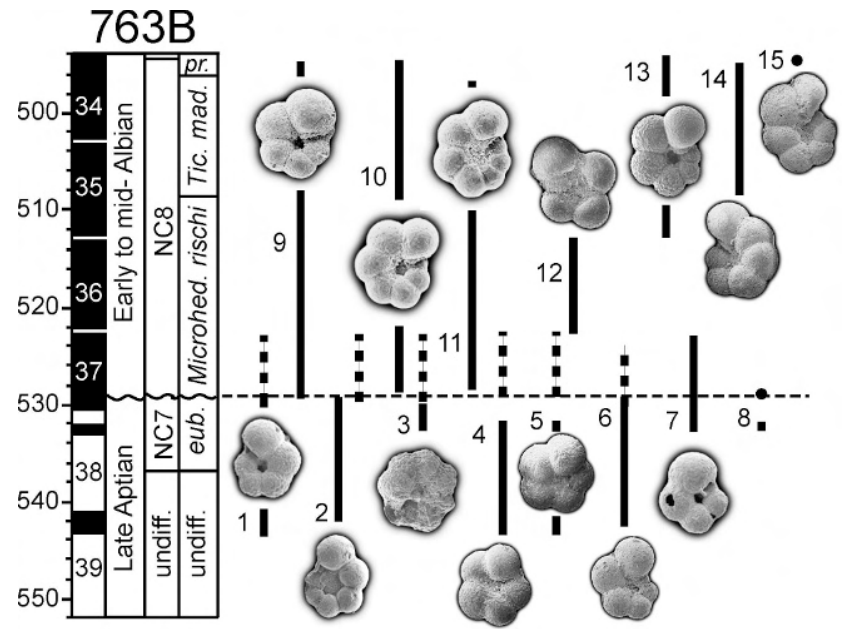

FIGURE 25. Biostratigraphic ranges of important planktic foraminiferal biomarker species across the Aptian/Albian boundary interval at DSDP Site 763. See caption of Figure 3 for explanation of core depth, core recovery, and biozones. Species illustrated with their ranges are from the following samples: (1) Hedbergella infracretacea (763B38R-1, 75-77 cm); (2) Globigerinelloides aptiensis (763B-39R-1, 44 $46 \mathrm{~cm})$; (3) Paraticinella transitoria (763B-37R-5, 95-97 cm); (4) Hedbergella excelsa (763B-38-1, 25-27 cm); (5) Hedbergella gorbachikae (763B-38R-1, 25-27 cm); (6) Hedbergella aptiana (763B-37R-1, 23$25 \mathrm{~cm}$ ); (7) Hedbergella praelippa (763B-38R-1,75-77 cm); (8) Hedbergella occulta; (9) Microhedbergella rischi (763B-36R-3, 45$47 \mathrm{~cm})$; (10) Microhedbergella praeplanispira (763B-36R-3, 45-47 cm); (11) Microhedbergella pseudoplanispira (763B-36R-3, 45.5-47.5 cm); (12) Microhedbergella renilaevis (763B-37R-1, 23-25 cm); (13) Muricohedbergella planispira (763B-34R-1, 65-67 cm) (14) Ticinella madecassiana (763B-35R-3, 23-25 cm); (15) Ticinella primula (763B34R-1, 22-24 cm). Calcareous nannofossil biozonation from Bralower et al. (1997).

Despite previous reports of a complete AABI at DSDP Site 545, and a black shale sequence in the lower Albian designated as Oceanic Anoxic Event 1b, our study reveals the presence of a major unconformity spanning from the uppermost Aptian to the upper Albian. The AABI at Site 763 is marked by absence of the Mi. miniglobularis Zone, suggesting that an unconformity separates the uppermost Aptian and lowermost Albian. However, the pattern of species occurrences at Site 763 differs from Site 511 in that Mi. praeplanispira and Mi. pseudoplanispira may occur below the LO of Mi. rischi. Resolution of this discrepancy will require further effort to locate better-preserved foraminifera from the uppermost Aptian and basal Albian of Site 763, as test recrystallization and infilling have largely obliterated the Aptian wall microstructures of the specimens studied so far. The global reduction in the relative abundance of planktic foraminifera followed by abrupt extinction of Aptian species (including a dramatic decrease in shell size, maximum shell thickness, and shell ornamentation) is accompanied by a decrease in abundance of robust, oligotrophic environmental indicator species of calcareous nannofossils and replacement by small-sized, high fertility indicator species (Browning and Watkins, 2008). This suggests a common cause, which may have been related to a change in the carbonate chemistry of the mixed layer, making shell calcification more difficult. Other changes in the mixed layer, such as the rate of vertical mixing and reduced vertical stratification, and changes in nutrient supply and surface productivity, may also account for the species turnover across the AABI. The excellent preservation of thin-walled shells with a high surface area to volume ratio negates the possibility of increased acidity of the mixed layer as a causal mechanism.

Presence of a widespread unconformity across the AABI suggests that whatever caused changes in the planktic foraminiferal assemblages may have also led to increased rates of bottom-water circulation or corrosion that, in some regions, resulted in scouring or nondeposition near the end of the Aptian. In the absence of evidence for shell dissolution, a decrease in $\mathrm{pH}$ is not considered a likely explanation for the major turnover in the planktic foraminifera. Understanding the cause or causes of the oceanographic changes will require detailed investigation of changes in benthic foraminiferal populations, high-resolution oxygen, carbon, and strontium isotopic analyses, and acquisition of additional geochemical paleoenvironmental proxies.

\section{ACKNOWLEDGMENTS}

This research used samples and data provided by the Integrated Ocean Drilling Program (IODP). IODP is sponsored by the U.S. National Science Foundation (NSF) and participating countries under the management of IODP Management International, Inc. We thank members of the Mesozoic Planktonic Foraminiferal Working Group and especially Maria Rose Petrizzo, Isabella Premoli Silva, and Atsushi Ando for many fruitful discussions and ideas. We also thank Isabella Premoli Silva, Michèle Moullade, and Atsushi Ando for their very thorough and thoughtful reviews, Ken Finger for numerous helpful editorial suggestions, Michèle Caron for providing samples from the Vocontian Basin, JoAnn Sanner for some of the SEM image editing, and Ken MacLeod for analyzing samples in his stable isotope laboratory. RML would like to thank Richard Cashman for laboratory assistance. This study was supported by a grant to BTH from the Smithsonian Institution's Walcott Fund. Acknowledgment is made to the donors to the Petroleum Research FundAmerican Chemical Society for research support to RML.

\section{REFERENCES}

Agalarova, D. A., 1951, Studies of Microfauna from Cretaceous Deposits of Azerbaydzhan in Djafarov, D. I., Agalarova, D. A., and Khalilov, D. M. (eds.), Reference Book on the Lower Cretaceous Microfauna of Azerbaijan Sedimentary Rocks: Azmefteozdat, Baku, 128 p. (In Russian)

AmÉDro, F., 1992, L'Albien du Bassin Anglo-Parisien: ammonites, zonation phylétique, séquences: Bulletin des Centres de Recherches Exploration-Production, Elf Aquitaine, v. 16, p. 187-233.

BANner, F. T., and Desai, D., 1988, A review and revision of the Jurassic-Early Cretaceous Globigerinina, with especial reference to the Aptian assemblages of Speeton (North Yorkshire, England): Journal of Micropaleontology, v. 7, p. 143-185.

-, Copestake, P., and White, M. R., 1993, Barremian-Aptian Praehedbergellidae of the North Sea area: a reconnaisance: Bulletin of the Natural History Museum, London (Geology), V. 49, p. 1-30.

Barker, C. E., Pawlewicz, M., and Cobabe, E. A., 2001, Deposition of sedimentary organic matter in black shale facies indicated by 
the geochemistry and petrography of high-resolution samples, Blake Nose, Western North Atlantic, in Kroon, D., Norris, R. D., and Klaus, A. (eds.), Western North Atlantic Palaeogene and Cretaceous Palaeoceanography. Geological Society of London, Special Publication No. 183, London, p. 49-72.

Bartenstein, H., 1965, Taxonomische revision und nomenklator zu Franz E. Hecht "Standard-Gliederung der Nordwest-deutschen Unterkriede nach Foraminiferen" (1938). Teil 4, Alb, mit Beschreibungen von Arten aus verschiedenen Unterkreide-Niveaus: Senckenbergiana Lethaea, v. 46, p. 327-366.

Basov, I. A., and Krasheninnikov, V. A., 1983, Benthic foraminifers in Mesozoic and Cenozoic sediments of the southwestern Atlantic as an indicator of paleoenvironment, Deep Sea Drilling Project Leg 71, in Ludwig, W. J., Krasheninnikov, V. A., and others. (eds.), Initial Reports of the Deep Sea Drilling Project, v. 71: U.S. Government Printing Office, Washington, D.C., p. 739-787.

Bellier, J.-P., and Moullade, M., 2002, Lower Cretaceous planktic foraminiferal biostratigraphy of the western North Atlantic (ODP Leg 171B), and taxonomic clarification of some key index species: Revue de Micropaléontologie, v. 45, p. 9-26.

- - , and Huber, B. T., 2000, Mid-Cretaceous planktic foraminifers from Blake Nose: revised biostratigraphic framework, in Norris, R. D., Kroon, D., and Klaus, A. (eds.), Proceedings of the Ocean Drilling Program, Scientific Results, v. 171B: Ocean Drilling Program, College Station, Texas. <http:// www-odp.tamu.edu/publications/171B_SR/chap_03/chap $>$

Benson, W. E., and Sheridan, R. E., Shipboard Scientific Party (eds.), 1978, Initial Reports of the Deep Sea Drilling Project, v. 44: U.S. Government Printing Office, Washington, D.C., p. 1-1005.

Birkelund, T., Hancock, J. M., Hart, M. B., Rawson, P. F., Remane, J., RobaszynSki, F., Schmid, F., and Surlyk, F., 1984, Cretaceous stage boundaries - proposals: Bulletin of the Geological Society of Denmark, v. 33, p. 3-20.

BouDagher-Fadel, M. K., Banner, F. T., Whittaker, J. E., and Simmons, M. D., 1997, The Early Evolutionary History of Planktic Foraminifera: Chapman and Hall, Cambridge, UK, $269 \mathrm{p}$.

Bralower, T. J., Fullagar, P. D., Paull, C. K., Dwyer, G. S., and LECKIE, R. M., 1997, Mid-Cretaceous strontium-isotope stratigraphy of deep-sea sections: Geological Society of America Bulletin, v. 109, p. 1421-1442.

-, Sliter, W., Arthur, M., Leckie, R. M., Allard, D., and Schlanger, S. O., 1993, Dysoxic/anoxic episodes in the AptianAlbian (Early Cretaceous), in Pringle, M., Sager, W. W., Sliter, W., and Stein, S. (eds.), Mesozoic of the Pacific. American Geophysical Union, Geophysical Monograph 77, p. 5-37.

Bréhéret, J. G., 1997, L'Aptien et l'Albien de la Fosse vocontienne (des bordures au bassin). Evolution de la sédimentation et enseignmements sur les événements anoxiques: Société Géologique de Nord, Publication, v. 25, 625 p.

- Caron, M., and Delamette, M., 1986, Niveaux riches en matière organique dans l'Albien Vocontien; quelques caractères $\mathrm{du}$ paleoenvironnement; essai d'interpretation genetique: Documents du Bureau des Recherches Géologiques et Minières, v. 110, p. 141-191.

Brönnimann, P., and Brown, N. K., 1958, Hedbergella, a new name for a Cretaceous planktic foraminiferal genus: Journal of the Washington Academy of Sciences, v. 48, p. 15-17.

Browning, E. L., and Watkins, D. K., 2008, Elevated primary productivity of calcareous nannoplankton associated with ocean anoxic event $1 \mathrm{~b}$ during the Aptian/Albian transition (Early Cretaceous): Paleoceanography, v. 23, p. PA2213. doi:10.1029/ 2007PA001413.

CARON, M., 1978, Cretaceous planktonic foraminifera from DSDP Leg 40, southeastern Atlantic Ocean, in Bolli, H. M., Ryan, W. B. F., and others, (eds.), Initial Reports of the Deep Sea Drilling Project: U.S. Government Printing Office., Washington, D.C., v. 40, p. 651-678.

- 1985, Cretaceous planktonic foraminifera, in Bolli, H. M., Saunders, J. B., and Perch-Neilsen, K. (eds.), Plankton Stratigraphy: Cambridge University Press, Cambridge, UK, p. 17-86.

Carsey, D. O., 1926, Foraminifera of the Cretaceous of central Texas: University of Texas Bulletin, v. 2612, p. 1-56.
Coccioni, R., and Premoli Silva, I., 1994, Planktonic foraminifera from the Lower Cretaceous of Rio Argos sections (southern Spain) and biostratigraphic implications: Cretaceous Research, v. 15 , p. $645-687$.

- - MArsili, A., and Verga, D., 2007, First radiation of Cretaceous planktonic foraminifera with radially elongate chambers at Angles (southeastern France) and biostratigraphic implications: Revue de Micropaléontologie, v. 50, p. 215-224.

Cushman, J. A., 1933, Some new foraminiferal genera: Contributions from the Cushman Laboratory for Foraminiferal Research, v. 9, p. 32-38.

Dupeuble, P. A., 1979, Mesozoic foraminifers and microfacies from Holes 400A, 401 and 402A of the DSDP Leg 48, in Montadert, L., and Roberts, D. G., Shipboard Scientific Party (eds.), Initial Reports of Deep Sea Drilling Project, v. 48: U.S. Government Printing Office, Washington, D.C., p. 451-473.

Erbacher, J., Huber, B. T., Norris, R. D., and Markey, M., 2001, Increased thermohaline stratification as a possible cause for an oceanic anoxic event in the Cretaceous Period: Nature, v. 409, p. $325-327$.

Föllmi, K. B., Godet, A., Bodin, S., and Linder, P., 2006, Interactions between environmental change and shallow water carbonate buildup along the northern Tethyan margin and their impact on the Early Cretaceous carbon isotope record: Paleoceanography, v. 21, PA4211, doi:10.1029/2006PA001313.

Friedrich, O., Nishi, H., Pross, J., Schmiedl, G., and Hemleben, C., 2005, Millennial- to centennial-scale interruptions of the Oceanic Anoxic Event 1b (early Albian, mid-Cretaceous) inferred from benthic foraminiferal repopulation events: Palaios, v. 20, p. 64-77.

GANDOLFI, R., 1942, Ricerche micropaleontologiche e stratigraphfiche sulla Scaglia e sul flysch Cretacici dei Dintorni di Balerna (Canton Ticino): Rivista Italiana Paleontologia, v. 48, p. 1-160.

GEORGESCU, M. D., 2007a, A new planktic heterohelicid foraminiferal genus from the Upper Cretaceous (Turonian): Micropaleontology, v. 53 , p. $212-220$.

_ 2007b, Taxonomic re-evaluation of the Late Cretaceous serial planktic foraminifer Gümbelina punctulata Cushman, 1938 and related species: Revista Española de Micropaleontología, v. 39, p. $1-14$.

, 2008, A new planktonic foraminifer (Family Hedbergellidae Loeblich and Tappan, 1961) from the lower Campanian sediments of the Falkland Plateau, South Atlantic Ocean (DSDP Site 511): Journal of Foraminiferal Research, v. 38, p. 157-161.

, 2009, On the origins of superfamily Heterohelicacea Cushman, 1927 and the polyphyletic nature of planktic foraminifera: Revista Española de Micropaleontología, v. 41, p. 107-144.

- and Abramovich, S., 2008, Taxonomic revision and phylogenetic classification of the Late Cretaceous (upper Santonian-Maastrichtian) serial planktic foraminifera (family Heterohelicidae Cushman, 1927) with peripheral test wall flexure: Revista Espańola de Micropaleontología, v. 40, p. 97-114.

- , and Huber, B. T., 2006, Paracostellagerina nov. gen., a meridionally costellate planktonic foraminiferal genus of the Middle Cretaceous (late Albian-earliest Cenomanian): Journal of Foraminiferal Research, v. 36, p. 368-373.

, and -2007 , Taxonomic revision of the late CampanianMaastrichtian (Late Cretaceous) planktic foraminiferal genus Rugotruncana Brönnimann and Brown, 1956, and a new paleontological species concept for planktic foraminifera: Journal of Foraminiferal Research, v. 37, p. 150-159.

— and - 2009, Early evolution of the Cretaceous serial planktic foraminifera (late Albian-Cenomanian): Journal of Foraminiferal Research, v. 39, p. 335-360.

- SAupe, E., and Huber, B. T., 2009, Taxonomic revision of the Late Cretaceous (late Campanian-Maastrichtian) serial planktic foraminiferal genus Gublerina Kikione, 1948: Micropaleontology, v. 54 , p. $397-424$.

Glaessner, M. F., 1937, Studien über Foraminiferen aus der Kreide und dem Tertiär des Kaukasus. I. Die Foraminiferen der ältesten Tertiärschichten des Nordwest-Kaukasus: Problemy Paleontologii, Paleontologicheskay Laboratoriya Moskovskogo Gosudarstvennogo Universiteta, v. 2-3, p. 349-410. 
Gorbatchik, T. N., and Moullade, M., 1973, Caractères microstructuraux de la paroi du test des foraminifères planctoniques du Crétacé inférieur et leur signification sure le plan taxinomique: Compte Rendus de l'Académie des Sciences, Paris (Série D), v. 277 , p. $2661-2664$.

Gradstein, F. M., 1978, Biostratigraphy of Lower Cretaceous Blake Nose and Blake-Bahama Basin foraminifers, DSDP Leg 44, western North Atlantic Ocean, in Worstell, P. (ed.), Initial Reports of the Deep Sea Drilling Project, v. 44: U.S. Government Printing Office, Washington, D.C., p. 663-701.

, OGG, J. G., and Smith, A. G., 2004, A Geologic Time Scale 2004: Cambridge University Press, Cambridge, UK, $589 \mathrm{p}$.

HAIG, D. W., 1992, Aptian-Albian foraminifers from Site 766, Cuvier Abyssal Plain, and comparison with coeval faunas from the Australian region, in Gradstein, F. M., and Ludden, J. N., Shipboard Scientific Party (eds.), Proceedings of the Ocean Drilling Program, Scientific Results, v. 123: Ocean Drilling Program, College Station, Texas, p. 271-297.

Hancock, J. M., 1991, Ammonite scales for the Cretaceous System: Cretaceous Research, v. 12, p. 259-291.

_ 2001, A proposal for a new position for the Aptian/Albian boundary: Cretaceous Research, v. 22, p. 677-683.

HaQ, B. U., von Rad, U., and O'Connell, S., Shipboard Scientific PARTY (eds.), 1990, Proceedings of the Ocean Drilling Program, v. 122: Ocean Drilling Program, College Station, Texas, 826 p.

Hart, M. B., Amédro, F., and Owen, H. G., 1996, The Albian stage and substage boundaries: Bulletin de l'Institut Royal des Sciences Naturelles de Belgique, Sciences de la Terre, v. 66 (Supplément), p. $45-56$.

Hay, W. W., DeConto, R., Wold, C. N., Wilson, K. M., Voigt, S., Schulz, M., Wold-Rossby, A., Dullo, W.-C., Ronov, A. B., Balukhovsky, A. N., and SöDing, E., 1999, Alternative global Cretaceous paleogeography, in Barrera, E., and Johnson, C. (eds.), Evolution of the Cretaceous Ocean-Climate System. Geological Society of America Special Paper 332, p. 1-47.

Неснт, F. E., 1938, Standard-Gliederung der Norwestdeutschen Unterkreide nach Foraminiferen: Abhandlungen von der Seckenbergischen Naturforschenden Gesellschaft, v. 443, p. 3-42.

Hemleben, C., Spindler, M., and Anderson, O. R., 1989, Modern Planktic Foraminifera: Springer-Verlag, New York, 335 p.

Herrle, J. O., Kößler, P., Friedrich, O., Erlenkeuser, H., and Hemleben, C., 2004, High-resolution carbon isotope records of the Aptian to lower Albian from SE France and the Mazagan Plateau (DSDP Site 545): a stratigraphic tool for paleoceanographic and paleobiologic reconstruction: Earth and Planetary Science Letters, v. 218, p. 149-161.

, and Mutterlose, J., 2003, Calcareous nannofossils from the Aptian-lower Albian of southeast France: palaeoecological and biostratigraphic implications: Cretaceous Research, v. 24, p. 1-22.

Hinz, K., and Winterer, E. L., Shipboard Scientific Party (eds.), 1984, Initial Reports of the Deep Sea Drilling Project, v. 79: U.S. Government Printing Office, Washington, D.C., 934 p.

Holbourn, A., and Kunnt, W., 2001, No extinctions during Oceanic Anoxic Event 1b: the Aptian-Albian benthic foraminiferal record of ODP Leg 171, in Kroon, D., Norris, R. D., and Klaus, A. (eds.), Western North Atlantic Palaeogene and Cretaceous Palaeoceanography. Geological Society of London, Special Publication 183, p. 73-92.

Huber, B. T., 1994, Ontogenetic morphometrics of some Late Cretaceous trochospiral planktic foraminifera from the Austral Realm: Smithsonian Contributions to Paleobiology, v. 77, 85 p.

-, MacLeod, K. G., and TuR, N., 2008, Late CampanianMaastrichtian chronostratigraphic framework for CampanianMaastrichtian sediments on Blake Nose (subtropical North Atlantic): Journal of Foraminiferal Research, v. 38, p. 162-182.

, GRÖCKE, D. R., and KUCERA, M., in prep., Geochemical changes associated with Aptian/Albian boundary planktic foraminiferal extinction in the subtropical North Atlantic: Paleoceanography.

IBA, Y., and SANO, S., 2007, Mid-Cretaceous step-wise demise of the carbonate platform biota in the Northwest Pacific and establishment of the North Pacific biotic province: Palaeogeography, Palaeoclimatology, Palaeoecology, p. 462-482.
Jenkins, D. G., Whittaker, J. E., and Curry, D., 1998, Palaeogene triserial planktonic foraminifera: Journal of Micropalaeontology, v. 17 , p. $61-70$.

Kennedy, W. J., Gale, A. S., Bown, P. R., Caron, M., Davey, R. J., Gröcke, D., and WraY, D. S., 2000, Integrated stratigraphy across the Aptian-Albian boundary in the Marnes Bleues, at the Col de Pré-Guittard, Arnayon (Drôme), and at Tartonne (Alpesde-Haute-Provence), France: a candidate Global Boundary Stratotype Section and Boundary Point for the base of the Albian Stage: Cretaceous Research, v. 21, p. 591-720.

Krasheninnikov, V. A., and Basov, I. A., 1983, Stratigraphy of Cretaceous sediments of the Falkland Plateau based on planktonic foraminifers, Deep Sea Drilling Project, Leg 71, in Ludwig, W. J., Krasheninnikov, V. A., and others. (eds.), Initial Reports of the Deep Sea Drilling Project, v. 71: U.S. Government Printing Office, Washington, D.C., p. 789-820.

LeCKIE, R. M., 1984, Mid-Cretaceous planktic foraminiferal biostratigraphy off central Morocco, Deep Sea Drilling Project Leg 79, Sites 545 and 547, in Hinz, K., Winterer, E. L., and others. (eds.), Initial Reports of the Deep Sea Drilling Project, v. 79: U.S. Government Printing Office, Washington, D.C., p. 579620 .

1989, An oceanographic model for the early evolutionary history of planktonic foraminifera: Palaeogeography, Palaeoclimatology, Palaeoecology, v. 73, p. 107-138.

, 1990, Mid-Cretaceous planktic foraminifera of the Antarctic margin: Hole 693A, ODP Leg 113, in Barker, P. F., Kennett, J. P., and others. (eds.), Proceedings of the Ocean Drilling Program, Scientific Results, v. 113: Ocean Drilling Program, College Station, Texas, p. 319-324.

_ Bralower, T., and CASHMAN, R., 2002, Oceanic anoxic events and plankton evolution: Biotic response to tectonic forcing during the mid-Cretaceous. Paleoceanography, v. 17(3), 29 p. doi: 10.1029/2001PA000623

LeE, J. J., 1989, Phylum Granuloreticulosa (Foraminifera), in Margulis, L., Corliss, J. O., Melkonian, M., and Champman, D. J. (eds.), Handbook of Protoctista: Jones and Bartlett Publishers, Boston, p. 524-548.

Lipson-Benitah, S., and Almogi-Labin, A., 2004, Aptian planktic foraminifera from Israel: Israel Journal of Earth Sciences, v. 53, p. $27-46$.

Loeblich, A. R., JR., and TAPPAn, H., 1961, Cretaceous planktic foraminifera: Part I-Cenomanian: Micropaleontology, v. 7, p. $257-304$.

, and $\longrightarrow$, 1987, Foraminiferal Genera and Their Classification (2 v.): Van Nostrand Reinhold Co., New York, 970 p.

LONGORIA, J. F., 1974, Stratigraphic, morphologic and taxonomic studies of Aptian planktic foraminifera: Revista Espańola de Micropaleontología, v. Numero Extraordinario, p. 5-107.

— the Sabinas Basin of northern Mexico: Actes du VIe Colloque Africain de Micropaleontologie, Tunis, v. 28, p. 39-71.

Marianos, A. W., and Zingula, R. P., 1966, Cretaceous planktic foraminifers from Dry Creek, Tehama County, California: Journal of Paleontology, v. 40, p. 328-343.

McArthur, J. M., Howarth, R. J., and Bailey, T. R., 2001, Strontium isotope stratigraphy: LOWESS version 3: Best fit to the marine Sr-isotope curve for 0-509 Ma and accompanying look-up table for deriving numerical age: Journal of Geology, v. 109, p. $155-170$.

Mesozoic Planktonic Foraminiferal Working Group (Huber, B.T., COORD.), 2006, Mesozoic Planktonic Foraminiferal Taxonomic Dictionary, www.chronos.org.

Moullade, M., 1960, Sur quelques foraminifères du Crétacé inférieur des Baronnies (Drôme): Revue de Micropaléontologie, v. 2, p. $131-142$.

, 1961, Quelques foraminifères et ostracodes nouveaux du Crétacé inférieur des Baronnies (Drôme): Revue de Micropaléontologie, v. 3, p. 213-216.

, 1966, Etude stratigraphique et micropaleontologique du Crétacé inférieur de la "fosse vocontienne": Documents des Laboratoires de Géologie de la Faculté des Sciences de Lyon, v. 15, p. $1-369$. 
1974, Zones de foraminifères du Crétacé inféreur mesogéen: Comptes Rendus de l'Académie des Sciences, Paris (Série D), v. 278, p. 1813-1816.

, Bellier, J.-P., and Tronchetti, G., 2002, Hierarchy of criteria, evolutionary processes and taxonomic simplification in the classification of Lower Cretaceous planktic foraminifera: Cretaceous Research, v. 23, p. 111-148.

Norris, R. D., Kroon, D., and Klaus, A., Shipboard Scientific PARTY (eds.), 1998, Proceedings of the Ocean Drilling Program: Initial Reports, v. 171B: Ocean Drilling Program, College Station, Texas, $749 \mathrm{p}$.

OgG, J. G., and BArdot, L., 2001, Aptian through Eocene magnetostratigraphic correlation of the Blake Nose transect (Leg 171B), Florida continental margin, in Kroon, D., Norris, R. D., and Klaus, A. (eds.), Proceedings of the Ocean Drilling Program, Scientific Results, v. 171B: Ocean Drilling Program, College Station, Texas, p. 1-59 [CD-ROM].

Olsson, R. K., Berggren, W. A., Hemleben, C., and Huber, B. T., 1999, Atlas of Paleocene Planktic Foraminifera, Smithsonian Contributions to Paleobiology, v. 85, p. 1-252.

Owen, H. G., 2002, The base of the Albian Stage; comments on recent proposals: Cretaceous Research, v. 23, p. 1-13.

Pearson, P. N., Olsson, R. K., Hemleben, C., Huber, B. T., and Berggren, W. A., 2006, Atlas of Eocene Planktic Foraminifera, Cushman Foundation Special Publication No. 41, 513 p.

Petrizzo, M. R., and Huber, B. T., 2006, Biostratigraphy and taxonomy of late Albian planktic foraminifera from ODP Leg 171B (western North Atlantic Ocean): Journal of Foraminiferal Research, v. 36, p. 166-190.

— $\longrightarrow$, Wilson, P. A., and MacLeod, K. G., 2008, Late Albian paleoceanography of the western subtropical North Atlantic: Paleoceanography, v. 23, p. PA1213. doi:10.1029/ 2007PA001517.

Pflaumann, U., Krasheninnikov, V. A., 1977, Early Cretaceous planktonic foraminifers from eastern North Atlantic, DSDP Leg 41, in Lancelot, Y., and Seibold, E., Shipboard Scientific Party (eds.), Initial Reports of the Deep Sea Drilling Project, v. 41: U.S. Government Printing Office, Washington, D.C., p. 539-564.

Premoli Silva, I., Caron, M., Leckie, R. M., Petrizzo, M. R., Soldan, D., and Verga, D., 2009, Paraticinella n. gen. and taxonomic revision of Ticinella bejaouaensis Sigal, 1966: Journal of Foraminiferal Research, v. 39, p. 126-137.

—, and Sliter, W. V., 1999, Cretaceous paleoceanography: evidence from planktic foraminiferal evolution, in Barrera, E., and Johnson, C. C. (eds.), Evolution of the Cretaceous Ocean-Climate System. Geological Society of America, Special Paper 332, p. 301-328.

, and Verga, D., 2004, Practical Manual of Cretaceous Planktonic Foraminifera, International School on Planktonic Foraminifera, 3rd Course: Cretaceous. in Verga, D., and Rettori, R. (eds.), Universities of Pergia and Milan, Tipografia Pontefelcino, Perugia, Milan, Italy, 283 p.

Randrianasolo, A., and Anglada, R., 1998, About Ticinella roberti var. bejaouaensis Sigal 1966 and Ticinella bejaouaensis Sigal emended Moullade 1966, in Joint Regional Meeting of IGCP Projects nos. 381 and 362, held in conjunction with the Cuban Geological Congress, Havana, Cuba, 24 March-1 April 1998: Geologia y Mineira '98, Memorias, La Habana, v. 2, p. 298.

Reichel, M., 1950, Observations sur les Globotruncana du gisement de la Breggia (Tessin): Eclogae Geologicae Helvetiae, v. 42, p. $596-617$.
Renz, O., Luterbacher, H., and Schneider, A., 1963, Stratigraphischepaląontologische untersuchungen im Albien und Cenomanien des Neuenburger Jura: Eclogae Geologicae Helvetiae, v. 56, p. 1076-1116.

RisCH, H., 1969, Stratigraphie der höheren Unterkreide der bayerischen Kalkalpen mit Hilfe von Mikrofossilien, Dissertation, Ludwig-Maximilian Universität, München, 180 p.

RobAszYnSKi, F., and CARON, M. (COORDinATORS)., 1979, Atlas of Mid-Cretaceous Planktic Foraminifera (Boreal Sea and Tethys): Cahiers de Micropaléontologie, v. 1, 185 p.

, and $\longrightarrow$ 1995, Foraminifères planktoniques du Crétacé: commentaire de la zonation Europe-Mediterranée: Société Géologique de France, v. 166, p. 681-692.

Roth, P. H., 1978, Cretaceous nannoplankton biostratigraphy and oceanography of the northwestern Atlantic Ocean, in Benson, W. E., Sheridan, R. E., and others. (eds.), Initial Reports of the Deep Sea Drilling Project: U.S. Government Printing Office, Washington, D.C., v. 44, p. 731-760.

Sigal, J., 1966, Contribution á une monographie des Rosalines. I. Le genre Ticinella Reichel, souche des Rotalipores: Eclogae Geologicae Helvetiae, v. 59, p. 185-217.

_, 1977 , Essai de zonation du Crétacé méditerranéen à l'aide des foraminifères planctoniques: Geologie Mediterraneenne, v. 4, p. 99-108.

SiKorA, P. J., and OlsSOn, R. K., 1991, A paleoslope model of the late Albian to early Turonian foraminifera of the western Atlantic margin and North Atlantic basin: Marine Micropaleontology, v. 18, p. $15-72$.

SissingH, W., 1977, Biostratigraphy of Cretaceous calcareous nannoplankton: Geologie en Mijnbouw, v. 56, p. 37-50.

SLITER, W. V., 1989, Biostratigraphic zonation for Cretaceous planktic foraminifers examined in thin section: Journal of Foraminiferal Research, v. 19, p. 1-19.

Steineck, P. L., and Fleisher, R. L., 1978, Towards the classical evolutionary reclassification of Cenozoic Globigerinacea (Foraminiferida): Journal of Paleontology, v. 52, p. 618-635.

TAKAYANAGI, Y., and IWAMOTO, H., 1962, Cretaceous planktic foraminifera from the middle Yezo Group of the Ikushumbetsu, Miruto, and Hatonosu areas, Hokkaido: Transactions and Proceedings of the Paleontological Society of Japan, New Series, v. 45 , p. 183-196.

TAPPAN, H., 1940, Foraminifera from the Grayson Formation of northern Texas: Journal of Paleontology, v. 14, p. 93-126.

Tornaghi, M. E., Premoli Silva, I., and Ripepe, M., 1989 Lithostratigraphy and planktonic foraminiferal biostratigraphy of the Aptian-Albian "Scisti a Fucoidi" in the Piobbico core, Marche, Italy: background for cyclostratigraphy: Rivista Italiana di Paleontologia e Stratigrafia, v. 95, p. 223-264.

VERGA, D., and , 2003, Early Cretaceous planktonic foraminifera from the Tethys: The large many-chambered representatives of the genus Globigerinelloides: Cretaceous Research, v. 24, p. 661-690.

Wagner, T., Herrle, J. O., Sinninghe, D., Schouten, S., Stüsser, I., and Hofmann, P., 2008, Rapid warming and salinity changes of Cretaceous surface waters in the subtropical North Atlantic: Geology, v. 36, p. 203-206. 